ROCZNIK PRZEMYSKI t. 57

HISTORIA z.1 (26) 2021

TOMASZ POMYKACZ (Przemyśl)

orcid.org/ 0000-0002-8368-0069

\title{
STRUKTURA NARODOWOŚCIOWA GARNIZONU TWIERDZY PRZEMYŚL W OKRESIE OD WRZEŚNIA 1914 DO MARCA 1915 ROKU - PRÓBA REKONSTRUKCJI
}

\author{
Abstract \\ The ethnic structure of the garrison of the Przemyśl Fortress between \\ SEPTEMBER 1914 AND MARCH 1915 - AN ATTEMPT AT RECONSTRUCTION
}

In this paper the author attempts to present the ethnic composition of the garrison of the Przemyśl Fortress between September 1914 and March 1915, among others based on statistical data of the whole monarchy and the ethnic makeup in the areas where military units fighting in Przemyśl were mobilized. The statistics have been supplemented with information from Austrian and Hungarian press (mainly from 1914-1915), diaries and memoirs as well as relevant literature.

Keywords: Przemyśl Fortress, ethnic structure, Austro-Hungarian Army, Austria-Hungary

Słowa kluczowe: Twierdza Przemyśl, struktura narodowościowa, armia austro-węgierska, Austro-Węgry

Jak dotąd w literaturze nie podjęto próby kompleksowego przedstawienia składu narodowościowego załogi Twierdzy Przemyśl w okresie od września 1914 do marca 1915 r. Nie jest to rzeczą łatwą, ponieważ nie ma pełnych i wyczerpujących danych co do składu garnizonu, jak i składu narodowościowego jednostek, które znajdowały się w twierdzy. Istnieje jednak szereg danych, pozwalających spróbować choćby w przybliżeniu zarysować udział poszczególnych narodowości Austro-Węgier w przemyskim garnizonie.

Na początku I oblężenia, w drugiej połowie września 1914 r., w twierdzy znajdowały się pochodzące z Węgier k.węg. 23 Dywizja Piechoty Honwedu, k.węg. 6 i 16 Pułk Marszowy Honwedu, k.węg. 97 Brygada Pospolitego Ruszenia, przedlitawskie c.k. 93, 108 i 111 Brygady Pospolitego Ruszenia, batalion marszowy c.k. 35 Pułku Piechoty Landwehry, pięć kompanii zapasowych pospolitego ruszenia, dwa 
bataliony c.k. 34 Pułku Pospolitego Ruszenia, cztery bataliony grupy gen. Wilhelma Nickla - w sumie $65^{1 / 2} 2$ batalionu, ponadto siedem szwadronów jazdy, k.węg. 2 Pułk Armat Polowych Honwedu, 43 kompanie artylerii fortecznej, 48 (lub 491) oddziałów artylerii pospolitego ruszenia, osiem kompanii saperów oraz oddziały robocze, liczne instytucje i zakłady stanowiące zaplecze twierdzy ${ }^{2}$. Pomiędzy I a II oblężeniem rozwiązano k.węg. 6 Pułk Marszowy Honwedu, którego żołnierzami uzupełniono straty w pułkach 23 dywizji, ponadto do załogi twierdzy przydzielono austriacką c.k. 85 Brygadę Piechoty Landwehry, tak że liczba batalionów piechoty wzrosła do ok. $68^{1} 2^{3}$. W sumie na początku I oblężenia $1914 \mathrm{r}$. liczebność załogi twierdzy według różnych danych i szacunków oscylowała wokół 130000 żołnierzy i oficerów ${ }^{4}$, a na początku drugiego oblężenia stan załogi obliczano na 130767 ludzi ${ }^{5}$.

W odniesieniu do składu narodowościowego załogi twierdzy w literaturze okresu międzywojennego (mającej w dużej mierze walor źródłowy), w spotykamy jedynie ogólnikowe określenia, wskazujące, iż większość stanowili żołnierze węgierscy i rusińscy (ukraińscy), z niewielkim udziałem Niemców ${ }^{6}$, lub że $60 \%$ (a nawet $75 \%{ }^{7}$ ) załogi stanowili Węgrzy ${ }^{8}$. Dezső Nónay, w czasie walk o Przemyśl dowodzący k.węg. 5 Pułkiem Piechoty Honwedu, w odniesieniu do sytuacji z okresu I oblężenia pisał, że na $651 \frac{1}{2}$ batalionów, które znajdowały się w twierdzy 36 bataliony należały do Honwedu lub węgierskiego pospolitego ruszenia, resztę stanowiło 191/2 batalionów ukraińskojęzycznych, pięć - niemieckojęzycznych, pięć

${ }^{1}$ B. Geöcze, A przemysli tragédia, Budapest 1922, załącznik nr 1; F. Conrad v. Hötzendorf, Aus meiner Dienstzeit 1906-1918, 5. Bd., Oktober-November-Dezember 1914: die Kriegsereignisse und die politischen Vorgänge in dieser Zeit, Wien 1925, załącznik D.

${ }^{2}$ Österreich-Ungarns letzter Krieg, 1. Bd., Das Kriegsjahr 1914: Vom Kriegsausbruch bis zum Ausgang der Schlacht bei Limanowa-Łapanów, hrsg. E. Glaise-Horstenau, 2. Aufl., Wien 1931, (dalej: ÖULK, 1), s. 379; W. Gorgosz, Oblężenie i obrona Przemyśla w r. 1914/1915, Odbitka z „Bellony” t. 41, Warszawa 1933, tabl. II; B. Geöcze, op. cit., załącznik nr 1.

${ }^{3}$ B. Geöcze, op. cit., załącznik nr 1.

${ }^{4}$ F. Forstner, Twierdza Przemyśl, Warszawa 2000, s. 109.

${ }^{5}$ F. Stuckheil, Drugie oblężenie Twierdzy Przemyśl, cz. 2, Czasy upadku, Przemyśl 2004, s. 15.

${ }^{6}$ ÖULK, 1, s. 379.

${ }^{7}$ K. Aggházy, S. Valér, A világháború: 1914-1918, Budapest 1934, s. 148.

${ }^{8}$ K. Révy, Przemysl feladata és szerepe 1915. márc. 22-ig, „Magyar Katonai Közlöny“, R. 8, nr 6 (1920), s. 381; idem, Tamásy Árpád táborszernagy 1861-1939, „Magyar Katonai Szemle“, R. 9, 3 (1939), s. 238 (autor obydwu tekstów walczył w Twierdzy Przemyśl jako oficier sztabowy k.węg. 23 Dywizji Piechoty Honwedu; podał, że 60\% załogi stanowili żołnierze Honwedu); A világháború története, szerk. J. Pilch, Budapest [1928], s. 112; O. Firbás, Przemyśl szegedi védői [I], „Szegedi Szemle", R. 3, nr 9 (83) z 27 marca 1930, s. 4; D. Molnár, Limanova: magyar gyözelem, Budapest 1932, s. 487. Prawnik z Egeru Kálmán Molnár, służący w twierdzy w k.węg. 5 Pułku Piechoty Honwedu i będący zarazem redaktorem wydawanej w Przemyślu od 4 października 1914 do 21 marca 1915 r. gazety „Tábori Ujság“ podawał, że w twierdzy przebywało „więcej niż pięćdziesiąt tysięcy Węgrów“, zob. K. Molnár, Magyar élet és magyar irodalom Przemyslben 1914-1915 [I. rész], „Egri Népujság“, R. 41, nr 49 z 28 lutego 1924 r., s. 2. Beata Świętojańska liczbę żołnierzy narodowości węgierskiej w czasie walk o Twierdzę Przemyśl oszacowała na około 35-40 tysięcy, nie podała jednak, na podstawie jakich danych uzyskano ten szacunek lub skąd ta informacja została zaczerpnięta, zob. B. Swiętojańska, Miasto Przemyśl garnizonem armii austro-węgierskiej w okresie autonomii galicyjskiej, „Rocznik Przemyski“, R. 40 (2004), z. 4 Historia, s. 32. 
polsko- i ukraińskojęzycznych, należących do jednostek austriackiego pospolitego ruszenia bądź Landwehry9 . Podobne, ogólnikowe w sumie dane, spotykamy w późniejszych opracowaniach. W wydanej w 1940 r. pracy Hermanna Heidena Bollwerk am San: Schicksal der Festung Przemysl (wyd. polskie 2013), określono, że u progu I oblężenia w Twierdzy Przemyśl na 40 batalionów pospolitego ruszenia 19 składało się z Rusinów ${ }^{10}$. Niemalże identyczne dane zawarte zostały w pochodzącej 1987 r. pracy Franza Forstnera Przemyśl: Österreich-Ungarns bedeutendste Festung (wyd. polskie 2000), gdzie proporcje te określono jako 191/2 batalionów żołnierzy rusińskich na $40 \frac{1}{2}$ batalionów pospolitego ruszenia znajdujących się w twierdzy pod koniec września 1914 r. ${ }^{11}$ Wydane w ostatnich latach prace Graydona A. Thunstalla ${ }^{12}$ oraz Alexandra Watsona ${ }^{13}$ nie zmieniają w istotny sposób zarysowanego wyżej ogólnego obrazu.

Otwarta pozostaje więc kwestia, na ile przedstawione powyżej dane można zweryfikować bądź uszczegółowić.

Wspomniany brak źródeł wymusił określoną metodę badawczą. Podstawowym opracowaniem wykorzystanym przy pisaniu całego niniejszego artykułu jest praca Maximiliana Ehnla Die österreichisch-ungarische Landmacht nach Aufbau, Gliederung, Friedensgarnison, Einteilung und nationaler Zusammensetzung im Sommer 1914, stanowiąca uzupełniający zeszyt do wielotomowego wydawnictwa Österreich-Ungarns letzter Krieg. Ehnl przyjął 28 czerwca 1914 r. jako moment aktualności prezentowanych danych ${ }^{14}$, a więc dzień przypadający na okres przed mobilizacją armii austro-węgierskiej w lipcu i sierpniu $1914 \mathrm{r}$. W związku z tym nie jest to obraz struktury językowej jednostek, które latem 1914 r. ruszyły na front. Co więcej, nie podał on struktury językowej jednostek pospolitego ruszenia (co wynikało z faktu, że jednostki te tworzono dopiero po ogłoszeniu mobilizacji), które przeważały wśród oddziałów piechoty garnizonu Twierdzy Przemyśl. Dlatego prezentując dane dla jednostek pospolitego ruszenia przyjęto założenie, że w dużej mierze korespondują one z danymi dla przedstawionych przez Ehnla jednostek obrony krajowej, bowiem były one uzupełniane w tych samych okręgach i jeśli chodzi o kwestie demograficzne, to różnica między obydwoma rodzajami tych wojsk polegała przede wszystkim na strukturze wiekowej służących w nich żołnierzy: do pospolitego ruszenia powoływano starsze roczniki i na początku wojny byli to mężczyźni w wieku 33-42 lata ${ }^{15}$.

\footnotetext{
${ }^{9}$ D. Nónay, A volt m. kir. szegedi 5. honvéd gyalogezred a világháborúban, Szeged 1931, s. 64.

${ }^{10}$ H. Heiden, Bastion nad Sanem: losy Twierdzy Przemyśl, Oświęcim 2013, s. 48.

${ }^{11}$ F. Forstner, op. cit., s. 109.

${ }^{12}$ G. A. Thunstall, Written in blood: the battles for Fortress Przemyśl, Bloomington \& Indianapolis 2016, s. 29.

${ }^{13}$ A. Watson, The fortress: the great siege of Przemyśl, London 2019, s. 69-71.

${ }^{14} \mathrm{M}$. Ehnl, Die österreichisch-ungarische Landmacht nach Aufbau, Gliederung, Friedensgarnison, Einteilung und nationaler Zusammensetzung im Sommer 1914, Wien 1934, s. 4.

${ }^{15}$ ÖULK, 1, s. 80; A. Płomieńczyk [pseud.], Armja austro-węgierska, Warszawa 1916, s. 3.
} 
Drugim założeniem przyjętym przy prezentacji struktury narodowościowej służących w Twierdzy Przemyśl jest to, że w przypadku poszczególnych jednostek (zwłaszcza piechoty) ich silne powiązanie z określonym terytorium sprawiało, że w ich składzie narodowościowym znajdowała odzwierciedlenie struktura etniczna obszaru, w którym były one uzupełniane. To sprawiło, że dane dla struktury językowej zaczerpnięte z opracowania Ehnla zestawiono z wynikami spisu powszechnego z 31 grudnia 1910 r. dla obszarów uzupełnień poszczególnych jednostek.

Granice okręgów uzupełnień poszczególnych jednostek przedlitawskich opracowano na podstawie informacji zawartych w Organische Bestimmungen für die k.k. Landwehr- (Landesschützen-) Ergänzungsbezirkskommandos i Organische Bestimmungen für die k.k. Landsturmbezirkskommandos („Normalverodnungsblatt für das k.u.k. Heer”, 5. Stück vom 1 Februar 1913) oraz w oparciu o mapy dołączone do następujących wydawnictw: Schematismus der k.k. Landwehr und der k.k. Gendarmerie der Im Reichsrate Vertretenen Königreiche und Länder für 1912, Wien 1912 oraz Schematismus der k.k. Landwehr und der k.k. Gendarmerie der Im Reichsrate Vertretenen Königreiche und Länder für 1913, Wien 1913. Granice okręgów uzupełnień jednostek Honwedu oraz węgierskiego pospolitego ruszenia ustalono na podstawie danych w Übersicht der Aufteilung der Länder der heiligen Krone Ungarns in Landsturmkommandobereiche (,Normalverordnungblatt für das k.u.k. Heer”, 32. Stück, vom 4 Juli 1914) oraz map A magyar királyi Honvédség elhelyezési térképe, Budapest [1910?], pochodzących ze zbiorów Hadtörténeti Intézet és Múzeum w Budapeszcie (sygn. B IX c 764) i udostępnianych przez portal Hungaricana ${ }^{16}$. W obydwu przypadkach na mapach przedstawiających granice okręgów mobilizacyjnych zarysowane są też granice jednostek administracji cywilnej (powiatów w przypadku Przedlitawii i komitatów oraz powiatów w przypadku Zalitawii), co pozwoliło dokładnie ustalić strukturę narodowościową i językową obszarów mobilizacyjnych poszczególnych oddziałów.

W przypadku okręgów mobilizacyjnych armii wspólnej, w których mobilizowane były oddziały robocze, wykorzystano dane z Heeres- (Marine-) Ergänzungs-Bezirks-Eintheilung, („Verordnungsblatt für das k.k. Heer. Normal-Verordnungen”, 49. Stück vom 21. Dezember 1882).

Pomocne przy ustalaniu okręgów mobilizacyjnych niektórych jednostek było odwołanie się do danych zawartych w „Listach Strat”. Były to oficjalne zestawienia poległych, zmarłych z ran, rannych, zaginionych i wziętych do niewoli, układane na podstawie danych przesyłanych przez dowództwa poszczególnych jednostek. Dane te podawano wedle schematu: ,imię i nazwisko, stopień wojskowy, oddział wojska, pododdział, posiada prawo swojszczyzny w kraju, powiecie, w miejscowości, rok urodzenia, wiadomość”. „Prawo swojszczyzny” oznaczało przynależność

\footnotetext{
${ }^{16} \mathrm{https}: / /$ maps.hungaricana.hu/hu/HTITerkeptar/2663/?list=eyJxdWVyeSI6ICJISUVSPShIVElI aWVyYXJjaHktMTgpIn0 [dostęp 25 kwietnia 2021]. Dalej: A magyar királyi Honvédség elhelyezési térképe, [1910?].
} 
do określonej gminy. Dziedziczyło się je po ślubnym ojcu lub, w razie jego braku, po matce. Prawo to było niezależne od stanu faktycznego - można było przynależeć do określonej gminy przebywając poza jej obrębem ${ }^{17}$. Bardziej więc informowało ono o pochodzeniu rodzica danej osoby niż jej samej ${ }^{18}$, tym niemniej przy dużej próbie (dane zaczerpnięte $\mathrm{w}$ niniejszym artykule pochodzą z wszystkich 709 numerów „List Strat”19) na podstawie najczęściej powtarzających się informacji dotyczących pochodzenia żołnierzy można ustalić, na jakich terenach konkretna jednostka była uzupełniana. Mimo sporej ilości błędów i pomyłek „Listy Strat” dostarczają wartościowego materiału ilustracyjnego i statystycznego. W przypadku Węgier należy zaznaczyć, że zamiast powiatu podawano z reguły komitat, który był tradycyjną na Węgrzech jednostką administracyjną, nieznaną w Przedlitawii i obejmującą kilka powiatów, dopiero w dalszej kolejności dzielącą się na gminy.

W miarę możliwości uzyskane w przedstawiony wyżej sposób dane uzupełniono o informacje z wydawnictw źródłowych i prasy z epoki, opracowań, literatury oraz dzienników i pamiętników.

Skład jednostek tworzących garnizon Twierdzy Przemyśl ustalono w oparciu zestawienia jednostek zawarte w pracach A przemysli trágédia Bertalana Geőczego ${ }^{20}$, Oblężenie i obrona Przemyśla w r. 1914/1915 Witolda Gorgosza ${ }^{21}$ oraz przechowywany w Kriegsarchiv w Wiedniu, wytworzony w c. i k. Naczelnym Dowództwie Armii (k.u.k. Armeeoberkommando; dalej: AOK) dokument Kriegsgliederung der Besatzung von Przemyśl zur Zeit der 2. Einschließung ${ }^{22}$ (dalej: Kriegsgliederung der Besatzung...). Znamienne, że nie we wszystkich punktach (szczególnie w przypadku mniejszych jednostek) informacje w tych materiałach są ze sobą zbieżne (co sygnalizowano w konkretnych przypadkach), aczkolwiek wszystkie te materiały mają charakter źródłowy, bowiem zostały napisane albo przez uczestnika walk o twierdzę (Geőcze), albo w oparciu o źródła i niemieckojęzyczną literaturę dotyczącą tematu,

${ }^{17}$ K. Grzybowski, Historia państwa i prawa Polski, t. 4: Od uwłaszczenia do odrodzenia państwa, Warszawa 1982, s. 307.

${ }^{18}$ Znakomitą ilustracją zamieszania, jaki ten system wprowadzał były losy braci Alojzego i Józefa Trojanowskich, którzy urodzili się w Przemyślu i w czasie, gdy był on oblegany, udali się do Tata-Tóváros na Węgrzech, gdzie ulokowany był punkt mobilizacyjny uzupełnień dla przemyskiego c.k. 18 Pułku Pospolitego Ruszenia. Okazało się, że Trojanowscy po ojcu, pochodzącym z Łopatyna, odziedziczyli przynależność do tamtejszej gminy, która leżała w okręgu mobilizacyjnym c.k. 35 Pułku Landwehry ze Złoczowa. W związku z tym musieli udać się do punktu uzupełnień pułku mobilizowanego w gminie, do której prawnie należeli. Ponieważ Złoczów był zajęty przez Rosjan, musieli najpierw udać się do Igló, później zaś do Knittenfeld, by ostatecznie wrócić do Tata-Tóváros, zob. A. Trojanowski, Żotnierskie pamiętniki 1914-1918, na podstawie zapisków ustnych i przekazów opracował Władysław Trojanowski, msps udostępniony przez Martę Trojanowską.

${ }^{19}$ „Verlustliste”, nr 1 z 12 sierpnia 1914 r., nr 709 z 14 stycznia [i. e. lutego] 1919 r.

${ }^{20}$ B. Geőcze, op. cit., załącznik nr 1.

${ }^{21} \mathrm{~W}$. Gorgosz, op. cit., tabl. II.

${ }^{22} \mathrm{~W}$ niniejszym artykule wykorzystano kopię tego dokumentu zawartą w opracowaniu: K. Tranmer, Przemyśl 1914-1915, Wien 2003, s. 19-20. Jest to wydany nakładem autora zbiór kopii dokumentów dotyczących walk o Twierdzę Przemyśl, głównie dotyczących działań poczty lotniczej. Opracowanie przechowywane jest w zbiorach Biblioteki Muzeum Narodowego Ziemi Przemyskiej w Przemyślu. 
częściowo niedostępną dla autora niniejszego artykułu (Gorgosz $\left.{ }^{23}\right)$, albo powstały w momencie walk o Przemyśl, jak Kriegsgliederung der Besatzung.... W przypadku tego ostatniego należy zaznaczyć, że zdarzają się w nim braki i pomyłki - nie ujęto w nim walczącego w Przemyślu c.k. 10 Pułku Pospolitego Ruszenia, w przypadku c.k. 34 Pułku Pospolitego Ruszenia w uwagach zaznaczono, że nie jest potwierdzona obecność jego trzech[!] batalionów w twierdzy, ujęto natomiast k.węg. 15 Pułk Marszowy Honwedu ${ }^{24}$; w przypadku tego i pozostałych pułków marszowych (k.węg. 3, 4 i 16 Pułku Marszowego Honwedu), zaznaczono, że nieznana jest liczba tworzących je batalionów. Jest to o tyle znamienne, iż świadczy, że przynajmniej w czasie powstania tego dokumentu, mimo stałego kontaktu z Komendą Twierdzy, AOK nie do końca było zorientowane w składzie garnizonu twierdzy. Jednakże mimo pomyłek, jest to bardzo cenne źródło, szczególnie z tego względu, że dzięki niemu można w największym zakresie ustalić skład i strukturę oddziałów roboczych służących w Twierdzy Przemyśl.

Nazwy jednostek w pierwszym użyciu przedstawiono w języku polskim, w każdym kolejnym zastosowano skrót odwołujący się do ich niemieckiej nazwy stosowanej przed 1917 r. (np. LIR - Landwehr Infanterie Regiment - pułk Obrony Krajowej, LstIR - Landsturm Infanterie Regiment - pułk pospolitego ruszenia) niezależnie od części monarchii, z której pochodziła dana jednostka. By tę kwestię sprecyzować, przed nazwą każdej zastosowano oficjalne (niemieckie) skróty, odwołujące się do umiejscowienia danej jednostki w strukturze sił zbrojnych Austro-Węgier: k.k. (kaiserlich-königlich - cesarsko-królewski) dla jednostek

${ }^{23}$ W. Gorgosz, op. cit., s. 35.

${ }^{24}$ Pułki marszowe były tworzone z rezerwistów, których liczba w czasie mobilizacji przekraczała możliwości przyjęcia ich przez istniejące już pułki. Każdy z 32 pułków Honwedu w chwili mobilizacji wystawiał sześć kompanii marszowych, co dawało 48 batalionów marszowych (numerowanych od 1 do 48), z których utworzono 16 pułków marszowych liczących trzy bataliony każdy. Pułki marszowe miały tylko jeden oddział karabinów maszynowych. Tak powstałe jednostki wysyłano na front i brały one udział w walkach, ale ich ostatecznym przeznaczeniem było uzupełnienie strat w pułkach macierzystych, zob. A magyar gyalogság. A magyar gyalogos katona története, szerk. J. Doromby, L. Reé, [Budapest 1939], s. [437]. K.węg. 15 Pułk Marszowy Honwedu przebywał w Twierdzy Przemyśl od 6 do 12 września 1914 r. Składał się z 3, 4 i 47 batalionu marszowego. Utworzony był na bazie k.węg. 3 (Debrecen) i k.węg. 4 (Nagyvárad) Pułku Piechoty Honwedu. Wchodził w skład 39 Brygady Piechoty Honwedu i 41 Dywizji Piechoty Honwedu. W momencie wybuchu wojny wchodził w skład 2 Armii jako jedna z formacji marszowych k.węg. 20 Dywizji Piechoty Honwedu (k.u 20 LITD). Po ogłoszeniu pułk sformowano w Berettyóújfalu. Jego dowódcą został podpułkownik Árpád Jancsó z k.węg. 4 Pułku Piechoty Honwedu. W dniach 2-3 września pułk opuścił Berettyóújfalu, 4 września dotarł do Sianek, 6 września przez Sambor do Przemyśla. Rozlokowano go we wsiach Sielec i Krówniki. W związku z odwrotem armii austro-węgierskiej za San 10 września 3 Batalion Marszowy (mjr Jenő Balla) odesłano do Jarosławia, dla obrony znajdujących się tam przepraw przez San. 11 września w tym samym celu wysłano do Radymna 47 batalion marszowy (mjr Ernő Szábó), 12 września do Jarosławia wysłano też stacjonujący dotąd w okolicy fortu XIV „Hurko” 4 batalion marszowy (mjr Kálmán Leöchely). W ostatniej dekadzie września pułk dotarł w okolice Laborcfó (dziś Habura w północno-wschodniej Słowacji), gdzie został rozwiązany, a jego oficerami i żołnierzami uzupełniono straty w pułkach k.u. 20 LITD, zob. ÖULK, 1, s. 73; Négyes honvédek fegyverben, [Békéscsaba 1934], s. 18, 19, 30, 51-54; Debreceni honvédek harcban, I. rész, A m. kir. debreceni 3. honvéd gyalogezred harcai az oroszokkal az olasz hadüzenetig, összeall. J. Molnár, Debrecen 1926, s. 67-69; A volt. m. kir. nagyváradi 4. honvéd gyalogezred és népfelkelö alakulatai bajtársi szövetségnének értesitője (összeáll.) K. Kratochwil, [S.1.] 1933, s. 7. 
austriackich (przedlitawskich), k.u. (königlich ungarisch - królewsko-węgierski ${ }^{25}$ ) dla jednostek węgierskich, k.u.k. (kaiserlich und königlich - cesarski i królewski) w przypadku jednostek należących do armii wspólnej.

Naturalnym punktem wyjścia przy omawianiu podjętego tu zagadnienia jest stwierdzenie, że wielonarodowościowy skład monarchii siłą rzeczy wpływał na skład narodowościowy jej sił zbrojnych.

Wg spisu z 1910 r. udział procentowy poszczególnych narodowości wśród prawie 49 milionów ogółu mieszkańców całej monarchii przedostawał się następująco:

Tabela 1. Struktura językowa Austro-Węgier wg spisu z 1910 r.

\begin{tabular}{|l|c|c|c|c|c|c|}
\hline & \multicolumn{2}{|c|}{ Austria $^{26}$} & \multicolumn{2}{c|}{$\begin{array}{c}\text { Królestwo } \\
\text { Węgierskie }\end{array}$} & \multicolumn{2}{c|}{ Austro-Węgry } \\
\hline niemiecki & 9950266 & $35,6 \%$ & 2037435 & $9,8 \%$ & 11987701 & $24,5 \%$ \\
\hline węgierski & 10974 & $0,04 \%$ & 10050575 & $48,1 \%$ & 10061549 & $20,6 \%$ \\
\hline czeski & 6435983 & $23,02 \%$ & - & - & 6435983 & $13,2 \%$ \\
\hline słowacki & - & - & 1967970 & $9,4 \%$ & 1967970 & $4 \%$ \\
\hline polski & 4967984 & $17,8 \%$ & - & - & 4967984 & $10,2 \%$ \\
\hline rumuński & 275115 & $1 \%$ & 2949032 & $14,1 \%$ & 3224147 & $6,6 \%$ \\
\hline ukraiński & 3518854 & $12,6 \%$ & 472587 & $2,3 \%$ & 3991441 & $8,1 \%$ \\
\hline serbochorwacki & 783334 & $2,8 \%$ & - & - & 783334 & \\
\hline chorwacki & - & - & 1833162 & $8,8 \%$ & 1833162 & \multirow{2}{*}{$7,6 \%$} \\
\hline serbski & - & - & 1106471 & $5,2 \%$ & 1106471 & \\
\hline słoweński & 1252940 & $4,5 \%$ & - & - & 1252940 & $2,6 \%$ \\
\hline włoski & 768422 & $2,7 \%$ & - & - & 768422 & $1,6 \%$ \\
\hline inny & - & - & 469255 & $2,2 \%$ & 469255 & $1 \%$ \\
\hline & 27963872 & $100 \%$ & 20886487 & $100 \%$ & 48850359 & $100 \%$ \\
\hline
\end{tabular}

Źródło: Die Ergebnisse der Volkszählung vom 31. Dezember 1910 in der Im Reichsrate Vertretenen Königreichen und Länder. 1. Heft, Die summarischen Ergebnisse der Volkszählung, Wien 1912, s. 59*; A Magyar Szent Korona Országainak 1910. évi népszámlása. 1. rész, A népesség föbb adatai. Községek és népesebb puszták, telepek szerint, Budapest 1912, s. 5-6*. W austriackim opracowaniu uwzględnione języki niemiecki, węgierski, czeski-morawski-słowacki, polski, rumuński, ukraiński, serbsko-chorwacki, słoweński i włoski-ladeński, w węgierskim węgierski, niemiecki, słowacki, rumuński, ukraiński, chorwacki, serbski i inny.

Ten skład narodowościowy państwa w dużej mierze znajdował odzwierciedlenie w ogólnym udziale poszczególnych narodowości w całej armii, w której w 1910 r.

\footnotetext{
${ }^{25} \mathrm{~W}$ literaturze polskiej dominuje forma „królewsko-węgierski” choć bardziej poprawne (i logiczne) wydaje się thumaczenie „królewski węgierski”.

${ }^{26}$ Oficjalna nazwa zachodniej części monarchii do 1915 r. brzmiała Królestwa i Kraje w Radzie Państwa Reprezentowane (Im Reichsrate Vertretenen Königreichen und Länder).
} 
na 100 żołnierzy 25 było narodowości niemieckiej, 23 węgierskiej, 13 czeskiej, 9 chorwackiej lub serbskiej, 8 polskiej, 8 ukraińskiej, 7 rumuńskiej, 4 słowackiej i morawskiej, 2 słoweńskiej i 1 włoskiej ${ }^{27}$.

Drugim istotnym czynnikiem wpływającym na skład narodowościowy załogi Twierdzy Przemyśl był rodzaj i pochodzenie jednostek, które w niej służyły.

Organizacja sił zbrojnych Austro-Węgier odzwierciedlała złożony, dualistyczny charakter monarchii. Ugoda z 1867 r. zawarta została między dwoma równorzędnymi partnerami, z których każdy uznał (lub - jak w przypadku Wiednia - był zmuszony uznać), że przy respektowaniu wewnętrznej niezależności obu członów państwa, istnieją pewne obszary wspólne, do których zaliczono politykę zagraniczną i obronność oraz dotyczące ich kwestie finansowe. Konkretne kwoty, potrzebne na pokrycie wydatków dotyczących całej monarchii, były co roku uzgadniane przed delegacje parlamentów węgierskiego i austriackiego. W odniesieniu do spraw wojskowych wydatki ustalane pomiędzy delegacjami były przeznaczone dla armii wspólnej, obejmującej wszystkie rodzaje sił zbrojnych. Ta część austro-węgierskich sił zbrojnych określana była do 1889 r. jako c.k. - cesarsko-królewskie. W 1889 r. pod naciskiem Węgrów, uzależniających od uznania ich żądań poparcie dla nowej ustawy wojskowej, nazwę tę zmieniono na c. i k. - cesarskie i królewskie, co miało podkreślić równorzędność obu członów monarchiii ${ }^{28}$.

Oprócz tego integralną częścią sił zbrojnych Austro-Węgier były formacje obrony krajowej, których budżety uchwalane były w parlamentach obu części monarchii i które organizacyjnie podlegały funkcjonującym w obu członach monarchii ministerstwom obrony krajowej: Landesverteidigungsministerium w Austrii (Przedlitawii) oraz Honvédelmi Minisztérium w Królestwie Węgierskim (Zalitawii) ${ }^{29}$. Odpowiednio jednostki te nosiły nazwę kaiserlich-königlich Landwehr (cesarsko-królewska Obrona Krajowa, potocznie określana jako Landwehra) oraz magyar királyi Honvédség (królewsko-węgierska Obrona Krajowa, potocznie określana jako Honwed). W przypadku jednostek piechoty były to formacje o niezależnej numeracji, toteż w obydwu częściach monarchii istniały pułki obrony krajowej o tych samych numerach, przy czym w Przedlitawii było ich 37, w Zalitawii 32. Do pewnego momentu zresztą numeracja ta pokrywała się z numerami pułków piechoty armii wspólnej, których było 102 .

W momencie powstania obrona krajowa pomyślana była jako formacja drugiej linii, mająca za zadanie wspieranie jednostek armii wspólnej, uważanych za jednostki pierwszoliniowe. W miarę upływu czasu, przede wszystkim pod naciskiem Węgrów, którzy z Honwedu chcieli uczynić formację możliwie w największy

${ }^{27}$ ÖULK, 1, s. 44, przyp. 1; T. Balla, A militarista birodalom mitosza: az osztrák-magyar haderő az első világháború elöestéjén, „Hadtorténelmi Közlemének”, R. 127, nr 3 (2014), s. 629.

${ }^{28}$ F. Conrad v. Hötzendorf, Aus meiner Dienstzeit 1906-1918, 1. Bd., Die Zeit der Annexionskrise 1906-1909, Wien 1921, s. 283; G. Kolmer, Parlament und Verfassung in Österreich, Vol. 4, 1885-1891, Wien-Leipzig 1907, s. 81.

${ }^{29}$ F. Conrad v. Hötzendorf, Aus meiner Dienstzeit 1906-1918, 1. Bd., s. 283. 
sposób spełniającą rolę armii narodowej i dążyli do przekształcenia jej w formację równorzędną z jednostkami armii wspólnej, ostatecznie przed wybuchem I wojny światowej doszło do zrównania rangi Honwedu (a w konsekwencji także Landwehry) z armią wspólną. Na początku wieku różnica polegała jedynie na krótszym - dwuletnim - okresie służby zasadniczej w obronie krajowej (w przypadku piechoty), w porównaniu z trzyletnim (do 1912 r.) okresem służby w armii wspólnej ${ }^{30}$. Po tym, gdy obrona krajowa została podniesiona do rangi formacji pierwszoliniowej, rolę jednostek drugiej linii w przypadku wybuchu wojny miały przejąć oddziały pospolitego ruszenia (niem. Landsturm, węg. Népfelkelés). Były one tworzone w obrębie tych samych okręgów i noszące ten sam numer, co odpowiednie jednostki obrony krajowej ${ }^{31}$ (w obrębie armii wspólnej nie tworzono jednostek pospolitego ruszenia). Jak już wspomniano, wcielano do nich rezerwistów starszych roczników, poza tym z reguły wyposażano je w starsze uzbrojenie i umundurowanie. Ponadto bataliony pospolitego ruszenia pozbawione były broni maszynowej. Bataliony obrony krajowej i pospolitego ruszenia liczyły po mobilizacji nieco ponad 1000 żołnierzy i oficerów.

W austro-węgierskiej doktrynie wojennej służącym w twierdzach pierścieniowych jednostkom piechoty stawiano dwojakie zadania: po pierwsze obrony biernej - obsadę fortów i umocnień pierścienia, po drugie obrony czynnej, rozumianej jako przeprowadzanie wypadów z twierdzy. Pierwsze zadania przeznaczano jednostkom pospolitego ruszenia, drugie formacjom pierwszej linii - armii wspólnej bądź obrony krajowej ${ }^{32}$. Zrąb jednostek piechoty załogi Twierdzy Przemyśl w okresie od września 1914 r. do marca 1915 r. stanowiły przede wszystkim jednostki pospolitego ruszenia, w drugim zaś rzędzie obrony krajowej.

W czasie I oblężenia w Twierdzy Przemyśl z jednostek przedlitawskich znalazły się:

c.k. 93 Brygada Pospolitego Ruszenia (k.k. 93 LstIBrig): c.k. 10 Pułk Pospolitego Ruszenia (k.k. 10 LstIR), c.k. 35 Pułk Pospolitego Ruszenia (k.k. 35 LstIR); c.k. 108 Brygada Pospolitego Ruszenia (k.k. 108 LstIBrig): c.k. 21 Pułk Pospolitego Ruszenia (k.k. 21 LstIR), c.k. Pułk Pospolitego Ruszenia Strzelców Krajowych nr II (k.k. LstLdschR Nr. II);

${ }^{30}$ T. Papp, A magyar Honvédség megalakulása a kiegyezés után, I. rész, „Hadtörténelmi Közlemények", R. 14, nr 2 (1967), s. 322; T. Nowakowski, Armia austro-węgierska 1909-1918, Warszawa 1992, s. 8; M. Baczkowski, Pod czarno-żóttymi sztandarami: Galicja i jej mieszkańcy wobec austro-węgierskich struktur militarnych 1868-1914, Kraków 2003, s. 19; T. Balla, op. cit., s. 628-629.

${ }^{31}$ Złożoność numeracji jednostek obrony krajowej i pospolitego ruszenia jednostek obu części monarchii można zobrazować chociażby na przykładzie pułków służących w Przemyślu. W czasie drugiego oblężenia służył tu c.k. 35 Pułk Landwehry oraz c.k. 35 Pułk Pospolitego Ruszenia obydwa pułki mobilizowane były w tym samym okręgu (Złoczów). Do tego dochodził batalion marszowy c.k. 35 Pułku Piechoty Landwehry. Drugim charakterystycznym przykładem są c.k. 10 Pułk Pospolitego Ruszenia oraz k.węg. 10 Pułk Pospolitego Ruszenia. Pierwszy mobilizowany był w okręgu Jungbunzlau (Mladá Boleslav) w Czechach, drugi w okręgu miszkolckim na Węgrzech.

${ }^{32}$ B. Geöcze, op. cit., s. 19. 
c.k. 111 Brygada Pospolitego Ruszenia (k.k. 111 LstIBrig): c.k. 17 Pułk Pospolitego Ruszenia (k.k. 17 LstIR), c.k. 18 Pułk Pospolitego Ruszenia (k.k. 18 LstIR), c.k. 33 Pułk Pospolitego Ruszenia (k.k. 33 LstIR).

Standardowo wszystkie te jednostki miały po trzy bataliony, z wyjątkiem k.k. 35 LstIR, który liczył cztery bataliony ${ }^{33}$.

Ponadto w twierdzy w tym czasie znalazły się dwa bataliony z c.k. 34 Pułku Pospolitego Ruszenia (k.k. 34 LstIR). Jedyną jednostką austriackiej obrony krajowej w tym czasie w Przemyślu był batalion marszowy c.k. 35 Pułku Piechoty Landwehry (k.k. 35 LMarschB). Jednostki te pozostały w Przemyślu także w czasie II oblężenia. Pomiędzy I a II oblężeniem do Twierdzy Przemyśl skierowano c.k. 85 Brygadę Piechoty Landwehry (k.k. 85 LIBrig), w skład której wchodziły c.k. 19 i 35 Pułk Piechoty Landwehry (k.k. 19 LIR i k.k. 35 LIR).

Jak widać, w czasie walk o Przemyśl wśród jednostek przedlitawskich dominowały oddziały galicyjskie, ponadto były to pojedyncze formacje pochodzące z Czech, Tyrolu i Dolnej Austrii (po jednym pułku). Dla roku 1914 nie mamy danych dla jednostek pospolitego ruszenia, jednakże sporo o prawdopodobnym ich składzie narodowościowym mówią dane dla odpowiednich pułków piechoty Landwehry (k.k. LIR). W poniższej tabeli zestawiono dane z $1914 \mathrm{r}$. ze składem językowym terenów mobilizacyjnych poszczególnych pułków Landwehry wg danych ze spisu z 1910 r.:

Tabela 2. Struktura językowa okręgów uzupełnień jednostek austriackiej obrony krajowej i pospolitego ruszenia służących w Twierdzy Przemyśl.

\begin{tabular}{|c|c|c|}
\hline $\begin{array}{c}\text { Okręg mobilizacyjny pułku piechoty } \\
\text { austriackiej Obrony Krajowej (k.k. LIR) } \\
\text { oraz austriackiego pospolitego ruszenia } \\
\text { (k.k. LstIR) }\end{array}$ & \begin{tabular}{|} 
Struktura językowa \\
okręgu \\
mobilizacyjnego \\
wg danych \\
ze spisu z $1910 \mathrm{r}$.
\end{tabular} & $\begin{array}{l}\text { Struktura językowa } \\
\text { oddziałów k.k. LIR } \\
\text { w } 1914 \text { r. }\end{array}$ \\
\hline K.k. 10 LstIR (Jungbunzlau) & $56,1 \%$ - czeski & $95 \%$ - czeski \\
\hline $\begin{array}{l}\text { Północne Czechy, powiaty: Böhmisch } \\
\text { Brod, Böhmisch Leipa, Dauba, Deutsch } \\
\text { Gabel, Friedland, Gablonz, Jungbunzlau, } \\
\text { Kolin, Kuttenberg, Münchengrätz, Neu- } \\
\text { bydžov, Poděbrad, Reichenberg, Turnau }\end{array}$ & $43,8 \%$ - niemiecki & $5 \%-$ inny \\
\hline K.k. 17 LstIR (Rzeszów) & $98,7 \%-$ polski & $97 \%$ - polski, \\
\hline $\begin{array}{l}\text { Galicja, powiaty: Kolbuszowa, Mielec, } \\
\text { Ropczyce, Rzeszów, Strzyżów, Tarnobrzeg }\end{array}$ & $\begin{array}{l}0,8 \% \text { - ukraiński } \\
0,5 \% \text { - inny }\end{array}$ & $3 \%-$ inny \\
\hline
\end{tabular}

${ }^{33}$ Ibidem, załącznik nr 1; Wg Gorgosza 4 bataliony miał liczyć też c.k. 10 Pułk Pospolitego Ruszenia - w takim wypadku c.k. 93 Brygada Pospolitego Ruszenia liczyłaby 8 batalionów, zob. W. Gorgosz, op. cit., tabl. II. 


\begin{tabular}{|c|c|c|}
\hline $\begin{array}{l}\text { K.k. } 18 \text { LstIR (Przemyśl) } \\
\text { Galicja, powiaty: Brzozów, Dobromil, } \\
\text { Krosno, Lisko, Przemyśl, Sanok }\end{array}$ & $\begin{array}{l}56,8 \% \text { - polski } \\
42,2 \% \text { - ukraiński } \\
1 \% \text { - inny }\end{array}$ & $\begin{array}{l}47 \% \text { - ukraiński } \\
43 \% \text { - polski } \\
10 \% \text { - inny }\end{array}$ \\
\hline K.k. 19 LIR (Lwów) & $50,7 \%$ - ukraiński & 59\% - ukraiński \\
\hline $\begin{array}{l}\text { Galicja, powiaty: Bóbrka, Brzeżany, } \\
\text { Lwów, Podhajce, Przemyślany, Rohatyn, } \\
\text { Sokal, Żółkiew }\end{array}$ & $\begin{array}{l}47,9 \%-\text { polski } \\
1,4 \%-\text { inny }\end{array}$ & $\begin{array}{l}31 \% \text { - polski } \\
10 \% \text { - inny }\end{array}$ \\
\hline K.k. 21 LstIR (St. Pölten) & $99 \%-$ niemiecki & $98 \%$ - niemiecki \\
\hline $\begin{array}{l}\text { Dolna Austria, powiaty: Amstetten, } \\
\text { Gmünd, Horn, Krems, Lilenfeld, Melk, } \\
\text { Pöggstall, Scheibs, St. Pölten, Waidhofen } \\
\text { an der Thaya, Waidhofen an der Ybbs, } \\
\text { Zwettl }\end{array}$ & $1 \%$ - inny & $2 \%$ - inny \\
\hline K.k. 33 LstIR (Stryj) & $68,6 \%$ - ukraiński & $73 \%$ - ukraiński \\
\hline $\begin{array}{l}\text { Galicja, powiaty: Dolina, Drohobycz, } \\
\text { Kałusz, Sambor, Skole, Stary Sambor, } \\
\text { Stryj, Turka, Żydaczów }\end{array}$ & $\begin{array}{l}29,2 \%-\text { polski } \\
2,2 \%-\text { inny }\end{array}$ & $27 \%$ - inny \\
\hline K.k. 34 LstIR (Jarosław) & $56,3 \%-$ polski & $75 \%-$ polski \\
\hline $\begin{array}{l}\text { Galicja, powiaty: Cieszanów, Gródek Ja- } \\
\text { gielloński, Jarosław, Jaworów, Łańcut, } \\
\text { Mościska, Nisko, Przeworsk, Rawa Rus- } \\
\text { ka, Rudki }\end{array}$ & $\begin{array}{l}42,9 \% \text { - ukraiński } \\
0,8 \% \text { - inny }\end{array}$ & $25 \%$ - inny \\
\hline K.k. 35 LIR i k.k. 35 LstIR (Złoczów) & $55,2 \%$ - ukraiński & $68 \%$ - ukraiński \\
\hline $\begin{array}{l}\text { Galicja, powiaty: Brody, Kamionka Stru- } \\
\text { miłowa, Radziechów }{ }^{34} \text {, Skałat, Tarnopol, } \\
\text { Trembowla, Zbaraż, Zborów, Złoczów }\end{array}$ & $\begin{array}{l}43,8 \%-\text { polski } \\
1 \%-\text { inny }\end{array}$ & $\begin{array}{l}25 \%-\text { polski } \\
7 \%-\text { inny }\end{array}$ \\
\hline
\end{tabular}

Źródło: Die Ergebnisse der Volkszählung, s. 38-41, 58-73; S. Kasznica i in., Najważniejsze wyniki spisu ludności i spisu zwierząt domowych wedtug stanu zd. 31 grudnia $1910 \mathrm{r}$. (Wiadomości statystyczne o stosunkach krajowych wydawane przez Krajowe Biuro Statystyczne, t. 24, z. 1), Lwów 1911, s. 17-27; Schematismus der k.k. Landwehr und der k.k. Gendarmerie der Im Reichsrate Vertretenen Königreiche und Länder für 1913, Wien 1913, mapa; M. Ehnl, op. cit., s. 75-77, 79; Organische Bestimmungen für die k.k. Landsturmbezirkskommandos, „Normalverodnungsblatt für das k.u.k. Heer", 5. Stück vom 1 Februar 1913, A-101, s. 6, 9-11; Organische Bestimmungen für die k.k. Landwehr- (Landesschützen-) Ergänzungsbezirkskommandos, „Normalverodnungsblatt für das k.u.k. Heer", 5. Stück vom 1 Februar 1913, Beilage 1, s. 6-8.

Jak wynika z danych zaprezentowanych w tabeli, w większości przypadków struktura narodowościowa lub językowa oddziałów w dużej mierze odzwierciedlała strukturę narodowościową okręgu mobilizacyjnego. Bardzo ogólne informacje

${ }^{34} \mathrm{~W}$ Organische Bestimmungen für die k.k. Landsturmbezirkskommandos wymieniony jako siedziba powiatu. W istocie Radziechów leżał w powiecie kamioneckim. 
w kwestii składu narodowościowego k.k. 18 i 33 LstIR, które przekazał służący jako oficer w k.k. 18 LstIR Jan Vit, zdają się potwierdzać tę tezę. Wg Vita k.k. 33 LstIR składał się z Rusinów, zaś jego pułk w połowie z Rusinów, w połowie z Polaków ${ }^{35}$. W przypadku danych dla k.k. 10 LIR w 1914 r. można założyć, że mamy do czynienia z błędem (nie jedynym, na jaki możemy natknąć się w pracy Ehnla) i struktura narodowościowa k.k. 10 LstIR była bardziej zbliżona do struktury językowej okręgu mobilizacyjnego k.k. 10 LIR. W przypadku k.k. 10 LstIR, na podstawie struktury językowej jego okręgu mobilizacyjnego, można przyjąć, że żołnierze czescy mogli stanowić około połowy tej jednostki.

Osobnego omówienia wymaga kwestia granic okręgów mobilizacyjnych k.k. 17 i 34 LstIR. W tabeli wykorzystano dane zawarte w Organische Bestimmungen für die k.k. Landwehr- (Landesschützen-) Ergänzungsbezirkskommandos, Organische Bestimmungen für die k.k. Landsturmbezirkskommandos z 1913 r. oraz mape granic okręgów uzupełnień Landwehry z 1913 r. W przypadku 1912 r. były one inaczej zarysowanie - okręg mobilizacyjny k.k. 17 LIR obejmował też powiaty Nisko, Łańcut i Przeworsk ${ }^{36}$, które według danych z 1913 r. zaliczone były do okręgu mobilizacyjnego k.k. 34 LIR i 34 LstIR. Jednakże wedle wspomnień służącego w k.k. 17 LstIR Jana Lenarta, cały III batalion tego pułku uzupełniany był w powiecie łańcuckim (w jego kompanii służyło 13 mężczyzn z Handzlówki ${ }^{37}$ ), a zatem w granicach okręgu mobilizacyjnego z 1912 r. Jeśli dane te zastosować do składu językowego okręgów mobilizacyjnych k.k. 17 i 34 LstIR, to w granicach z 1912 r. w pierwszym ludność polska miała nadal zdecydowaną przewagę (ponad 98\%), jednakże w drugim traciła ona większość (42,9\% w stosunku do 56,1\% ludności ukraińskiej). Pewne zatem jest, że służący w Przemyślu cały k.k. 17 LstIR był zdecydowanie polskim pułkiem, nie wiadomo natomiast dokładnie, jaka była struktura narodowościowa dwóch batalionów k.k. 34 LstIR, poza tym, że służyli w nich żołnierze ukraińscy i polscy.

Pewne różnice w kwestii pochodzenia rezerwistów powołanych do służby w k.k. 18 LstIR znajdujemy też w pamiętnikach A. Krasickiego, który jako adiutant II baonu tego pułku uczestniczył w mobilizowaniu rezerwistów w sierpniu $1914 \mathrm{r}$. w Żurawicy. Wedle jego wspomnień znajdowali się wśród nich mieszkańcy powiatów przemyskiego, dobromilskiego, liskiego, brzozowskiego i przeworskiego ${ }^{38}$. Takie pochodzenie żołnierzy pułku sprawiałoby, że większy wśród nich byłby odsetek Polaków.

Odrębnego przedstawienia wymaga kwestia granic okręgu mobilizacyjnego c.k. Pułku Pospolitego Ruszenia Strzelców Krajowych Nr II (k.k. LstLdschR

${ }^{35} \mathrm{~J}$. Vit, Wspomnienia z mojego pobytu w Przemyślu podczas oblężenia rosyjskiego 1914-1915, Przemyśl 1995, s. 79-80.

${ }^{36}$ Schematismus der k.k. Landwehr und der k.k. Gendarmerie der Im Reichsrate Vertretenen Königreiche und Länder für 1912, Wien 1912, mapa.

${ }^{37}$ J. Lenar, Pamiętnik z walk o Twierdzę Przemyśl, Przemyśl 2005, s. 11.

${ }^{38}$ A. Krasicki, Dziennik z kampanji rosyjskiej, Lwów 1935, s. 12. 
Nr. II), uzupełnianego w Tyrolu i Voralbergu. Według danych ze spisu z $1910 \mathrm{r}$. z nieco ponad 132000 mieszkańców Voralbergu ponad 95\% było niemieckojęzycznych. Wśród mieszkańców Tyrolu ponad 57\% było niemieckojęzycznych, $42 \%$ włoskojęzycznych ${ }^{39}$, przy czym odsetek ludności włoskojęzycznej największy był w południowej części tego kraju koronnego. Należy zaznaczyć, że w przypadku Tyrolu i Voralbergu struktura terytorialna obszarów, na których mobilizowano jednostki pospolitego ruszenia, nie pokrywała się z obszarami mobilizacyjnym jednostek strzelców krajowych - o ile na terenie Tyrolu i Voralbergu tworzono trzy pułki strzelców krajowych, stanowiące odpowiednik jednostek Landwehry w pozostałych częściach Przedlitawii, to w przypadku pospolitego ruszenia tworzono tu jedynie dwa pułki. Cały ten obszar podzielony był na dwa okręgi pospolitego ruszenia: Nr I w Innsbrucku, z ekspozyturami w Imst i Schwaz, oraz Nr II w Bozen. W przypadku wojny w pierwszym okręgu, który obejmował Tyrol Północny i Voralberg, mobilizowano dwa pułki: c.k. Pułk Pospolitego Ruszenia Strzelców Krajowych Nr I (Innsbruck) i c.k. Pułk Pospolitego Ruszenia Strzelców Krajowych Nr II (Imst). W okręgu nr II nie tworzono pułków piechoty, tylko oddziały ochrony kolei oraz strzegące granicy (Grenzschutz). Okręg nr II obejmował powiaty i miasta: Borgo, Bozen, Brixen, Cavalese, Cles, Meran, Mezolombardo, Primiero, Riva, Rovereto, Schlanders, Tione, Trient ${ }^{40}$. Były to południowy Tyrol i według danych ze spisu z $1910 \mathrm{r}$. 34,7\% mieszkańców tego terenu posługiwało się językiem niemieckim, 59,6\% - językiem włoskim ${ }^{41}$. To wskazywałby, że większość żołnierzy pułku stanowić musieli Włosi. Jednakże wg Ottona Stolza I batalion k.k. LstLdschR Nr. II składał z żołnierzy z Oberinntal i Ausserfern, II z Voralbergu, III z Unterinntal ${ }^{42}$. Tereny te obejmowały Voralberg oraz zachodnią i północną część Tyrolu - okręgi Imst, Innsbruck, Landeck i Reutte, gdzie Niemcy stanowili prawie $97 \%{ }^{43}$. To sprawiało, że mobilizowany na tym obszarze pułk musiał mieć charakter zdecydowanie niemiecki, choć w III batalionie było sporo Włochów, którzy sprowadzili się do Innsbrucka, zaś w II sporo mieszkańców południowego Tyrolu (a zatem w części przynajmniej Włochów), którzy do Voralbergu przywędrowali za pracą ${ }^{44}$. Generalnie wg Stolza włoskojęzyczni żołnierze stanowili jedynie nieznaczny ułamek pułku ${ }^{45}$.

\footnotetext{
${ }^{39}$ Die Ergebnisse der Volkszählung vom 31. Dezember 1910 in der Im Reichsrate Vertretenen Königreichen und Länder, Heft 1, Die summarischen Ergebnisse der Volkszählung, Wien 1912, s. 59*.

${ }^{40}$ Organische Bestimmungen für die k.k. Landsturmbezirkskommandos, ,Normalverodnungsblatt für das k.u.k. Heer", 5. Stück vom 1 Februar 1913, A-101, s. 12; O. Stolz, Das Tiroler Landsturmregiment Nr. II im Kriege 1914-15 in Galizien, „Veröffentlichungen des Museums Ferdinandeum”, 18. Bd. (1938), s. 136-137.

${ }^{41}$ Die Ergebnisse der Volkszählung, s. 54-58.

${ }^{42}$ O. Stolz, op. cit., s. 149.

${ }^{43}$ Die Ergebnisse der Volkszählung, s. 56-59.

${ }^{44}$ O. Stolz, op. cit., s. 149.

${ }^{45}$ Ibidem, s. 192.
} 
Mamy tu więc do czynienia z niejasną sytuacją i w ustaleniu stanu faktycznego pomocne mogą być dane $\mathrm{z}$ „Listy Strat” $\mathrm{nr}$ 146, na której znajduje się szereg nazwisk poległych i rannych żołnierzy z k.k. LstLdschR Nr. II. Przy części zmarłych zaznaczono, że śmierć miała miejsce w Przemyślu i okolicy, daty zgonu kilku innych pochodzą z końca 1914 r. i też najprawdopodobniej odnoszą się do Przemyśla.

Na omawianej „Liście Strat” znalazło się 54 żołnierzy z k.k. LstLdschR Nr. II. 20 pochodziło z Tyrolu, z czego większość z powiatów z Północnego Tyrolu (należących do obszaru mobilizacyjnego k.k. LstIR. Nr. I): Imst - czterech, Innsbruck - jeden, Kitzbühel - dwóch, Kufstein - jeden, Landeck - czterech, Reute - pięciu (przy jednym nazwisku nie podano powiatu). Z powiatów południowego Tyrolu pochodziło tylko dwóch: jeden z Borgo (tylko ten - sądząc po imieniu i nazwisku Giuseppe Brandoisi - był Włochem), jeden z Mezolombardo. 19 żołnierzy pochodziło z Vorlabergu ${ }^{46}$. Dane te dają podstawę do twierdzenia, że k.k. LstLdschR Nr. II. mobilizowany był nie w południowym, ale w północnym Tyrolu.

Do jednostek przedlitawskich należały też cztery bataliony pospolitego ruszenia należące do grupy gen. Wilhelma Nickla ${ }^{47}$. Grupa ta została utworzona z jednostek ochrony kolei, żandarmerii i saperów. We wrześniu 1914 r. wzmocniono ją batalionem marszowym c.k. 19 Pułku Piechoty Landwehry"8, a więc jednostką uzupełnianą w rejonie Lwowa. Można założyć, że w sumie w znacznej mierze bataliony tej grupy złożone były z żołnierzy pochodzących z Galicji. Dowodzący jedną z kompanii tej grupy por. Tyro wskazał, że przeważnie składała się ona z „lwowskich batiarów"49.

Podkreślić należy, że kadrę oficerską jednostek galicyjskich tworzyli przede wszystkim Niemcy i Czesi, w dalszej kolejności Polacy. Korpus oficerski jednostek austriackiego pospolitego ruszenia kompletowany był w dużej mierze spośród oficerów rezerwy i dla tych trzech narodowości odpowiednie wartości wśród oficerów rezerwy przedstawiały się następująco: Niemcy $-56,8 \%$, Czesi - 10,6\%, Polacy $3,3 \%{ }^{50}$, choć w jednostkach galicyjskich odsetek Polaków móg1 być większy, ale najprawdopodobniej nie dominujący. Przykładowo, w swych wspomnieniach Jan Vit na 71 oficerów służących w batalionach k.k. 18 LstIR podał pochodzenie 58: 35 z Czech i Moraw, 12 z Wiednia, dwóch ze Śląska Cieszyńskiego, sześciu z Galicji ${ }^{51}$.

\footnotetext{
${ }^{46}$ „Verlustliste”, nr 146 z 22 marca 1915 r.

${ }^{47}$ B. Geöcze, op. cit., załącznik nr 1; O. Stolz, op. cit., s. 180.

${ }^{48}$ H. Heiden, op. cit., s. 48.

${ }^{49}$ Por. Stanisław Tyro-naoczny świadek walko Twierdzę Przemyśl, oprac. A. Durkacz-Foremska i M. Wołk, Przemyśl 2020, s. 81.

${ }^{50}$ Österreich-Ungarns letzter Krieg, 2. Bd., Das Kriegsjahr 1915, 2. Teil, Beilagen, Wien 1931 (dalej: $\ddot{O} U L K, 2$ ), Tab. 5.

${ }^{51}$ J. Vit, op. cit., s. 91-92.
} 
Przedstawiając jednostki węgierskiej Obrony Krajowej (Honwedu) oraz węgierskiego pospolitego ruszenia walczące w Twierdzy Przemyśl, trzeba zwrócić uwagę na przedstawioną wyżej strukturę narodowościową Królestwa Węgierskiego, ale też na rozmieszczenie poszczególnych narodowości w zamkniętym łukiem Karpat basenie Dunaju, który zakreślał ramy geograficzne ówczesnych Węgier. Sami Węgrzy skupieni byli w zachodniej i centralnej części tego obszaru. Liczna ludność węgierska zamieszkiwała też tereny peryferyjne, przede wszystkim wschodni Siedmiogród, jako całość zdominowany jednak przez ludność rumuńską, stanowiącą największą po Madziarach grupę narodowościową Węgier. Pozostałe narodowości także rozmieszczone były peryferyjnie: na północy zwartą masą mieszkali Słowacy, na północnym-wschodzie Rusini, na południu Serbowie, na południowym zachodzie Chorwaci. $Z$ różnym natężeniem na obszarze całego państwa (szczególnie w miastach) rozrzucona była ludność niemiecka.

Takie rozmieszczenie narodowości znajdowało odbicie w składzie narodowościowym jednostek węgierskich, które walczyły w Twierdzy Przemyśl, a które w dużej mierze pochodziły z obrzeży Królestwa Węgierskiego.

Najważniejszą jednostką węgierską walczącą w Twierdzy Przemyśl była k.węg. 23 Dywizja Piechoty Honwedu (k.u. 23 LITD ${ }^{52}$ ). Jej struktura (jeśli chodzi o jednostki piechoty) w chwili wybuchu wojny przedstawiała się następująco:

\section{Tabela 3. Struktura k.węg. 23 Dywizji Piechoty Honwedu.}

\begin{tabular}{|c|c|c|c|}
\hline \multicolumn{4}{|c|}{ k.węg. 23 Dywizja Piechoty Honwedu (k.u. 23 LITD) } \\
\hline \multicolumn{2}{|c|}{$\begin{array}{c}\text { k.węg. } 45 \text { Brygada Piechoty Honwedu } \\
\text { (k.u. } 45 \text { LIBrig) }\end{array}$} & \multicolumn{2}{|c|}{$\begin{array}{c}\text { k.węg. } 46 \text { Brygada Piechoty Honwedu } \\
\text { (k.u. } 46 \text { LIBrig) }\end{array}$} \\
\hline $\begin{array}{c}\text { k.węg. } \\
2 \text { Pułk Piechoty } \\
\text { Honwedu } \\
\text { (k.u. 2 LIR) }\end{array}$ & $\begin{array}{c}\text { k.węg. } \\
5 \text { Pułk Piechoty } \\
\text { Honwedu } \\
\text { (k.u. } 5 \text { LIR) }\end{array}$ & $\begin{array}{c}\text { k.węg. } \\
7 \text { Pułk Piechoty } \\
\text { Honwedu } \\
\text { (k.u. } 7 \text { LIR) }\end{array}$ & $\begin{array}{c}\text { k.węg. } \\
8 \text { Pułk Piechoty } \\
\text { Honwedu } \\
\text { (k.u. } 8 \text { LIR) }\end{array}$ \\
\hline \multicolumn{2}{|c|}{$\begin{array}{c}\text { k.węg. } 3 \text { Pułk Marszowy Honwedu } \\
\text { (k.u. } 3 \text { MarschIR) }\end{array}$} & \multicolumn{2}{|c|}{$\begin{array}{l}\text { k.węg. } 4 \text { Pułk Marszowy Honwedu } \\
\text { (k.u. } 4 \text { MarschIR) }\end{array}$} \\
\hline
\end{tabular}

Źródło: A m. kir. Honvédség hadrendje békében: az 1914. évi tavaszán történt helyőrségváltoztatások után (lezárva 1914 április hó 1-én), Budapest 1914, s. 4; B. Geöcze, op. cit., załącznik nr 1.

Jak już wspomniano, pułki marszowe były tworzone w okręgach mobilizacyjnych określonych pułków z rezerwistów, których liczba w czasie mobilizacji przekraczała możliwości przyjęcia ich przez istniejące już pułki. Ich skład narodowościowy siłą rzeczy był również wypadkową struktury narodowościowej terenów, na których je utworzono.

${ }^{52}$ Landwehr Infanterie Truppen-Division (Truppen-Division - dywizja, w odróżnieniu od Division - dywizjon), zob. W. Włoskowicz, Nazwy austro-węgierskich jednostek wojskowych. Studium polityki nazewniczej z zakresu chrematonimii wojskowej, ,Onomastica”, R. 64 (2020), s. 127 i przypis 11, s. 131. 
Tabela 4. Struktura językowa okręgów mobilizacyjnych pułków k.u. 23 LITD.

\begin{tabular}{|c|c|c|}
\hline $\begin{array}{c}\text { Okręg mobilizacyjny pułku piechoty } \\
\text { Honwedu (k.u. LIR) }\end{array}$ & $\begin{array}{c}\text { Struktura językowa } \\
\text { okręgu } \\
\text { mobilizacyjnego } \\
\text { wg danych ze spisu } \\
\text { z } 1910 \mathrm{r} \text {. }\end{array}$ & $\begin{array}{c}\text { Struktura językowa } \\
\text { oddziałów k.u. LIR } \\
\text { w } 1914 \text { r. }\end{array}$ \\
\hline $\begin{array}{l}\text { K.u. } 2 \text { LIR (Gyula) } \\
\text { Komitat Arad (bez powiatu Nagy- } \\
\text { halmágy), powiaty Lippa, Ujarad } \\
\text { i Vinga komitatu Temes, powiaty } \\
\text { Nagylak, Battonya komitatu Csa- } \\
\text { nád, powiat i miasto Gyula komitatu } \\
\text { Békés }\end{array}$ & $\begin{array}{l}\text { 46,8\% - rumuński } \\
\text { 33,5\% - węgierski } \\
\text { 14\% - niemiecki } \\
\text { 5,7\% - inny }\end{array}$ & $\begin{array}{l}54 \% \text { - rumuński } \\
28 \% \text { - węgierski } \\
18 \% \text { - inny }\end{array}$ \\
\hline $\begin{array}{l}\text { K.u. } 5 \text { LIR (Szeged) } \\
\text { Komitat Csongrád, miasto Makó } \\
\text { z powiatem komitatu Csanád, powia- } \\
\text { ty Törökkanizsa, Nagyszentmiklos, } \\
\text { Perjamos, Zsombolya, Csene komi- } \\
\text { tatu Torontál. }\end{array}$ & $\begin{array}{l}70,9 \% \text { - węgierski } \\
13,3 \% \text { - niemiecki } \\
6,6 \% \text { - rumuński } \\
5,9 \% \text { - serbski } \\
\text { 3,3\% - inny }\end{array}$ & $\begin{array}{l}79 \% \text { - węgierski } \\
21 \% \text { - inny }\end{array}$ \\
\hline $\begin{array}{l}\text { K.u. } 3 \text { MarschIR } \\
\text { Okręg mobilizacyjny obejmował } \\
\text { okręgi mobilizacyjne k.u. } 2 \text { i k.u. } 5 \\
\text { LIR. }\end{array}$ & $\begin{array}{l}52,4 \% \text { - węgierski } \\
26,4 \% \text { - rumuński } \\
13,4 \% \text { - niemiecki } \\
3,8 \% \text { - serbski } \\
4 \% \text { - inny }\end{array}$ & b. d. \\
\hline $\begin{array}{l}\text { K.u. } 7 \text { LIR (Versecz) } \\
\text { Powiaty Nagykikinda, Törökbecse, } \\
\text { Párdány, Nagybecskerek, Módos, } \\
\text { Bánlak, Antalfalva, Alibunár, Panc- } \\
\text { sova komitatu Torontál, powiaty } \\
\text { Csák, Detta, Versecz, Fehértemplom, } \\
\text { Kevevára komitatu Temes }\end{array}$ & $\begin{array}{l}36,2 \% \text { - serbski } \\
23,4 \% \text { - niemiecki } \\
19,3 \% \text { - rumuński } \\
16 \% \text { - węgierski } \\
\text { 5,1\% - inny }\end{array}$ & $\begin{array}{l}44 \% \text { - serbochorwacki } \\
56 \% \text { - inny }\end{array}$ \\
\hline $\begin{array}{l}\text { K.u. } 8 \text { LIR (Lugos) } \\
\text { Komitat Krassó-Szörény oraz miasto } \\
\text { Temesvár z przynależnym powiatem } \\
\text { powiaty Temesrékas, Buziasfördö, } \\
\text { komitatu Temes }\end{array}$ & $\begin{array}{l}\text { 61,2\% - rumuński } \\
18,4 \% \text { - niemiecki } \\
12,2 \% \text { - węgierski } \\
3,5 \% \text { - serbski } \\
\text { 4,7\% - inny }\end{array}$ & $\begin{array}{l}78 \% \text { - serbochorwacki } \\
22 \% \text { - inny }\end{array}$ \\
\hline
\end{tabular}




\begin{tabular}{|l|l|l|}
\hline K.u. 4 MarschIR & $41 \%$ - rumuński & b.d. \\
Okręg mobilizacyjny obejmujący & $20,8 \%$ - niemiecki & \\
okręgi mobilizacyjne k.u. 7 i 8 LIR & $19,2 \%$ - serbski & \\
& $14 \%$ - węgierski & \\
& $5 \%$ - inny & \\
\hline
\end{tabular}

Źródło: A magyar királyi Honvédség elhelyezési térképe, [1910?]; A Magyar Szent Korona, s. 182-183, 278-279, 340-343, 354-355, 364-365, 372-373; M. Ehnl, op. cit., s. 84-85.

Struktura językowa całego obszaru mobilizacyjnego k.u. 23 LITD przedstawiała się następująco: 34,2\% ludności posługiwało się językiem rumuńskim, 32,4\% węgierskim, 17,4\% - niemieckim, 11,8\% - serbskim, 4,2\% - innym.

Jak wynika z powyższych danych, najliczniejszą grupą narodowościową na tym terenie byli Rumuni, stanowiący nieco ponad 1/3 ogółu ludności terytorium, na którym mobilizowana była k.u. 23 LITD. Jednakże mieli oni jedynie nieznaczną przewagę nad Węgrami, stanowiącymi nieco tylko mniej niż 1/3 ludności tego obszaru. Znaczący był tu też odsetek ludności niemieckojęzycznej i serbskiej ${ }^{53}$. Musiało to znaleźć swoje odzwierciedlenie w składzie narodowościowym dywizji, w której tylko w k.u. 5 LIR Węgrzy stanowili większość. Dane przedstawione przez Ehnla w ogólnym zarysie potwierdzają tę tezę. W przypadku k.u. 8 LIR należy zwrócić uwagę na fakt, że był on mobilizowany na terenach, na których przeważała ludność rumuńska. W opracowaniu Ehnla rubryka prezentująca dane dla języków serbskiego, chorwackiego i serbochorwackiego sąsiaduje z rubryką zawierającą informacje odnoszące się do języka rumuńskiego. Biorąc pod uwagę skład narodowościowy obszarów uzupełnień tego pułku można założyć, że zaszła pomyłka w druku (dane wpisano w niewłaściwej rubryce) i owe 78\% niewątpliwie odnosi się do żołnierzy posługujących się językiem rumuńskim.

Niestety, nie mamy dokładnych informacji o składzie narodowościowym pułków tworzących k.u. 23 LITD w czasie walk o Przemyśl.

Trudno wydawać kategoryczne sądy w tej materii, bowiem fragmentaryczne dane o składzie narodowościowym pułków dywizji, jakie znajdujemy w niektórych opracowaniach źródłowych i prasie, wskazują jednak na wyższy niż przedstawiony wyżej odsetek żołnierzy narodowości węgierskiej w poszczególnych jednostkach. W relacji dotyczącej walk II batalionu k.u. 7 LIR w okresie walk o wzgórze

${ }^{53}$ Do nieco innych wniosków na podstawie danych ze spisu z 1910 r. doszedł A. Watson, który jedynie 7 i 8 Pułk uznał za mobilizowane na terenach zamieszkanych przez przeważającą ludność niewęgierską, pozostałe zaś pułki dywizji za uzupełniane na terenach z dominującą liczbą ludności węgierskiej. Nie podał on jednak wyliczeń, na podstawie których doszedł do takich konkluzji, zob. A. Watson, op. cit., s. 71. 
Magiera $^{54}$ (druga połowa października, początek listopada 1914 r.) podano, że batalion ów składał się w 52\% z Węgrów, 30\% z Rumunów i 18\% z Niemców ${ }^{55}$. Odsetek Węgrów w tym oddziale był znacznie wyższy niż mogłoby to wynikać ze składu narodowościowego terenów, na których mobilizowany był k.u. 7 LIR oraz różnił się od danych zawartych w pracy Ehnla. Zwraca uwagę brak w tym batalionie żołnierzy narodowości serbskiej. Związane jest to z tym, że II batalion k.u. 7 LIR miał swą siedzibę w Oraviczabánya i jego okręg mobilizacyjny ulokowany był w południowo-zachodniej części komitatu Krassó-Szörény. W ogólnym zarysie były to powiaty Boksánbánya, Jám i Oravicsabánya, których struktura narodowościowa w 1910 r. była następująca: Rumuni stanowili tu 75,6\% ludności, Niemcy $14, \%$, Węgrzy $4,5 \%$, Serbowie zaledwie $1,5 \%{ }^{56}$.

W przypadku k.u. 5 LIR ogólne informacje przynosi relacja z zaprzysiężenia pułku 2 sierpnia 1914 r. Wedle niej przeważającą większość jednostki stanowili Węgrzy, ok. 100 żołnierzy mówiło w języku niemieckim, mniej więcej tyle samo w języku rumuńskim, ok. 60-70 w języku serbskim ${ }^{57}$. Przy założeniu, że pułk liczył 3500 żołnierzy (taką liczbę podawał jego dowódca Dezső Nónay odnośnie liczebności jednostki na początku wojny ${ }^{58}$ ), oznaczałoby to, że Węgrzy stanowili ponad $92 \%$ składu jednostki, Niemcy i Rumuni po ok. 3\%, a Serbowie ok. $2 \%$.

Pośrednio o składzie narodowościowym pułków k.u. 23 LITD można sądzić w oparciu o informacje o ich składzie wyznaniowym.

Struktura wyznaniowa Królestwa Węgierskiego była równie złożona, jak struktura narodowościowa państwa. Generalną zasadą było powiązanie narodowości z określonym wyznaniem - Węgrzy i Niemcy w większości byli rzymskimi katolikami bądź należeli do jednego z wyznań protestanckich, Serbowie i Rumuni w przeważającej większości należeli do kościoła prawosławnego ${ }^{59}$. Znikomy był odsetek Węgrów wyznających prawosławie - w 1900 r. było to zaledwie $0,41 \%$ ogółu populacji węgierskiej ${ }^{60}$.

O ogólnym składzie wyznaniowym poszczególnych pułków k.u. 23 LITD pozwalają wnioskować organizowane dla jej żołnierzy uroczystości religijne.

\footnotetext{
${ }^{54} 15 \mathrm{~km}$ na południowy wschód od Przemyśla.

${ }_{55}^{5}$ J. Gabányi, Magiera (Részlet a 7. honvéd gyalogezred naplójából), „Hadtörténelmi Közlemények", t. 28 (1927), s. 568.

${ }^{56}$ A Magyar Szent Korona Országainak 1910. évi népszámlása, 1. rész, A népesség föbb adatai. Községek és népesebb puszták, telepek szerint, Budapest 1912, s. 354-355.

57 „Délmagyarország”, R. 3, nr 187 (wydanie specjalne) z 3 sierpnia 1914 r., s. 2.

${ }^{58}$ D. Nónay, op. cit., s. 10. Pułk jednakże mógł liczyć nieco więcej żołnierzy. Standardowo pułki o trzech batalionach na stopie wojennej liczyły po 3648 oficerów i żołnierzy, zob. T. Nowakowski, op. cit., s. 28. Nie są znane dokładne dane dla pułków k.u. LITD 23, ale przykładowo można przytoczyć dane dla k. węg. 1 Pułku Piechoty Honwedu, który po mobilizacji liczył w sumie 83 oficerów i 3610 żołnierzy, przy czym stan bojowy pułku wynosił 68 oficerów i 3400 żołnierzy, zob. F. Kepes, 1. honvéd gyalogezred története és háborús emlékalbuma, Budapest 1939, s. 40.

${ }^{59}$ Magyarország története a 19. században, szerk. A. Gergely, Budapest 2005, s. 418.

${ }^{60}$ L. Katus, Die Magyaren, w: Die Habsburgermonarchie 1848-1918, 3. Bd., Die Völker des Reiches, 1. Tb., hrsg. von A. Wandruszka, P. Urbanitsch, Wien 1980, s. 441.
} 
Na początku 1915 r. z okazji prawosławnych świąt Bożego Narodzenia przypadających na początek stycznia, 7 dnia tego miesiąca odprawiono dwie msze prawosławne, pierwszą dla żołnierzy k.u. 8 LIR, drugą dla żołnierzy z k.u. 7 LIR $^{61}$. Pod koniec stycznia wśród żołnierzy k.u. 23 LITD zorganizowano rekolekcje według planu: rzymsko-katolicki kapelan miał przeprowadzić je w k.u. 7 LIR w dniach 14-16 stycznia, 18-19 stycznia w dowództwie k.u. 3 MarschIR i II oraz III batalionie, 20 stycznia w I batalionie tegoż pułku. Kapelan prawosławny 14 stycznia w sztabie i III batalionie k.u. 2 LIR, 15 stycznia w II batalionie, 16 stycznia w I batalionie tegoż pułku, w k.u. 4 MarschIR w I batalionie 18 stycznia, II i III batalionie 19-20 stycznia ${ }^{62}$.

Wprawdzie brak danych ilościowych, co do przedstawicieli poszczególnych wyznań w konkretnych pułkach, to jednak wyraźnie widać, że k.u. 23 LITD miała złożony skład wyznaniowy (a co za tym idzie także narodowościowy) i że żołnierze wyznający prawosławie musieli być licznie reprezentowani w k.u. 2, 7 i 8 LIR. Zważywszy na powiązanie poszczególnych pułków z określonym terytorium, w przypadku 2 i 8 pułku mamy do czynienia przede wszystkim z Rumunami, w przypadku 7 pułku z Rumunami i Serbami.

Podsumowując można stwierdzić, że w przypadku k.u. 23 LITD wcale nie jest pewne, czy w większości tworzyli ją żołnierze narodowości węgierskiej - na pewno przeważali oni w 5 pułku. Wydaje się, że w 2 i 8 pułku większość mogli stanowić żołnierze narodowości rumuńskiej, w 7 - serbskiej i rumuńskiej. Należy pamiętać, że zdecydowaną większość kadry oficerskiej dywizji stanowili jednak Węgrzy, choć także tu zdarzały się wyjątki i wśród służących tu oficerów trafiali się przedstawiciele innych narodowości, którzy jednakże nie mogli stanowić dużej grupy - o ile Węgrzy stanowili ponad $10 \%$ oficerów służby czynnej i $24,5 \%$ oficerów rezerwy, to Rumuni odpowiednio 1 i $0,7 \%$. W przypadku Serbów mamy dane tylko łącznie z Chorwatami - odpowiednio 2,7 i $1,9 \%{ }^{63}$.

Poza pułkami k.u. 23 LITD w Twierdzy Przemyśl znajdowały się jeszcze dwa pułki marszowe Honwedu - k.węg. 6 Pułk Marszowy Honwedu (k.u. 6 MarschIR) oraz k.węg. 16 Pułk Marszowy Honwedu (k.u. 16 MarschIR).

K.u. 6 MarschIR utworzony był na bazie k.węg. 10 Pułku Piechoty Honwedu (k.u. 10 LIR) i k.węg. 16 Pułku Piechoty Honwedu (k.u. 16 LIR), a więc na terenach dzisiejszych północnych Węgier i pogranicza słowacko-węgierskiego oraz centralnej i zachodniej Słowacji. Skład językowy terenów, na których mobilizowany była ta jednostka, w 1910 r. przedstawiał się następująco:

${ }^{61}$ Muzeum Narodowe Ziemi Przemyskiej, Archiwum ppłk. Eleka Molnára [dalej: MNZP. ApEM], Teka 7, sygn. MP-Hist. 394, k. 8.

${ }^{62}$ „Tábori Ujság”, nr 85 z 16 stycznia 1915 r., s. 2.

${ }^{63} \ddot{O} U L K, 2$, Tab. 5. 
Tabela 5. Struktura językowa okręgów mobilizacyjnych k.u. 10 i 16 LIR.

\begin{tabular}{|c|c|c|}
\hline $\begin{array}{c}\text { Okręg mobilizacyjny pułku piechoty } \\
\text { Honwedu (k.u. LIR) }\end{array}$ & $\begin{array}{c}\text { Struktura językowa } \\
\text { okręgu } \\
\text { mobilizacyjnego } \\
\text { wg danych ze spisu } \\
\text { z } 1910 \mathrm{r} \text {. }\end{array}$ & $\begin{array}{l}\text { Struktura językowa } \\
\text { oddziałów k.u. LIR } \\
\text { w } 1914 \text { r. }\end{array}$ \\
\hline $\begin{array}{l}\text { K.u. } 10 \text { LIR (Miskolc) } \\
\text { Komitaty Borsod, Heves oraz powia- } \\
\text { ty Szerencs, Tokaj, Sárospatak, Bo- } \\
\text { drogközi i Sátoraljaujhely komitatu } \\
\text { Zemplén }\end{array}$ & $\begin{array}{l}97,7 \% \text { - węgierski } \\
1,4 \% \text { - słowacki } \\
0,9 \% \text { - inny }\end{array}$ & $\begin{array}{l}98 \%-\text { węgierski } \\
2 \%-\text { inny }\end{array}$ \\
\hline $\begin{array}{l}\text { K.u. } 16 \text { LIR (Beszterczebánya) } \\
\text { Komitaty Gömör és Kis-Hont, No- } \\
\text { grád, Zólyom }\end{array}$ & $\begin{array}{l}55,6 \% \text { - węgierski } \\
41,8 \% \text { - słowacki } \\
1,4 \% \text { - niemiecki } \\
1,2 \% \text { - inny }\end{array}$ & $\begin{array}{l}56 \% \text { - węgierski } \\
41 \% \text { - słowacki } \\
3 \% \text { - inny }\end{array}$ \\
\hline $\begin{array}{l}\text { Struktura językowa obydwu okrę- } \\
\text { gów mobilizacyjnych }\end{array}$ & $\begin{array}{l}79,2 \% \text { - węgierski } \\
19,1 \% \text { - słowacki } \\
1,7 \% \text { - inny }\end{array}$ & b. d. \\
\hline
\end{tabular}

Źródło: A magyar királyi Honvédség elhelyezési térképe, [1910?]; A Magyar Szent Korona, s. 128-129, 176-177, 188-189, 222-223, 232-233, 276-277; M. Ehnl, op. cit., s. 86-87.

Biorąc pod uwagę łączną strukturę językową obszarów mobilizacyjnych k.u. 10 i 16 LIR można założyć, że w k.u. 6 MarschIR dominował element węgierski. Pułk ten rozwiązano we wrześniu i październiku 1914 r. i służących w nim oficerów i żołnierzy przydzielono do pułków k.u. 23 LITD $^{64}$, przez co zapewne wzmocniony w nich został odsetek żołnierzy narodowości węgierskiej.

Odmienna sytuacja miała miejsce w przypadku k.u 16 MarschIR. Pułk ten był utworzony na bazie k.węg. 12 Pułku Piechoty Honwedu (k.u. 12 LIR) i k.węg. 32 Pułku Piechoty Honwedu (k.u. 32 LIR). Skład językowy terenów, na których mobilizowany była ta jednostka, w 1910 r. przedstawiał się następująco:

\footnotetext{
${ }^{64}$ B. Geöcze, op. cit., załącznik nr 1 .
} 
Tabela 6. Struktura językowa okręgów mobilizacyjnych k.u. 12 i 32 LIR.

\begin{tabular}{|c|c|c|}
\hline $\begin{array}{c}\text { Okręg mobilizacyjny pułku piechoty } \\
\text { Honwedu (k.u. LIR) }\end{array}$ & $\begin{array}{c}\text { Struktura językowa } \\
\text { okręgu } \\
\text { mobilizacyjnego } \\
\text { wg danych ze spisu } \\
\text { z } 1910 \mathrm{r} \text {. }\end{array}$ & $\begin{array}{l}\text { Struktura językowa } \\
\text { oddziałów k.u. LIR }\end{array}$ \\
\hline \multirow{5}{*}{$\begin{array}{l}\text { K.u. } 12 \text { LIR (Szatmár) } \\
\text { Komitat Szatmár (bez powiatów Fe- } \\
\text { hérgyarmat i Matészálka), komitaty } \\
\text { Máramaros, Ugocsa }\end{array}$} & $37,4 \%$ - węgierski & $58 \%$ - węgierski \\
\hline & $27,8 \%$ - rumuński & $39 \%$ - rumuński \\
\hline & $25,2 \%$ - ukraiński & $3 \%-$ inny \\
\hline & $9,2 \%$ - niemiecki & \\
\hline & $0,4 \%$ - inny & \\
\hline K.u. 32 LIR (Dés) & $67,7 \%$ - rumuński & $73 \%$ - rumuński \\
\hline \multirow{3}{*}{$\begin{array}{l}\text { Komitaty Besztercze-Nászod, Szol- } \\
\text { nok-Doboka, Szilágy }\end{array}$} & $24,6 \%$ - węgierski & $27 \%$ - inny \\
\hline & $5,5 \%$ - niemiecki & \\
\hline & $2,2 \%-$ inny & \\
\hline \multirow{5}{*}{$\begin{array}{l}\text { Struktura językowa obydwu okrę- } \\
\text { gów mobilizacyjnych }\end{array}$} & $45,4 \%$ - rumuński & \\
\hline & $31,7 \%$ - węgierski & \\
\hline & 14\% - ukraiński & \\
\hline & $7,5 \%$ - niemiecki & \\
\hline & $1,4 \%$ - inny & \\
\hline
\end{tabular}

Źródło: A magyar királyi Honvédség elhelyezési térképe, [1910?]; A Magyar Szent Korona, s. 304-305, 320-321, 328-329, 332-333, 382-383, 448-449; M. Ehnl, op. cit., s. 86, 89.

Jak wynika $\mathrm{z}$ danych zawartych $\mathrm{w}$ tabeli, żołnierze rumuńscy musieli stanowić znaczącą część k.u. 16 MarschIR. Pułk ten (na początku wojny liczący 3260 żołnierzy i oficerów ${ }^{65}$ ), który 4 września 1914 r. opuścił Szatmár i 7 września przy pełnym stanie osobowym dotarł do Przemyśla ${ }^{66}$, rozwiązano w styczniu $1915 \mathrm{r}$. i jego żołnierzami uzupełniono straty w pułkach k.u. 23 LITD. O sporym udziale Rumunów w k.u. 16 MarschIR świadczył wpis jednego z oficerów k.u. 5 LIR, który po przeprowadzonej reorganizacji napisał, że z III batalionu k.u. 16 MarschIR do I baonu 5 pułku przybyło 87 Rumunów, których, ze względu na fakt, że uważano ich za niegodnych zaufania, rozdzielono pomiędzy poszczególne kompanie batalionu. Także II batalion 5 pułku otrzymał odpowiednią ilość Rumunów z 16 pułku $^{67}$. Zważywszy na fakt, że po uzupełnieniach bataliony 5 pułku liczyły mniej

\footnotetext{
65 „Szamos”, R. 47, nr 82 z 28 marca 1915 r., s. 2.

${ }^{66}$ „Egri Ujság”, R. 25, nr 160 z 16 lipca 1918, s. 1.

${ }^{67}$ D. Nónay, op. cit., s. 165.
} 
niż 1000 żołnierzy (II baon 960 98 ), mogło to oznaczać wzrost liczby niewęgierskich żołnierzy w batalionach tego pułku o prawie $10 \%$.

$\mathrm{W}$ odniesieniu do jednostek węgierskiego pospolitego ruszenia walczących w Twierdzy Przemyśl, to także tu istotny był czynnik kompozycji etnicznej terenów, z których te jednostki pochodziły. $Z$ węgierskich jednostek pospolitego ruszenia w Przemyślu walczyła k.węg. 97 Brygada Pospolitego Ruszenia (k.u. 97 LstIBrig), złożona z czerech pułków: k.węg. 9 Pułku Pospolitego Ruszenia (k.u. 9 LstIR), k.węg. 10 Pułku Pospolitego Ruszenia (k.u. 10 LstIR), k.węg. 11 Pułku Pospolitego Ruszenia (k.u. 11 LstIR), k.węg. 16 Pułku Pospolitego Ruszenia (k.u. 16 LstIR). Były to pułki mobilizowane na terenie dzisiejszej centralnej i wschodniej Słowacji, północnych Węgier i Ukrainy Zakarpackiej. Podobnie jak w przypadku przedlitawskich pułków pospolitego ruszenia, nie mamy danych odnoszących się do składu narodowościowego tych jednostek, ale można je ustalić w przybliżeniu na podstawie struktury językowej obszarów, na których były one mobilizowane wraz z zestawieniem danych dla odpowiednich pułków piechoty Honwedu (k.u. LIR) w czerwcu 1914 r.

Tabela 7. Struktura językowa i narodowościowa okręgów mobilizacyjnych k.u. 9, 10,11 i 16 LstIR.

\begin{tabular}{|c|c|c|}
\hline Okręg mobilizacyjny & $\begin{array}{c}\text { Struktura językowa } \\
\text { okręgu mobilizacyjne- } \\
\text { go wg danych ze spisu } \\
\text { z } 1910 \mathrm{r} \text {. }\end{array}$ & $\begin{array}{l}\text { Struktura językowa } \\
\text { oddziałów k.u. LIR } \\
\text { w } 1914 \text { r. }\end{array}$ \\
\hline \multirow{5}{*}{$\begin{array}{l}\text { K.u. } 9 \text { LIR (Kassa) } \\
\text { Komitaty Abaúj-Torna, Liptó, Sáros, } \\
\text { Szepes, powiaty Gálszécs, Nagymi- } \\
\text { hály, Varannó, Homonna, Szinna, } \\
\text { Sztropkó, Mezőlaborcz komitatu } \\
\text { Zemplén }\end{array}$} & $45,8 \%$ - słowacki & \multirow{5}{*}{$\begin{array}{l}91 \% \text { - węgierski } \\
9 \% \text { - inny }\end{array}$} \\
\hline & $27,3 \%$ - węgierski & \\
\hline & $10,9 \%-$ niemiecki & \\
\hline & $10,6 \% \%$ - ukraiński & \\
\hline & $5,6 \%$ - inny & \\
\hline K.u. 10 LIR (Miszkolc) & $97,7 \%$ - węgierski & $98 \%$ - węgierski \\
\hline \multirow{2}{*}{$\begin{array}{l}\text { Komitaty Borsod, Heves oraz powia- } \\
\text { ty Szerencs, Tokaj, Sárospatak, Bo- } \\
\text { drogköz oraz miasto i powiat Sáto- } \\
\text { raljaujhely komitatu Zemplén }\end{array}$} & $1,4 \%$ - słowacki & \multirow[t]{2}{*}{$2 \%-$ inny } \\
\hline & $0,9 \%$ - inny & \\
\hline \multirow{5}{*}{$\begin{array}{l}\text { K.u. } 11 \text { LIR (Munkács) } \\
\text { Komitaty Bereg, Szabolcs, Ung oraz } \\
\text { powiaty Fehérgyarmat i Matészálka } \\
\text { komitatu Szatmár }\end{array}$} & 70,4\% - węgierski & $42 \%$ - węgierski \\
\hline & 20,4\% - ukraiński & $40 \%$ - słowacki \\
\hline & $4,9 \%$ - słowacki & $10 \%$ - ukraiński \\
\hline & $3,8 \%$ - niemiecki & $8 \%$ - inny \\
\hline & $0,5 \%$ - inny & \\
\hline
\end{tabular}

${ }^{68}$ Ibidem, s. 163. 


\begin{tabular}{|l|l|l|}
\hline K.u. 16 LIR (Beszterczebánya) & $55,6 \%$ - węgierski & $56 \%$ - węgierski \\
Komitaty Gömör és Kis-Hont, No- & $41,8 \%$ - słowacki & $41 \%$ - słowacki \\
grád, Zólyom & $1,4 \%$ - niemiecki & $3 \%$ - inny \\
& $1,2 \%$ - inny & \\
\hline $\begin{array}{l}\text { Struktura językowa całego obszaru } \\
\text { mobilizacyjnego k.u. 97 LstIBrig }\end{array}$ & $62,4 \%$ - węgierski & b.d. \\
& $\begin{array}{l}22,7 \% \text { - słowacki } \\
\end{array}$ & \\
& $4,5 \%$ - ukraiński & \\
& $1,9 \%$ - niemiecki & \\
\hline
\end{tabular}

Źródło: A Magyar Szent Korona, s. 120-121, 128-129, 176-17, 188-189, 208-209, 216-217, 222-223, 232-233, 246-247, 254-255, 262-263, 276-277, 310-311, 320-321; M. Ehnl, op. cit., s. 85-86; Übersicht der Aufteilung der Länder der heiligen Krone Ungarns in Landsturmkommandobereiche, „Normalverordnungblatt für das k.u.k. Heer”, 32. Stück, vom 4 Juli 1914, Beilage 1 zu $\S \S 1$ und 2, s. 4-5, 8.

Z danych w tabeli wynika, że k.u. 97 LstIBrig mobilizowana była na terenach, na których większość stanowiła ludność węgierska. Porównując dane ze spisu ludności z 1910 r. z danymi o składzie językowym pułków Honwedu latem 1914 r. widać, że w przypadku k.u. 10 i 16 LIR skład językowy tych jednostek niemalże idealnie odzwierciedlał strukturę narodowościową ich terenów mobilizacyjnych, natomiast znaczące różnice zachodziły w przypadku k.u. 9 i 11 LIR, gdzie podana przez Ehnla struktura językowa obu pułków znacząco różniła się od kompozycji językowej okręgów mobilizacyjnych obu jednostek.

W związku z powyższym możemy założyć, że k.u. 97 LstIBrig w większości składała się z żołnierzy narodowości węgierskiej. Bezsprzecznie stanowili oni większość w 10 pułku, w 11 ok. 2/3, w pozostałych zaś mogli stanowić około połowy. Tu także jednak trudno stawiać konkretne tezy. W przypadku k.u. 16 LstIR, który przez pewien czas (od września 1914 do końca stycznia 1915 r.) służył w VII obwodzie obronnym i w którym Węgrzy powinni wg danych z tabeli stanowić nieco ponad połowę żołnierzy, mamy dwie, w zasadzie sprzeczne ze sobą informacje. Wg Ottona Stolza z k.k. LstLdschR Nr. II, który także stacjonował w VII obwodzie i miał styczność z żołnierzami tej jednostki, większość żołnierzy 16 pułku stanowili Słowacy, którzy nie potrafili posługiwać się językiem węgierskim i z tego powodu językiem komendy w jednostce był niemiecki ${ }^{69}$. $\mathrm{Z}$ drugiej strony Jan Jakub Stock, który pracował w kancelarii w kompleksie koszarowym w Pikulicach i także miał kontakt z żołnierzami tworzącymi załogę VII obwodu obronnego, nigdzie nie wspomniał, by zetknął się ze Słowakami, a pisał jedynie o Węgrach (i Niemcach z Tyrolu z k.k. LstLdschR Nr. II) ${ }^{70}$. Być może wynikało to

\footnotetext{
${ }^{69}$ O. Stolz, op. cit., s. 181.

${ }^{70}$ J. J. Stock, Notatnik z Twierdzy Przemyśl 1914-1915, Przemyśl 2014, s. 51.
} 
stąd, że z racji pełnionych obowiązków raczej obracał się on w środowisku podoficerów i oficerów i nie miał na co dzień styczności z szeregowymi żołnierzami.

Należy bowiem podkreślić, że w jednostkach pochodzących z Węgier niezależnie od składu narodowościowego żołnierzy, ich oficerowie byli w przeważającej mierze narodowości węgierskiej, choć i tu zdarzały się wyjątki. Kadra oficerska tych jednostek tworzona była w oparciu o odpowiednie jednostki Honwedu, ale też pułków armii wspólnej stacjonujących na Węgrzech ${ }^{71} ; \mathrm{w}$ tym ostatnim przypadku znajomość języka węgierskiego nie musiała być regułą. Znamiennym przykładem był Rezső Almoslinó, ppor. rezerwy w c. i k. 23 Pułku Piechoty z Zombor, który w Przemyślu służył w k.u. 11 LstIR. W niewoli rosyjskiej przebywał w Taszkiencie, gdzie redagował pismo przeznaczone dla jeńców węgierskich „Turkeszáni Az Est”. Ponieważ niezbyt dobrze władał językiem węgierskim, za to dobrze rosyjskim i niemieckim, przy redagowaniu gazety przekładał on teksty z rosyjskiego na niemiecki, później zaś tłumaczono je na węgierski ${ }^{72}$.

Zamykając kwestię struktury narodowościowej jednostek piechoty walczących w Twierdzy Przemyśl, należy zwrócić uwagę na jeszcze jedną rzecz. Wspomniano na początku, że bataliony obrony krajowej i pospolitego ruszenia liczyły nieco ponad 1000 żołnierzy i oficerów. Teoretycznie więc 68 i pół batalionu, które znalazły się w twierdzy na początku II oblężenia, powinno stanowić ok. 70000 żołnierzy i oficerów. Pamiętać jednak należy, że jednostki te poniosły ciężkie straty w walkach w Galicji Wschodniej na przełomie sierpnia i września 1914 r. i w Przemyślu znalazły się znacznie zdekompletowane. 5 batalionów k.k. 108 LstIBrig liczyło 18 września po około 700 ludzi $^{73}$, w tym: k.k. LstLdschR Nr. II 1656 żołnierzy i 40 oficerów, zaś k.k. 21 LstIR 1900 żołnierzy ${ }^{74}$. Licząca 12 batalionów kk. 93 LstIBrig swe straty 15 września szacowała na 122 oficerów i 4400 żołnierzy $^{75}$, a zatem ponad $1 / 3$ stanu osobowego.

K.u. 97 LstIBrig tylko 1 września w bitwie pod Kulikowem straciła w zabitych i rannych 76 oficerów i 2485 żołnierzy ${ }^{76}$, co stanowiło ponad $20 \%$ jej stanu. Straty w k.u. 10 LstIR były wyższe od tej wartości: dowódca jednostki, płk. Viktor Arlow oceniał je na 26 oficerów, 847 żołnierzy ${ }^{77}$, zaś dowodzący II batalionem oficer na 26 oficerów i 1200 żołnierzy ${ }^{78}$.

\footnotetext{
${ }^{71}$ Świadczy o tym chociażby skład korpusu oficerskiego k.u. LstIR 10, zob. I. Miklauzič, Kard és fátyol. Lovag Arlow Viktor ezredes Przemyśl-Vladivosztok-Györ, Budapest 2015, s. 27-28.

${ }^{72}$ Schematismus für das k.u.k. Heer und für die k.u.k. Kriegsmarine für 1914, Wien 1914, s. 287; B. Fábián, 6 ló - 40 ember: hadifogoly feljegyzések, Budapest [1930], s. 117, 135.

${ }^{73}$ F. Conrad v. Hötzendorf, Aus meiner Dienstzeit 1906-1918, 4. Bd., 24. Juli 1914 bis 30. September 1914, Die politischen und militärischen Vorgänge vom Fürstenmord in Sarajevo bis zum Abschluß der zweiten Offensive gegen Serbien und Rußland, Wien 1923, s. 802.

${ }^{74}$ O. Stolz, op. cit., s. $160-161$.

${ }^{75}$ F. Conrad v. Hötzendorf, Aus meiner Dienstzeit 1906-1918, 4. Bd., s. 766.

${ }^{76}$ D. Nónay, op. cit., s. 22.

${ }^{77}$ I. Miklauzič, op. cit., s. 43.

${ }^{78}$ Dziennik oficera Landsturmu, Przemyśl 2004, s. 49.
} 
Wysokie straty były w k.u. 23 LITD. K.u. 5 LIR stracił w Galicji Wschodniej $60 \%$ oficerów i żołnierzy, w związku z czym po przybyciu do Przemyśla z 12 kompanii (każda liczyła na początku wojny ok. 263 żołnierzy) sformowano pięć ${ }^{79}$, a zatem pułk liczył w połowie września ok. 1300 żołnierzy.

O ile straty załogi twierdzy w czasie I oblężenia były stosunkowo niewielkie (dane wahają się między 952 - w tym 212 zabitych $^{80}$, a 1883 - w tym 313 zabitych, uwzględniając wypady załogi twierdzy we wrześniu i październiku ${ }^{81}$ ), to ponownie duże straty k.u. 23 LITD poniosła w październiku 1914 r. w czasie walk w okolicy wzgórza Magiera. Przykładowo II batalion k.u. 7 LIR 16 października liczył 830 karabinów, 5 listopada 264 karabinów ${ }^{82}$. W końcu października k.u. 2 LIR liczył 1285 żołnierzy, k.u. 7 LIR - 1121 (w rzeczywistości więcej, brak bowiem danych dla jednej kompanii), k.u. 8 LIR - 1686 żołnierzy. I baon k.u. 3 MarschIR liczył 492 żołnierzy ${ }^{83}$. Z drugiej strony we wrześniu i październiku straty uzupełniono, tak że w połowie października w k.u. 5 LIR udało się osiągnąć pełny stan w kompaniach (263 żołnierzy) ${ }^{84}$. Część uzupełnień pochodziła z rozwiązanego we wrześniu i październiku k.u. 6 MarschIR, ale część stanowiły inne jednostki i trudno ustalić, skąd konkretnie one pochodziły. Znamienny jest przykład uzupełnienia 5 pułku w dniu 23 września kompanią 274 żołnierzy z k.węg. 13 Pułku Piechoty Honwedu, dowodzoną przez por. Sándora Adamkovicsa. Oddział ten przybył do Przemyśla 16 września ${ }^{85}$. Pełny skład kompanii świadczy, że raczej nie była to jednostka, która walczyła wcześniej w Galicji Wschodniej, ale trafiła do twierdzy z głębi monarchii.

Pomiędzy I a II oblężeniem do Przemyśla starano się też uzupełnić straty w jednostkach walczących w Przemyślu poprzez przysyłanie batalionów marszowych uzupełnianych w okręgach mobilizacyjnych ${ }^{86}$ (4 bataliony marszowe dla k.u. 23 LITD i $3 \frac{1 / 4}{4}$ batalionu marszowego dla k.u. 97 LstIBrig). Jednakże bataliony marszowe 23 dywizji nie dotarły na miejsce, zaś 97 brygada otrzymała jedynie część uzupełnień ${ }^{87}$.

${ }^{79}$ D. Nónay, op. cit., s. 68.

${ }^{80}$ S. Nielipowicz, Krwawy październik 1914, t. 2, Oświęcim 2015, s. 32.

${ }^{81}$ B. Geőcze, op. cit., s. 53.

82 J. Gabány, op. cit., s. 570.

${ }^{83}$ B. Geőcze, op. cit., s. 66.

${ }^{84}$ D. Nónay, op. cit., s. 84.

${ }^{85}$ A volt m. kir. szegedi 5-ös honvédek: világháborus emlékalbuma, összeáll. B. Réti, Szeged 1933, s. 118.

${ }^{86}$ System batalionów marszowych polegał na tym, że zmobilizowanych w czasie wojny przydzielano do jednostek uzupełniających zlokalizowanych przy garnizonach pokojowych wszystkich jednostek. Tam ich szkolono i formowano w oddziały marszowe, które były stopniowo wysyłane na front w celu uzupełnienia strat w walczących jednostkach macierzystych (w warunkach wojennych nie zawsze jednak było to regułą), zob. F. Conrad v. Hötzendorf, Aus meiner Dienstzeit 1906-1918, 5. Bd., s. 698.

${ }^{87}$ F. Stuckheil, op. cit., s. 44-45. Jednak w czasie walk o wzgórze Magiera walczące tam jednostki wchodzące w skład k.u. 23 LITD zostały zasilone uzupełnieniami przesłanymi z garnizonów pokojowych: 20 października przybył w ten rejon k.węg. 50 Batalion Marszowy z uzupełnieniami dla k.u. 2 LIR, zob. J. Gabányi, op. cit., s. 562; o przybyciu tego rodzaju uzupełnień do walczących w tym rejonie oddziałów informował też podwładnych w rozkazie z 30 października płk. Gyula Létay, zob. MNZP. ApEM, Teka 4, sygn. MP-Hist. 391, k. 81-82. 
Pytanie tylko, czy rzeczywiście te jednostki były mobilizowane wyłącznie w macierzystych okręgach mobilizacyjnych. Dowódca k.u. 10 LstIR w swym dzienniku zapisał, że 6 listopada 1914 r. przybyło do jego pułku jako uzupełnienie 14 oficerów i 864 żołnierzy, wśród nich 89 Rusinów z Máramaros ${ }^{88}$. Rejon ten nie znajdował się w obrębie okręgu mobilizacyjnego k.u. 10 LIR.

Należy też zwrócić uwagę na jeszcze jeden czynnik, który mógł wpływać na skład garnizonu twierdzy, a także na kompozycję narodowościową poszczególnych jednostek.

Od wybuchu wojny Przemyśl, jako kluczowy węzeł komunikacyjny w środkowej części Galicji, był punktem etapowym dla znaczniej części 3 Armii, ale też dla 4 i 2 Armii austro-węgierskiej. Kilkakrotnie przez samo miasto lub jego okolice przetoczyły się masy wojska - raz w czasie koncentracji we Wschodniej Galicji, drugi raz - w czasie wrześniowego odwrotu, trzeci raz - w czasie odblokowania twierdzy na początku października i czwarty raz - w czasie listopadowego odwrotu. Nie zawsze ten ruch był uporządkowany czy kontrolowany - szczególnie w połowie września 1914 r., gdy Przemyśl zaroił się od setek żołnierzy z rozmaitych pułków wycofującej się w nieładzie 3 Armii $^{89}$. Maruderzy, jeśli nie można było odesłać ich do macierzystych jednostek, siłą rzeczy przydzielani byli do jednostek garnizonu. Trafiali do nich też ozdrowieńcy z przemyskich szpitali. Tych wprawdzie starano odsyłać się na tyły, ale wraz z początkiem II oblężenia było to niemożliwe. W sumie można tu brać pod uwagę nawet kilka tysięcy żołnierzy - w przemyskich szpitalach przygotowanych było na początku wojny 8000 miejsc, ta liczba w okresie bitwy nad Sanem (październik 1914 r.) wzrosła do $12000^{90}$. Niekiedy udział rekonwalescentów w pododdziałach był znaczny - V. Mészáros wspominał, że do jego 7 kompanii k.u. 16 LstIR jesienią 1914 r. przydzielono trzech zapasowych rezerwistów z Honwedu (Węgrów) oraz 70 Bośniaków (czyli Serbów, ewentualnie Chorwatów). Wśród tych ostatnich tylko jeden rozumiał po niemiecku, z pozostałymi kontakt był praktycznie niemożliwy ${ }^{91}$. Ponadto do kompanii przydzielono też dwóch Galicjan, którzy zresztą przy pierwszej okazji zdezerterowali ${ }^{92}$. Nie wiadomo, na ile była to sytuacja powszechna i jak wyglądały

${ }^{88}$ I. Miklauzič, op. cit., s. 62.

${ }^{89}$ B. Geöcze, op. cit., s. 27.

${ }^{90}$ Ibidem, s. 22.

${ }^{91}$ V. Mészáros, Húsz évvel ezelött... Kis epizódok a nagy háborúból, VIII, Przemyśl vára az ostrom alatt, „Győri Hírlap”, R. 78, nr 244 z 28 października 1934 r., s. 4. Mészáros nie wyjaśnił, skąd pochodzili ci Bośniacy. Aczkolwiek w Twierdzy Przemyśl w czasie I i II oblężenia nie walczył żaden oddział z Bośni i Hercegowiny, to jednak w czasie walk w okolicy wzgórza Magiera w grupie, którą dowodził ppłk. Elek Molnár, znalazł się II batalion c. i k. 2 Pułku Bośniacko-Hercegowińskiego (k.u.k. bh 2 IR). Batalion ten na początku listopada 1914 r. wraz z pozostałymi oddziałami należącymi do tej grupy (jednostki z k.u. 2, 7 i 8 LIR, 3 MarchIR) na początku listopada wycofał się do Przemyśla. W tym czasie liczył ok. 300 żołnierzy. Nie wiadomo, czy został wycofany z Przemyśla (wraz z przybyciem jednostek k.u. 23 LITD spod Magiery zaczęło się II oblężenie), czy może został rozformowany i wcielono jego żołnierzy do innych jednostek. K.u.k. bh 2 IR mobilizowany był w okolicach Banjaluki w centralnej Bośni, zob. MNZP. ApEM, Teka 4, sygn. MP-Hist. 391, k. 102, 103, 213, 223; M. Ehnl, op. cit., s. 40; B. Geöcze, op. cit., s. 66.

${ }_{92}$ V. Mészáros, Húsz évvel ezelött... Kis epizódok a nagy háborúból, IX, Przemyśl vára az ostrom alatt, „Győri Hírlap”, R. 78, nr 248 z 4 listopada 1934 r., s. 5. 
proporcje w pozostałych przypadkach, z pewnościąjednak podobne uzupełnienia miały miejsce także w innych jednostkach, o czym wspominał też O. Stolz w przypadku k.k. LstLdschIR Nr. II ${ }^{93}$. Niewątpliwie takie sytuacje niekiedy - jak wynika z przykładu 7 kompanii k.u. 16 LstIR, gdzie nowo przybyli żołnierze stanowili ponad $1 / 4$ oddziału znacznie wpływały na skład narodowościowy uzupełnianych w ten sposób jednostek.

Być może, w czasie przemarszu przez Przemyśl zostawały tu też całe pododdziały czy oddziały. Znamienny jest przykład c.k. 4 Pułku Pospolitego Ruszenia (k.k. 4 LstIR). Żadne zestawienie nie wymienia tej jednostki w składzie garnizonu twierdzy. Jednakże w swym dzienniku lekarz w Szpitalu Twierdzy nr 4, doktor Richard v. Stenitzer wspominał, że obsadę rdzenia twierdzy w okolicy drogi na Ostrów stanowili żołnierze z tej właśnie jednostki ${ }^{94}$. K.k. 4 LstIR, mobilizowany był w okolicy Klagenfurtu ${ }^{95}$, wchodził w skład c.k. 105 Brygady Pospolitego Ruszenia (k.k. 105. LstIR), która wchodziła w skład 2 Armii i która we wrześniu, październiku i listopadzie 1914 r. walczyła we Wschodniej Galicji (na przełomie października i listopada w okolicy Chyrowa) ${ }^{96}$. Nie jest więc wykluczone, że część k.k. 4 LstIR mogła rzeczywiście trafić do Przemyśla i zostać przydzielona do grupy gen. Wilhelma Nickla, która stanowiła obsadę rdzenia twierdzy, a na którą składały się zgromadzone ad hoc oddziały różnego autoramentu.

W świetle obecnie dostępnych źródeł i opracowań nie wiadomo, ile rozmaitych drobniejszych oddziałów czy nawet pojedynczych żołnierzy dotarło do twierdzy w okresie od połowy września do początku listopada 1914 r., w jakim stopniu uzupełniono nimi straty w przemyskich jednostkach, ale niewątpliwie wraz z ich napływem i włączaniem do jednostek zmianie mogły ulegać też stosunki narodowościowe w obrębie uzupełnianych oddziałów.

O ile skład narodowościowy oddziałów piechoty możemy podać jedynie w dużym przybliżeniu, to jeszcze mniej precyzyjnych danych mamy dla pozostałych jednostek, które służyły w Twierdzy Przemyśl. Należały do nich oddziały artylerii, jednostki jazdy, oddziały robocze, wreszcie rozmaite instytucje zaplecza twierdzy.

W Twierdzy Przemyśl znajdowały się 43 kompanie należące do pułków artylerii fortecznej, batalionów artylerii fortecznej oraz oddziały artylerii pospolitego ruszenia. Jedynymi jednostkami artylerii polowej były k.węg. 2 Pułk Armat Polowych Honwedu (k.u. 2 LFKR) oraz rezerwowe baterie c. i k. 30 i 41 Pułku Armat Polowych.

W przypadku pułków artylerii fortecznej w Przemyślu służyły: cały c. i k. 3 Pułk Artylerii Fortecznej (k.u.k. 3 FstAR, Przemyśl), IV batalion c. i k. 1 Pułku Artylerii

${ }^{93}$ O. Stolz, op. cit., s. 192.

${ }^{94}$ R. Stenitzer, Belegerung und Gefangenschaft: von Przemyśl bis Russisch Turkestan: das Kriegstagesbuch des Dr. Richard Ritter von Stenitzer 1914-1917, Graz 2010, s. 57.

${ }^{95}$ Większość żołnierzy tego oddziału stanowili Niemcy; dla porównania - w c.k. 4 Pułku Piechoty Landwehry latem 1914 r. 79\% żołnierzy posługiwało się językiem niemieckim, 21\% - innym (zob. M. Ehnl, op. cit., s. 74). Owe $21 \%$ stanowili w przeważającej większości żołnierze posługujący się językiem słoweńskim, gdyż na podstawie danych ze spisu 1910 r. około 20\% mieszkańców Karyntii posługiwało się tym właśnie językiem, zob. Die Ergebnisse der Volkszählung, s. 59*.

${ }^{96}$ ÖULK, 1, s. 73, 213, 217, 243, 244, 248, 249, 252, 285, 393, 418, 475, 508, 565-566, 568-569. 
Fortecznej (k.u.k. 1 FstAR, Wiedeń) oraz jeden batalion z c. i k. 6 Pułku Artylerii Fortecznej (k.u.k. 6 FstAR, Budapeszt), ponadto oddziały oświetleniowe z k.u.k. 1 i 3 FstAR, po jednym oddziale balonów obserwacyjnych z k.u.k. 1, 2, 3 FstAR ${ }^{97}$. Skład językowy wszystkich tych jednostek (całych) latem 1914 r. przedstawiał się następująco:

Tabela 8. Struktura językowa k.u.k. 1, 2, 3 i 6 FstAR.

\begin{tabular}{|l|c|c|c|c|c|c|c|}
\hline & $\begin{array}{c}\text { Uzupełniany } \\
\text { w obrębie } \\
\text { korpusu: }\end{array}$ & $\begin{array}{c}\text { Język } \\
\text { niemiecki } \\
(\%)\end{array}$ & $\begin{array}{c}\text { Język } \\
\text { węgierski } \\
(\%)\end{array}$ & $\begin{array}{c}\text { Język } \\
\text { czeski } \\
(\%)\end{array}$ & $\begin{array}{c}\text { Język } \\
\text { polski } \\
(\%)\end{array}$ & $\begin{array}{c}\text { Język } \\
\text { ukraiński } \\
(\%)\end{array}$ & $\begin{array}{c}\text { Inny } \\
\text { język } \\
(\%)\end{array}$ \\
\hline K.u.k. 1 FstAR & II (Wiedeń) & 74 & - & 23 & - & - & 3 \\
\hline K.u.k. 2 FstAR & I (Kraków) & 32 & - & 27 & 38 & - & 3 \\
\hline K.u.k. 3 FstAR & XI (Lwów) & - & - & - & 25 & 50 & 25 \\
\hline K.u.k. 6 FstAR & V (Pozsony) & 24 & 54 & - & - & - & 22 \\
\hline
\end{tabular}

Źródło: M. Ehnl, op. cit., s. 63-64.

Nie sposób jednak powiedzieć, jakie były proporcje narodowościowe w pojedynczych batalionach 1 i 6 pułku oraz oddziale balonów obserwacyjnych 2 pułku, które służyły w Przemyślu.

W Przemyślu znajdowały się też kompanie z c. i k. 3 Batalionu Artylerii Fortecznej (k.u.k. 3 FstAB, Pola), c. i k. 9 Batalionu Artylerii Fortecznej (k.u.k. 9 FstAB, Lwów) i c. i k. 10 Batalionu Artylerii Fortecznej (k.u.k. 10 FstAB, Görz) oraz oddział reflektorów z k.u.k. 9 FstAB ${ }^{98}$. Struktura językowa całych batalionów latem 1914 r. wyglądała następująco:

Tabela 9. Struktura językowa k.u.k. 3, 9 i 10 FstAB.

\begin{tabular}{|l|c|c|c|c|c|c|}
\hline & $\begin{array}{c}\text { Uzupełniany } \\
\text { w obrębie } \\
\text { korpusu: }\end{array}$ & $\begin{array}{c}\text { Język } \\
\text { niemiecki } \\
(\%)\end{array}$ & $\begin{array}{c}\text { Język } \\
\text { węgierski } \\
(\%)\end{array}$ & $\begin{array}{c}\text { Język } \\
\text { czeski } \\
(\%)\end{array}$ & $\begin{array}{c}\text { Język } \\
\text { słoweński } \\
(\%)\end{array}$ & $\begin{array}{c}\text { Inny } \\
\text { język } \\
(\%)\end{array}$ \\
\hline K.u.k. 3 FstAB & V (Pozsony) & 40 & 32 & - & 23 & 5 \\
\hline K.u.k. 9 FstAB & VIII (Praga) & 35 & - & 60 & - & 5 \\
\hline K.u.k. 10 FstAB & II (Wiedeń) & 68 & - & 28 & - & 4 \\
\hline
\end{tabular}

Źródło: M. Ehnl, op. cit., s. 64-65.

Na pierwszy rzut oka zaskakujący może się wydawać odsetek żołnierzy mających posługiwać się językiem słoweńskim w k.u.k. 3 FstAB, uzupełnianym na zachodzie Królestwa Węgierskiego, w obrębie V Korpusu, obejmującego też znaczne tereny dzisiejszej Słowacji. To mogłoby sugerować, że pomylono język słoweńskim

\footnotetext{
${ }^{97}$ B. Geőcze, op. cit., załącznik nr 1.

${ }^{98}$ Ibidem.
} 
ze słowackim. Jednak batalion ten swą siedzibę miał w Pola i przydzielony był do III Korpusu (Graz) ${ }^{99}$, który również obejmował Krainę, czyli dzisiejszą Słowenię oraz Styrię, w ówczesnych granicach zamieszkaną przez znaczny odsetek ludności słoweńskiej. Stąd też mogła wynikać obecność w tej jednostce większej liczby żołnierzy posługujących się językiem słoweńskim. O tym, że w Twierdzy Przemyśl służyła znacząca liczba artylerzystów narodowości słoweńskiej, informowała w październiku prasa słoweńska, wedle której ponad 1000 Słoweńców służyło $\mathrm{w}$ tym rodzaju broni ${ }^{100}$. Aczkolwiek dane zawarte w prasie należy traktować z dużą ostrożnością, to jednak wskazują one, że w artylerii Twierdzy Przemyśl obecna była całkiem spora liczba Słoweńców. Najprawdopodobniej nie tylko w kompaniach wchodzących w skład pułków i batalionów artylerii fortecznej w Twierdzy Przemyśl, ale też $\mathrm{w}$ oddziałach artylerii pospolitego ruszenia. W tym przypadku tych jednostek nie posiadamy pełnych informacji co do ich pochodzenia, składu narodowościowego ani nawet liczby (48 lub 49, jak zaznaczono na wstępie).

$\mathrm{Z}$ danych zawartych w Kriegsgliederung der Besatzung... wynika, że w Twierdzy Przemyśl służyło 40 jednostek oznaczonych jako Lst.Art.Abt.: k.k. 1-7, 23, 24/2, 1-12/2, 1, 9/10, 11, 12, 13/11, 1-6/14 oraz k.u. 5-7, 11-15/IV.

$\mathrm{Z}$ zestawienia tego wynika, że 32 oddziały pochodziły z Przedlitawii, osiem z Węgier.

Być może przedlitawskie oddziały tworzone były w oparciu o okręgi uzupełnień Landwehry. Bliższe dane mamy tylko dla dwóch takich oddziałów (Landsturm-Artilerie-Abteilung Nr. 1 i 2), utworzonych w okręgu pospolitego ruszenia nr 2 w Linzu z ekspozyturą w Salzburgu (okręg uzupełnień c.k. 2 Pułku Piechoty Landwehry). Liczyły one w sumie 2 oficerów i 200 żołnierzy ${ }^{101}$. Te dwa oddziały mobilizowane w Salzburgu i Górnej Austrii (wg danych ze spisu z 1910 r. prawie $100 \%$ mieszkańców obu tych krajów koronnych było Niemcami ${ }^{102}$ ) siłą rzeczy musiały się składać w przeważającej większości z Niemców.

W tabeli brakuje jednostek przedlitawskich oznaczonych cyfrą (czy symbolem) /3, tymczasem wiadomo, że w twierdzy służył oddział k.k. Landsturm Artillerie Abteilung Nr. $3 / 3$ z Grazu (świadczy o tym zamieszczony w „Kriegsnachrichten” wiersz „Die Steier”, w którym wspomniano m.in. o styryjskich landszturmistach służących w Przemyślu ${ }^{103}$ oraz k.k. Landsturm Artillerie Abteilung Nr. 4/3, którego artylerzysta Franz Schmidt opublikował w tymże dzienniku wiersz „Der Älperlandsturm!”104.

${ }^{99}$ M. Ehnl, op. cit., s. 64; Schematismus für das k.u.k. Heer, Wien 1914, s. 921.

100 „Novi Čas”, R. 5, nr 43 z 22 października 1914 r., s. 3.

${ }^{101}$ Der Heldenweg des Zweier-Landsturm 1914-1918: Geschichte des oberösterreichisch-salzburgischen k.k. Landsturm-Infanterieregiments Nr. 2 und der selbständigen Landsturm-Feldbataillone, Linz [1937], s. 14.

${ }^{102}$ Die Ergebnisse der Volkszählung, s. 59*.

103 „Kriegsnachrichten”, nr 118 z 15 lutego 1915 r., s. 1.

104 „Kriegsnachrichten”, nr 115 z 12 lutego 1915 r., s. 1. 
Być może oddziały 1-12/2 zostały w zestawieniu AOK mylnie oznaczone ${ }^{105}$ i chodzi $\mathrm{w}$ istocie o jednostki 1-12/3, które mogły być tworzone w okręgu mobilizacyjnym c.k. 3 Pułku Piechoty Landwehry z siedzibą w Grazu, który obejmował ówczesną północną Styrię. W takim wypadku byliby to żołnierze pochodzący z terenów w przeważającej części niemieckojęzycznych; wśród żołnierzy c.k. 3 Pułku Piechoty Landwehry w 1914 r. 94\% mówiło językiem niemieckim, pozostałe 6\% - innym. Zważywszy na skład narodowościowy Styrii, byli to głównie Słoweńcy.

Jeśli pozostałe przedlitawskie oddziały artylerii pospolitego ruszenia były tworzone w podobny sposób, to mielibyśmy do czynienia z żołnierzami pochodzącymi z terenów mobilizacyjnych c.k. 10, 11 i 14 Pułku Piechoty Landwehry: Jungbunzlau/Mladá Boleslav i Jičin w Czechach oraz Brünn/Brno na Morawach. Kwestię składu narodowościowego obszaru mobilizacyjnego k.k. 10 LIR przedstawiono już wyżej; w przypadku terenów uzupełnień dwóch pozostałych pułków, to były to obszary o ludności niemiecko- i czeskojęzycznej. Skład językowy obu pułków w 1914 r. przedstawiał się następująco: w k.k. 11 LIR językiem czeskim posługiwało się $63 \%$, niemieckim - 36\%, innym - 1\%, w k.k. 14 LIR - czeskim $67 \%$, niemieckim $31 \%$, innym $-1 \%{ }^{106}$.

W przypadku jednostek węgierskich (k.u. 5-7, 11-15/IV) trudno dostrzec prawidłowość powiązania poszczególnych oddziałów z okręgami mobilizacyjnymi poszczególnych pułków obrony krajowej. Pewnych ogólnych informacji dostarcza zamieszczone w wydawanym w Nagykanizsa dzienniku „Zala” pozdrowienia dla żołnierzy pochodzących z okolic Nagykanizsa (komitat Zala), wziętych do niewoli w Przemyślu. Wśród wymienionych w pozdrowieniach żołnierzy wielu służyło w jednostce oznaczonej Landst. Art. Abt. 13/IV (sporo z tych wiadomości odnosi się też do artylerzystów z k.u.k. 6 FstAR oraz k.u.k. 3 FstAB) ${ }^{107}$. Wg danych ze spisu z 1910 r. 74,4\% mieszkańców tego komitatu posługiwało językiem węgierskim, $19,6 \%$ - chorwackim, pozostałe $6 \%$ - innym (w samym Nagykanizsa oraz przynależącym doń powiecie odsetek ludności węgierskiej sięgał $90 \%$, chorwackiej $7 \%{ }^{108}$ ).

Być może oznaczenie /IV odnosi się do IV Okręgu Honwedu ${ }^{109}$, obejmującego zachodnią część Węgier, na terenie którego leżał też komitat Zala. Brak jednak informacji pozwalających potwierdzić tę tezę i powiązać pozostałe oddziały z tej grupy z określonym terytorium Królestwa Węgierskiego.

${ }^{105}$ Zestawienie ma formę tabeli, jednostki oznaczone jako k.k. Lst.Art.Abt.: 1-7, 23, 24/2, 1-12/2, $1,9 / 10,11,12,13 / 11,1-6 / 14$ znajdują się w następujących po sobie pięciu wierszach.

${ }^{106}$ M. Ehnl, op. cit., s. 75.

107 „Zala”, R. 42, nr 74 z 3 kwietnia 1915 r., s. 3-5.

${ }^{108}$ A Magyar Szent Korona, 96-97.

${ }^{109} \mathrm{~W}$ chwili wybuchu wojny terytorium Królestwa Węgier podzielone było na 6 okręgów Honwedu (I Budapeszt, II Segedyn, III Kassa, IV Pozsony, V Kolozsvár, VI Zagrzeb). Ten podział pokrywał się z podziałem Węgier na okręgi korpusów armii wspólnej (IV Budapeszt, V Pozsony, VI Kassa, VII Temesvár, XII Nagyszeben, XIII Zagrzeb) z tym że - jak siedziba okręgu Honwedu nie zawsze była tożsama z siedzibą okręgu korpusu armii wspólnej (Segedyn zamiast Temesvár oraz Kolozsvár zamiast Nagyszeben). 
Nic nie wiadomo też o pozostałych ośmiu (lub dziewięciu) oddziałach artylerii pospolitego ruszenia.

Struktura językowa k.u. 2 LFKR w końcu czerwca 1914 r. w opracowaniu M. Ehnla została przedstawiona następująco: niemiecki $-26 \%$, rumuński $-69 \%$, inny $-6 \%{ }^{110}$. Jednakże Ehnl błędnie podał, że pułk uzupełniano w V Okręgu Honwedu ${ }^{111}$, obejmującym Siedmiogród. Nie wiadomo, skąd te dane zostały zaczerpnięte (taka dyslokację podano też w Seidels kleines Armeeschema) ${ }^{112}$. Pochodzenie jednostki z Siedmiogrodu wyjaśniałoby wysoki odsetek żołnierzy posługujących się językiem rumuńskim, jednakże w rzeczywistości pułk uzupełniany był w II Okręgu Honwedu, zaś jego miastem garnizonowym był Versecz ${ }^{113}$.

Sporo informacji o pochodzeniu żołnierzy służących w k.u. 2 LFKR znajdujemy w „Listach Strat”. Wedhug zawartych w nich danych w k.u. 2 LFKR dominowali żołnierze pochodzący z komitatów (całych lub części) Arad, Békés, Bihar, Csanád, Csongrád, Hajdu, Krassó-Szörény, Temes, Torontál. A to oznaczałoby, że służyli w nim żołnierze mobilizowani na terenie II Okręgu Honwedu. W dużej mierze był to rejon uzupełnień pułków k.u. 23 LITD, a więc znaczący musiał być w k.u. 2 LFKR odsetek Rumunów, Serbów i Niemców. Z drugiej strony w porównaniu z 23 dywizją w pułku większy być powinien odsetek żołnierzy narodowości węgierskiej, szczególnie pochodzących z komitatu Hajdu, który w niemalże 100\% zamieszkany był przez ludność węgierską ${ }^{114}$ (w komitacie Bihar Węgrzy stanowili nieco ponad 57\%, Rumuni 41,4\% ${ }^{115}$ ). Początkowo pułk składał się z trzech baterii, każda z nich liczyła sześciu oficerów, jednego chorążego i 167 żołnierzy ${ }^{116}$, w sumie więc cały k.u. 2 LFKR liczył początkowo ok. 522 żołnierzy i oficerów. Po 20 września 1914 r., już w Przemyślu, do pułku dodano rezerwową baterię armat z c. i k. 30 Pułku Armat Polowych (k.u.k. 30 FKR) ${ }^{117}$ jako 4 baterię, która składała się z żołnierzy polskich i ukraińskich oraz austriackich (niemieckich) oficerów ${ }^{118}$. K.u.k. 30 FKR mobilizowany był w okręgu X Korpusu (Przemyśl) i latem 1914 r. w większości (66\%) składał się z żołnierzy posługujących się językiem ukraińskim.

\footnotetext{
${ }^{110}$ M. Ehnl, op. cit., s. 91.

${ }^{111}$ Ibidem.

${ }^{112}$ Seidels kleines Armeeschema: Dislokation und Einteilung des k.u.k. Heeres, der k.u.k. Kriegsmarine, der. k.k. Landwehr und der königlich ungarischen Landwehr (Abgeschlossen mit 5. August 1914), Wien 1914, s. 178.

${ }^{113}$ L. Thaisz, Honvédtüzérek Przemyślben, „Hadtörténelmi Közlemények”, t. 27 (1926), s. 481; T. Balla, A magyar királyi Honvéd Tüzérség 1912-1914. I. rész, „Hadtorténelmi Közlemények”, R. 106, nr 3 (1993), s. 34; T. Balla i in., The history of the Hungarian artillery 1913-2013, Budapest cop. 2015 , s. 98.

${ }^{114}$ A Magyar Szent Korona, s. 298-299.

${ }^{115}$ Ibidem, s. 296-297.

${ }^{116}$ T. Balla, A magyar királyi Honvéd Tüzérség 1912-1914. II. rész, „Hadtorténelmi Közlemények", R. 106 (1993), s. 71-72.

${ }^{117}$ Wg W. Gorgosza stanowiła artylerię k.k. 111 LstIBrig, zob. W. Gorgosz, op. cit., tabl. II.

${ }^{118}$ L. Thaisz, op. cit., s. 485.
} 
Pozostałe 34\% deklarowało używanie innego języka ${ }^{119}$. Zważywszy na powyższe dane można stwierdzić, że k.u. 2 LFKR składał się żołnierzy narodowości węgierskiej, rumuńskiej, serbskiej, niemieckiej - w trudnych do ustalenia proporcjach, ze sporym odsetkiem Ukraińców. Korpus oficerski stanowili - jak we wszystkich jednostkach Honwedu - Węgrzy, ale też Niemcy i Rumuni.

Rezerwowa bateria c. i k. 41 Pułku Armat Polowych mobilizowana była najprawdopodobniej w okręgu uzupełnień macierzystej jednostki, czyli w rejonie Salzburga (wg W. Gorgosza staniowiła artylerię k.k. 108 LstIBrig ${ }^{120}$ ). Stąd zapewne 98\% jej żołnierzy posługiwało się językiem niemieckim ${ }^{121}$.

W wykorzystanych źródłach spotykamy rozbieżne informacje, co do ilości i rodzaju jednostek kawaleryjskich w twierdzy. Jeśli porównamy trzy podstawowe źródła i opracowania to otrzymamy następujące zestawienie:

Tabela 10. Zestawienie jednostek kawalerii służących w Twierdzy Przemyśl ujętych w pracach B. Geőczego i W. Gorgosza oraz w Kriegsgliederung der Besatzung....

\begin{tabular}{|l|l|l|}
\hline \multicolumn{1}{|c|}{$\begin{array}{c}\text { Kriegsgliederung } \\
\text { der Besatzung... }\end{array}$} & \multicolumn{1}{c|}{ B. Geöcze } & \multicolumn{1}{c|}{ W. Gorgosz } \\
\hline $\begin{array}{l}\text { I i II szwadron k.węg. 4 } \\
\text { Pułk Huzarów Honwedu }\end{array}$ & $\begin{array}{l}\text { I i II szwadron k.węg. } \\
\text { 4 Pułk Huzarów Honwedu }\end{array}$ & $\begin{array}{l}\text { I i II szwadron k.węg. } \\
\text { 4 Pułk Huzarów Honwedu }\end{array}$ \\
\hline $\begin{array}{l}\text { Szwadron rezerwowy } \\
\text { c. i k. 4 Pułku Ułanów }\end{array}$ & - & - \\
\hline $\begin{array}{l}\text { Szwadron rezerwowy } \\
\text { c. i k. 11 Pułku Ułanów }\end{array}$ & $\begin{array}{l}\text { Szwadron rezerwowy } \\
\text { c. i k. 11 Pułku Ułanów }\end{array}$ & $\begin{array}{l}\text { Szwadron rezerwowy } \\
\text { c. i k. 11 Pułku Ułanów }\end{array}$ \\
\hline $\begin{array}{l}\text { Szwadron c.k. 2 Dywizjo- } \\
\text { nu Kawalerii Tyrolskich } \\
\text { Strzelców Krajowych }\end{array}$ & - & $\begin{array}{l}\text { Szwadron c. k. 2 Dywizjo- } \\
\text { nu Kawalerii Tyrolskich } \\
\text { Strzelców Krajowych }\end{array}$ \\
\hline- & $\begin{array}{l}\text { Dywizjon Pospolitego } \\
\text { Ruszenia k.węg. 6 Pułku } \\
\text { Huzarów Honwedu }\end{array}$ & $\begin{array}{l}\text { Duszizon Pospolitego } \\
\text { Huzarów Hogn. 6 Pułku }\end{array}$ \\
\hline- & $\begin{array}{l}\text { Szwadron rezerwowy } \\
\text { c. i k. 6 Pułku Dragonów }\end{array}$ & - \\
\hline- & - & $\begin{array}{l}\text { Szwadron rezerwowy } \\
\text { 6 Pułku Huzarów }\end{array}$ \\
\hline
\end{tabular}

Źródło: Kriegsgliederung der Besatzung...; B. Geöcze, op. cit., załącznik nr 1; W. Gorgosz, op. cit. tabl. II.

Pomimo pewnej rozbieżności danych, z całą pewnością można stwierdzić, że kawalerię twierdzy stanowiły: I i II szwadron k.węg. 4 Pułk Huzarów Honwedu

\footnotetext{
${ }^{119}$ M. Ehnl, op. cit., s. 53.

${ }^{120} \mathrm{~W}$. Gorgosz, op. cit., tabl. II.

${ }^{121}$ M. Ehnl, op. cit., s. 55.
} 
(k.u. 4 LHR), Dywizjon Pospolitego Ruszenia k.węg. 6 Pułku Huzarów Honwedu (k.u. 6 LstHusDiv.) oraz szwadron rezerwowy c. i k. 11 Pułku Ułanów (k.u.k. 11 UR). Bardzo prawdopodobna jest obecność szwadronu 2 Dywizjonu Kawalerii Tyrolskich Strzelców Krajowych (2 Esk. rt LTsch), który - wedle zestawienia podanego przez Gorgosza - należał do k.k. 108 LstIBrig. Trudno rozstrzygnąć, czy w Twierdzy Przemyśl rzeczywiście przebywały pozostałe oddziały: szwadron rezerwowy c. i k. 4 Pułku Ułanów (k.u.k. 4 UR), szwadron rezerwowy c. i k. 6 Pułku Dragonów (k.u.k. 6 DR) i szwadron rezerwowy 6 Pułku Huzarów. W przypadku tego ostatniego, ze względu na sposób zapisu nazwy jednostki w opracowaniu Gorgosza (rez./6.p.huz. ${ }^{122}$ ), nie wiadomo, czy chodzi jednostkę związaną z k.u. 6 LstHusDiv., czy z c. i k. 6 Pułkiem Huzarów (k.u.k. 6 HR).

W przypadku k.u. 4 LHR struktura językowa całego pułku w czerwcu 1914 r. przedstawiała się następująco: węgierski - 76\%, chorwacki, serbski, serbochorwacki $20 \%$, inny $4 \%$. Pułk ten tworzony był w I Okręgu Honwedu ${ }^{123}$ (okręg IV Korpusu armii wspólnej), który obejmował centralne oraz południowe części ówczesnych Węgier. Opierając się na danych z „List Strat” można powiedzieć, że większość żołnierzy tego pułku pochodziła z komitatu Bács-Bodrog, którego ludność w 1910 r. składała się w 44\% z Węgrów, 23\% Niemców oraz 17\% Serbów ${ }^{124}$, mniejszość zaś z niemalże czysto węgierskiego komitatu Pest-Pilis-Solt-Kiskun (w 1910 r. ok. 90\% ${ }^{125}$ ) oraz z zamieszkanego w ponad 99\% przez ludność węgierskojęzyczną komitatu Jász-Nagykun-Szolnok ${ }^{126}$. Nie sposób ustalić, jaki był udział poszczególnych narodowości w służących w Twierdzy Przemyśl dwóch szwadronach tego pułku.

Drugą jednostką jazdy węgierskiej był k.u. 6 LstHusDiv. Podobnie jak jednostki pospolitego ruszenia piechoty, także jednostki pospolitego ruszenia jazdy tworzone były po ogłoszeniu mobilizacji w oparciu o istniejące już jednostki Honwedu. W przypadku jazdy każdy pułk huzarów wystawiał dywizjon pospolitego ruszenia, złożony z trzech szwadronów. K.węg. 6 Pułku Huzarów (k.u. 6 LHR) uzupełniany był w obrębie IV Okręgu Honwedu, a więc na terenie zachodnich Węgier. Nie mamy danych co do struktury językowej dywizjonu pospolitego ruszenia tego pułku, posiłkować się znów możemy jedynie danymi dotyczącymi k.u. 6 LHR, którego struktura językowa latem 1914 r. przedstawiała się następująco: węgierski $-55 \%$, niemiecki $-34 \%$, inny $-11 \%{ }^{127}$.

Dość niejasna sytuacja zachodzi w przypadku k.u.k. 11 UR. Wg „Schematyzmu" na rok 1914 r. uzupełniany był on w okręgach korpusów IX (Leitmeritz)

\footnotetext{
${ }^{122}$ W. Gorgosz, op. cit., tabl. II.

${ }^{123}$ M. Ehnl, op. cit., s. 90.

${ }^{124}$ A Magyar Szent Korona, s. 182-183.

${ }^{125}$ Ibidem, s. 198-199.

${ }^{126}$ Ibidem, s. 190-191.

${ }^{127}$ M. Ehnl, op. cit., s. 90.
} 
i X (Przemyśl) ${ }^{128}$. Według Ehnla mobilizowano go w obrębie korpusów IX (Leitmeritz) i XI (Lwów) i latem 1914 r. 65\% żołnierzy pułku deklarowało używanie języka czeskiego, pozostałe $35 \%$ języka niemieckiego ${ }^{129}$. Być może jednak w szwadronie służącym w Przemyślu struktura językowa była inna, bowiem w istocie mógł być on złożony z żołnierzy pochodzących ze wschodniej Galicji. To mógłby sugerować fakt, że wedle informacji podanych przez Gorgosza szwadron ten przynależał do k.k. 111 LstIBrig, a więc jednostki składających się z pułków mobilizowanych w środkowej i wschodniej Galicji, na terenie X i XI Korpusu.

W przypadku szwadronu z c.k. 2 Dywizjonu Kawalerii Tyrolskich Strzelców Krajowych, to cały dywizjon mobilizowany był w Okręgu Mobilizacyjnym Landwehry (Landwehrterritorialbereich) Innsbruck obejmującym Górną Austrię, Salzburg i Tyrol ${ }^{130}$. Latem 1914 r. jego struktura językowa przedstawiała się następująco: język niemiecki - 58\%, włoski $-38 \%$, inny $-4 \%{ }^{131}$.

W przypadku szwadronów, co do przebywania których w Twierdzy Przemyśl można mieć pewne wątpliwości (k.u.k. 4 UR, k.u.k. 6 DR, k.u.k. 6 HR), dane dla struktury językowej całych pułków prezentuje poniższa tabela:

Tabela 11. Struktura językowa k.u.k. 4 UR, 6 DR, 6 HR.

\begin{tabular}{|l|l|c|c|c|c|c|c|}
\hline & $\begin{array}{c}\text { Uzupełniany } \\
\text { w obrębie } \\
\text { korpusu }\end{array}$ & $\begin{array}{c}\text { Język } \\
\text { niemiecki } \\
(\%)\end{array}$ & $\begin{array}{c}\text { Język } \\
\text { węgierski } \\
(\%)\end{array}$ & $\begin{array}{c}\text { Język } \\
\text { czeski } \\
(\%)\end{array}$ & $\begin{array}{c}\text { Język } \\
\text { polski } \\
(\%)\end{array}$ & $\begin{array}{c}\text { Język } \\
\text { ukraiński } \\
(\%)\end{array}$ & $\begin{array}{c}\text { Inny } \\
\text { język } \\
(\%)\end{array}$ \\
\hline k.u.k. 4 UR & XI (Lwów) & - & - & - & $29 \%$ & $65 \%$ & $6 \%$ \\
\hline k.u.k. 6 DR & II (Wiedeń) & $38 \%$ & - & $61 \%$ & - & - & $1 \%$ \\
\hline k.u.k. 6 HR & VI (Koszyce) & - & $90 \%$ & - & - & V & $10 \%$ \\
\hline
\end{tabular}

Źródło: M. Ehnl, op. cit., s. 42, 44, 47; Schematismus für das k.u.k. Heer, s. 674, 704, 732.

W Twierdzy Przemyśl służyło osiem kompanii z trzech batalionów saperów: c. i k. 3 Batalionu Saperów (k.u.k. 3 SappB.), c. i k. 5 Batalionu Saperów (k.u.k. 5 SappB.), c. i k. 10 Batalionu Saperów (k.u.k. 10 SappB. ${ }^{132}$. Na ich strukturę narodowościową duży wpływ miało to, w której części konkretnego okręgu korpusu były one uzupełniane. W tym przypadku mamy do czynienia odpowiednio z okolicami Pettau (Ptuj) w północno-wschodniej Słowenii, Komárom (pogranicze słowacko-węgierskie) oraz z Przemyślem. Struktura językowa całych wymienionych tu batalionów saperów w czerwcu $1914 \mathrm{r}$. przedstawiała się następująco:

${ }^{128}$ Schematismus für das k.u.k. Heer, s. 742.

${ }^{129}$ M. Ehnl, op. cit., s. 47.

${ }^{130}$ Organische Bestimmungen für die k.k. Landwehr-(Landesschützen-) Ergänzungsbezirkskommandos, „Normalverodnungsblatt für das k.u.k. Heer”, 5. Stück vom 1 Februar 1913, Beilage 1, s. 9.

${ }^{131}$ M. Ehnl, op. cit., s. 81.

${ }^{132}$ W. Gorgosz, op. cit., tabl. II; B. Geőcze, op. cit., załącznik nr 1. 
Tabela 12. Struktura językowa k.u.k. 3, 5, 10 SappB.

\begin{tabular}{|l|c|c|c|c|c|c|c|}
\hline & $\begin{array}{c}\text { Uzupełniany } \\
\text { w obrębie } \\
\text { korpusu }\end{array}$ & $\begin{array}{c}\text { Język } \\
\text { niemiecki } \\
(\%)\end{array}$ & $\begin{array}{c}\text { Język } \\
\text { węgierski } \\
(\%)\end{array}$ & $\begin{array}{c}\text { Język } \\
\text { słoweński } \\
(\%)\end{array}$ & $\begin{array}{c}\text { Język } \\
\text { polski } \\
(\%)\end{array}$ & $\begin{array}{c}\text { Język } \\
\text { ukraiński } \\
(\%)\end{array}$ & $\begin{array}{c}\text { Inny } \\
\text { język } \\
(\%)\end{array}$ \\
\hline K.u.k. 3 SappB. & $\begin{array}{c}\text { III (Graz) } \\
\text { Pettau }\end{array}$ & 48 & - & 45 & - & - & 7 \\
\hline K.u.k. 5 SappB. & $\begin{array}{c}\text { V (Pozsony) } \\
\text { Komárom }\end{array}$ & 40 & 32 & 23 & - & - & 5 \\
\hline K.u.k. 10 SappB. & $\begin{array}{c}\text { X (Przemyśl) } \\
\text { Przemyśl }\end{array}$ & - & - & - & 50 & 30 & 20 \\
\hline
\end{tabular}

Źródło: M. Ehnl, op. cit., s. 66-67; Schematismus für das k.u.k. Heer, s. 940, 942, 947.

Brak informacji, które pozwalałyby wątpić, że dane dla k.u.k. 3 i 10 SappB. po mobilizacji w znaczący sposób różniły się od przedstawionych w Tabeli 10; możemy założyć, że zbliżone proporcje panowały w kompaniach tych batalionów służących w Przemyślu. W odniesieniu do danych dotyczących k.u.k. 5 SappB. należy zwrócić uwagę na pomyłkę, jaka najprawdopodobniej zaszła w przypadku 23\% żołnierzy mających posługiwać się językiem słoweńskim. Batalion ten był uzupełniany w zachodnich i północno-zachodnich Węgrzech, o czym świadczą dane z „List Strat”. Wymownym przykładem jest „Lista Strat" nr 133, gdzie znajdujemy nazwiska żołnierzy i oficerów 3 kompanii tego batalionu m.in. poległych dniach 20-22 grudnia 1914 r. Najprawdopodobniej są to straty poniesione przez kompanię w czasie walk o pozycję przedpolową „Na Górach” w tym czasie, o czym świadczy odnotowanie w tym spisie kpt. Hermila Kozmutzy, rannego w czasie tych walk w głowę ${ }^{133}$, ponadto ośmiu innych żołnierzy poległych w dniach 20-21 grudnia. Z 16 żołnierzy wyszczególnionych na tej liście wszyscy pochodzili z komitatów położonych w zachodnich, północno-zachodnich i północnych Węgrzech: po jednym z Bars, Győr, Heves, Komárom, Zala i Zemplén, po dwóch z Bereg, Máramaros i Szabolcs oraz czterech z Vas ${ }^{134}$, a więc terenów dziś znajdujących się w zachodnich Węgrzech, na Słowacji i na Ukrainie Zakarpackiej. Także dane z innych „List Strat" wskazują, że żołnierze służący w tej kompanii pochodzili w przeważającej większości z terenów znajdujących się w obrębie V Korpusu. Zatem wśród zaznaczonych dla 1914 r. 23\% w grę mogli wchodzić żołnierze posługujący się językiem nie słoweńskim, ale słowackim. Pozostałe 5\% mogli stanowić żołnierze posługujący się językiem ukraińskim i rumuńskim.

Niewiele wiadomo na temat składu narodowościowego oddziałów technicznych armii wspólnej służących w Przemyślu, przede wszystkim oddziałów Kolejki Polowej (Feldbahn) będącej częścią c. i k. Pułku Kolejowego (k.u.k.

\footnotetext{
${ }^{133}$ G. Nónay, op. cit., s. 138, 143.

${ }^{134}$ „Verlustliste”, nr 133 z 25 lutego 1915 r.
} 
Eisenbahnregiment). Pułk ten uzupełniano w obrębie wszystkich korpusów z wyjątkiem XIV (Innsbruck) i XVI (Ragusa/Dubrownik) ${ }^{135}$.

W opracowaniu Ehnla dane dotyczące struktury językowej c. i k. Pułku Kolejowego podane zostały łącznie z innymi jednostkami łączności, lotnictwa i transportu (Telegraphenregiment, Luftschifferabteilung, Automobilabteilung). Ogólnie ich struktura językowa latem 1914 r. przedstawiała się następująco: język niemiecki $-30 \%$, węgierski $25 \%$, czeski $20 \%$, inny język $25 \%{ }^{136}$.

W przypadku służących w Twierdzy Przemyśl oddziałów należących do c. i k. Pułku Kolejowego, wartościowego materiału w kwestii przynależności krajowej służących w nich żołnierzy przynosi „Lista Strat” nr $602^{137}$, na której ujęto żołnierzy tego pułku służących w Przemyślu (tak przynajmniej wynika z oznaczenia pododdziałów). Na liście tej znajduje się 449 nazwisk żołnierzy służących w tych jednostkach, przy czym w przypadku jednego nie oznaczono jego przynależności krajowej.

Na 448 żołnierzy 262 (58,5\%) pochodziło z Przedlitawii, 186 (41,5\%) z Węgier.

W przypadku Przedlitawii pochodzenie żołnierzy było następujące: Czechy 33, Dolna Austria - 17, Galicja - 196 (w tym z zachodniej 57, 139 ze wschodniej), Kraina - 1, Morawy - 8, Styria - 2, Śląsk - 5 .

W przypadku Węgier ustalone pochodzenie 180 żołnierzy przedstawiało się następująco: z komitatów, które w całości lub znaczącej części znajdują się w granicach dzisiejszej Słowacji, pochodziło $62^{138}$, Węgier - $77^{139}$, Rumunii - $32^{140}$, Serbii $-4^{141}$, Ukrainy $-5^{142}$.

Na podstawie tych danych jedyną pewną rzeczą, jaką możemy powiedzieć o składzie narodowościowym tej jednostki jest to, że uzupełniana na terenie całej monarchii w dużej mierze odzwierciedlała jej złożoną kompozycję etniczną, trudno jednak dokładnie określić, w jakich dokładnie proporcjach.

Trudno też dokładnie oszacować skład narodowościowy oddziałów roboczych, które należą do najsłabiej rozpoznanych i przedstawionych w literaturze

\footnotetext{
${ }^{135}$ Seidels, s. 103.

${ }^{136}$ M. Ehnl, op. cit., s. 70.

137 „Verlustliste”, nr 602, z 26 lipca 1917 r.

138 Árva - 1, Szepes - 1, Sáros - 1, Trencsén - 4, Zemplén - 3, Pozsony - 18, Nyitra - 20, Bars -7 , Hont -7 .

${ }^{139}$ Abauj-Torna - 1, Komárom - 9, Esztergom - 2 (mniej więcej połowa tych komitatów znalazła się po 1918 r. w granicach Czechosłowacji), Borsod - 1, Szabolcs - 1, Moson - 1 (po 1918 r. około połowy tego terenu przypadło Austrii), Sopron - 7, Győr - 1, Heves - 2, Hajdu - 2, Jász-Nagykun-Szolnok - 1, Pest-Pilis-Solt-Kiskun - 32 (w tym 5 z Budapesztu), Veszprém - 2, Fejér - 12, Békés 2 , Tolna -1 .

${ }^{140}$ Szatmár - 2, Szolnok-Doboka - 2, Bihar - 4, Kolozs - 3, Arad - 1, Torda-Aranyos - 2, Kis-Kükülő - 1, Nagy Kükülő - 2, Udvárhely - 1, Brassó - 3, Fogaras - 4, Szeben - 2, Hunyad - 1, Krassó-Szörény -2 , Temes -2 .

${ }^{141}$ Bács-Bodrog -3 , Torontál - 1 .

${ }^{142}$ Máramaros.
} 
przedmiotu formacji służących w Twierdzy Przemyśl ${ }^{143}$. Wedle różnych danych (podanych głównie przez autorów walczących w Twierdzy Przemyśl) w Przemyślu było od 67 lub 70 do 84 oddziałów roboczych (w tym ostatnim przypadku oddziałów węgierskich miało być więcej niż 60) i które w sumie liczyły od 20 000 do 29000 ludzi ${ }^{144}$. Ogólnie miały one w około 60\% (a nawet 75\% ${ }^{145}$ ) składać się z Węgrów ${ }^{146}$.

$\mathrm{Na}$ obecnym etapie badań trudno dokładnie określić, jaka była ich struktura i z jakich części monarchii pochodziły. Przynajmniej niektóre oddziały robocze tworzone były w oparciu o strukturę organizacyjną pułków armii wspólnej lub obrony krajowej. Na podstawie informacji prasowych z epoki udało się zidentyfikować oddziały robocze utworzone na bazie k.węg. 1, 13, 16, 29, 30 i 31 Pułku Piechoty Honwedu (k.u. 1, 13, 16, 29, 30, 31 LIR) oraz c. i k. 32, 48, 77 Pułku Piechoty (k.u.k. 32, 48, 77 IR) ${ }^{147}$. Wiadomo, że oddział roboczy utworzony na bazie k.u. 13 LIR liczył ok. 1200 żołnierzy ${ }^{148}$, utworzony na bazie k.u.k. 32 IR około $1500^{149}$, zaś oddział 29/I, utworzony przez komendę pospolitego ruszenia przy k.węg. 29 Piechoty Honwedu - 1500 żołnierzy. Według służącego w tym oddziale por. Jenő Fodora, każdy z 75 oddziałów roboczych służących w Przemyślu liczył 260 żołnierzy ${ }^{150}$.

${ }^{143}$ A. Watson, op. cit., przypis 14 do rozdz. II, s. 259.

${ }^{144}$ B. Geöcze, op. cit., s. 21; F. Conrad v. Hötzendorf, Aus meiner Dienstzeit 1906-1918, 5. Bd., załącznik D; J. Fodor, Przemyslből haza Szibérián át. I, Przemysl vedelmenek kiépitésé, „,Fogadó: országos vendéglős szakközlöny”, R. 14, nr 20 z 15 października 1917, s. 2; V. Nerad, Przemyśl: Erinnerungen des Genieoffiziers Ing. Viktor Nerad, Salzburg 2015, s. 14; O. Stolz, op. cit., s. 180; A. Watson, op. cit., s. 54.

${ }^{145}$ J. Ferenc, Przemyśl, „Magyarság”, R. 10, nr 100 z 4 maja 1929, dodatek, s. III.

${ }^{146}$ B. Geöcze, op. cit., s. 25.

${ }^{147} \mathrm{O}$ oddziale roboczym utworzonym na bazie c. i k. 32 IR, zob. Budapest volt házi ezredének a cs. és kir. 32. gyalogezrednek története (1741-1918), szerk. S. Tinódi Varga, [Budapest 1930], s. 270. W oddziale roboczym utworzonym na bazie k.węg. 16 Pułku Piechoty Honwedu służył anonimowy oficer, którego dziennik został opublikowany przez Istvána Lagzi w miesięczniku „Napjaink” w 1990 r., zob. Lagzi I., ,....Mindnyájunknak ei kell menni...”: a második przemysli magyar napló, 1914, I. rész, „Napjaink”, 1990, R. 29, nr 1, s. 21-30; II. rész, „Napjaink”, 1990, R. 29, nr 2, s. 31-39. Inne węgierskie oddziały robocze, ustalone głównie na podstawie doniesień prasy węgierskiej z okresu walk o Twierdzę Przemyśl (w przypadku c. i k. 48 IR zob. „Zala”, R. 42, nr 74 z 3 kwietnia 1915 r., s. 3-5). Wiele nazwisk żołnierzy służących w oddziałach roboczych (przede wszystkim węgierskich z oddziałów oznaczonych jako ArbAbt. I/1, 29, 30 i 31) zawiera wykaz jeńców z Przemyśla In Przemyśl Kriegsgefangene zusammengestelt nach den vom russischen Roten Kreuze eingelangten Gefangenen Listen. P4, 23 lutego 1916. Tam też kilkanaście nazwisk z oddziału roboczego oznaczonego 77. ArbAbt. (W sumie na wszystkich czterech listach jeńców z Przemyśla znajduje się nie więcej niż 14000 nazwisk, a zatem niewiele ponad 10\% wszystkich jeńców z twierdzy, zatem kilkanaście nazwisk z oddziału 77. ArbAbt. sygnalizuje jedynie obecność żołnierzy tej jednostki w Przemyślu, nie pozwala jednak wyciągać wniosków o jej liczebności). W. Gorgosz podał, że w Twierdzy Przemyśl służyło 13 wojskowych oddziałów roboczych, zob. W. Gorgosz, op. cit., tabl. II.

148 „Pressburger Zeitung”, R. 152, nr 53 z 23 lutego 1915 r., s. 3.

149 Budapest volt házi ezredének, s. 270.

${ }^{150}$ J. Fodor, op. cit., s. 2. 
W Kriegsgliederung der Besatzung... w części „Oddziały Robocze” ujęto następujące jednostki:

Lst. Art. Abt.: k.k. 1-7, 23, 24/2, 1-12/2, 1, 9/10, 11, 12, 13/11, 1-6/14 oraz k. u. 5-7, 11-15/IV. (te, jako oddziały artylerii pospolitego ruszenia, omówiono wyżej);

k.u.k. Mil.Arb.Abt. Nr. 1, 2/12;1-3/25; 1/26; 1-6/32; 1/48; 1-3/77;

k.u. Befestigungs-Arb.Abt. Nr. 1-5/Lst. 1; 1-14/Lst. 13, 15-17/Lst. 13; 1-6/Lst. 16; 1-12/Lst. 29; 1-6/Lst. 30; 1-4/Lst. 31;

k.u.k. Fst.Art.Arb.Abt. Nr. 13, 14, 15.

W sumie mamy tu do czynienia przynajmniej z 99 jednostkami - a zatem liczba zdecydowanie przewyższająca nawet najwyższą (84) liczbę oddziałów roboczych służących w Przemyślu. Odliczywszy oddziały zaliczone do jednostek artylerii pospolitego ruszenia zostaje 56 jednostek oznaczonych jako k.u.k. Mil.Arb.Abt. i k.u. Befestigungs-Arb.Abt. - a zatem mniej, niż najniższa wcześniej podawana liczba (67) oddziałów roboczych służących w Twierdzy Przemyśl. Nawet dodanie trzech oddziałów, oznaczonych jako k.u.k. Fst.Art. Arb.Abt., do tej wartości się nie zbliża. Wątpliwości budzi też, czy rzeczywiście aż 17 kompanii roboczych było utworzonych na bazie k.węg. 13 Pułku Piechoty Honwedu; przy założeniu, że każda z nich liczyła ok. 260 żołnierzy, dawałoby to ponad 4400 żołnierzy.

W sumie więc nadal w tym zakresie pozostaje wiele niewiadomych. Tym niemniej, na podstawie posiadanych informacji, można przynajmniej ustalić, na jakich terenach poszczególne oddziały oznaczone jako k.u.k. Mil.Arb.Abt. i k.u. Befestigungs-Arb.Abt., były mobilizowane i jaki w przybliżeniu był ich skład narodowościowy, co zaprezentowano w poniższej tabeli. Wątpliwości co do oddziałów k.u.k. Fst. Art. Arb. Abt. Nr. 13, 14, 15, sprawiły, że pominięto je w poniższym zestawieniu.

Tabela 13. Struktura językowa okręgów uzupełnień armii wspólnej i Honwedu w których tworzono zidentyfikowane oddziały robocze slużące w Twierdzy Przemyśl.

\begin{tabular}{|c|c|c|c|}
\hline Oddział roboczy & $\begin{array}{l}\text { Okręg mobilizacyjny } \\
\text { pułku piechoty } \\
\text { Honwedu (k.u. LIR) lub } \\
\text { armii wspólnej (c. i k.). }\end{array}$ & $\begin{array}{c}\text { Struktura językowa } \\
\text { okregu } \\
\text { mobilizacyjnego } \\
\text { wg danych ze spisu } \\
\text { z } 1910 \mathrm{r} \text {. }\end{array}$ & $\begin{array}{l}\text { Struktura } \\
\text { językowa } \\
\text { oddziałów } \\
\text { w } 1914 \text { r. }\end{array}$ \\
\hline k.u.k. Mil.Arb.Abt. & K.u.k. 12 IR & $53,1 \%$ - węgierski & $58 \%$ - węgierski \\
\hline \multirow[t]{3}{*}{ Nr. $1,2 / 12$} & Komitat Komárom, & $38,9 \%$ - słowacki & $31 \%$ - słowacki \\
\hline & Galgocz, Tapolcsány, & $6,9 \%$ - niemiecki & $11 \%$ - inny \\
\hline & $\begin{array}{l}\text { Vágsellye, Zsambokrét, } \\
\text { miasto Nyitra komitatu } \\
\text { Nyitra }\end{array}$ & $1,1 \%$ - inny & \\
\hline
\end{tabular}




\begin{tabular}{|c|c|c|c|}
\hline $\begin{array}{l}\text { k.u.k. Mil.Arb.Abt. } \\
\text { Nr. } 1-3 / 25\end{array}$ & $\begin{array}{l}\text { K.u.k. } 25 \text { IR } \\
\text { Komitaty Gömör és } \\
\text { Kis-Hont, Zólyom, } \\
\text { powiaty Balassa- } \\
\text { Gyarmat, Szécsény, } \\
\text { Losoncz (z miastem) } \\
\text { i Fülek komitatu } \\
\text { Nógrád }\end{array}$ & $\begin{array}{l}53,2 \% \text { - węgierski } \\
44,1 \% \text { - słowacki } \\
1,3 \% \text { - niemiecki } \\
1,4 \% \text { - inny }\end{array}$ & $\begin{array}{c}56 \% \text { - węgierski } \\
41 \% \text { - słowacki } \\
3 \% \text { - inny }\end{array}$ \\
\hline $\begin{array}{l}\text { k.u.k. Mil.Arb.Abt. } \\
\text { Nr. } 1,2 / 26\end{array}$ & $\begin{array}{l}\text { K.u.k. } 26 \text { IR } \\
\text { Komitaty Bars, } \\
\text { Esztergom, Hont }\end{array}$ & $\begin{array}{l}52,2 \% \text { - węgierski, } \\
38,7 \% \text { - słowacki } \\
8,3 \% \text { - niemiecki } \\
0,8 \% \text { - inny }\end{array}$ & $\begin{array}{c}53 \% \text { - węgierski } \\
\begin{array}{c}38 \% \text { - słoweń- } \\
\text { ski }^{151}\end{array} \\
9 \% \text { - inny }\end{array}$ \\
\hline $\begin{array}{l}\text { k.u.k. Mil.Arb.Abt. } \\
\text { Nr. } 1-3 / 32\end{array}$ & $\begin{array}{l}\text { K.u.k. } 32 \text { IR } \\
\text { Powiaty Pest górny, } \\
\text { Pest centralny, Pest } \\
\text { dolny, Pilis górny, Pilis } \\
\text { dolny, Vác górny, Vác } \\
\text { dolny, miasto Vác, } \\
\text { miasto Szentendre } \\
\text { komitatu Pest-Pilis- } \\
\text { Solt-Kiskun }{ }^{152}\end{array}$ & $\begin{array}{l}86,1 \% \text { - węgierski, } \\
8,4 \% \text { - niemiecki, } \\
2,6 \% \text { - słowacki } \\
2,9 \% \text { - inny }\end{array}$ & $\begin{array}{l}91 \% \text { - węgierski } \\
9 \% \text { - inny }\end{array}$ \\
\hline $\begin{array}{l}\text { k.u.k. Mil.Arb.Abt. } \\
\text { Nr. } 1 / 48\end{array}$ & $\begin{array}{l}\text { K.u.k. } 48 \text { IR } \\
\text { Komitat Zala, powiaty } \\
\text { Szentgotthárd } \\
\text { i Muraszombat komitatu } \\
\text { Vas }\end{array}$ & $\begin{array}{l}64,6 \%-\text { węgierski } \\
16,1 \% \text { - chorwacki } \\
6,2 \%-\text { niemiecki } \\
13,1 \%-\text { inny }^{153}\end{array}$ & $\begin{array}{l}82 \% \text { - węgierski } \\
18 \% \text { - inny }\end{array}$ \\
\hline $\begin{array}{l}\text { k.u.k. Mil.Arb.Abt. } \\
\text { Nr. } 1-3 / 77\end{array}$ & $\begin{array}{l}\text { K.u.k. } 77 \text { IR } \\
\text { Powiaty Drohobycz, } \\
\text { Sambor, Stary Sambor, } \\
\text { Turka }\end{array}$ & $\begin{array}{l}63,6 \% \text { - ukraiński } \\
35,2 \% \text { - polski } \\
1,2 \% \text { - inny }\end{array}$ & $\begin{array}{l}69 \% \text { - ukraiński, } \\
31 \% \text { - Inny }\end{array}$ \\
\hline
\end{tabular}

${ }^{151}$ Raczej błąd i chodzi o język słowacki - okręg mobilizacyjny k.u.k. 26 IR rozciągał się od okolic Esztergom w kierunku północnym, obejmując okolice Ipolyság/Šahy, Aranyosmárot/Zlaté Moravce, Selmecz- és Bélabánya/Banská Štiavnica a Belá w granicach dzisiejszej Słowacji.

${ }^{152} \mathrm{Wg}$ map zamieszczanych w Szematyzmach armii austro-węgierskiej publikowanych po $1883 \mathrm{r}$. okręg mobilizacyjny c. i k. 32 IR pokrywał się z okręgiem mobilizacyjnym k.u. 1 LIR i obejmował: Budapeszt oraz powiaty Alsódabas, Aszód, Bia, Gödölö, Monor, Pomáz, Ráckeve, Vác (z miastem) komitatu Pest-Pilis-Solt-Kiskun.

${ }^{153}$ W kategorii „inny język” mieścili się przede wszystkim słowiańscy Wendowie mieszkający w dużej liczbie w powiecie Muraszombat, zob. A Magyar Szent Korona, s. 58. 


\begin{tabular}{|c|c|c|c|}
\hline $\begin{array}{l}\text { k.u. Befestigungs- } \\
\text { Arb.Abt. } \\
\text { Nr. 1-5/Lst. } 1\end{array}$ & $\begin{array}{l}\text { K.u. } 1 \text { LIR } \\
\text { Budapeszt oraz powiaty } \\
\text { Alsódabas, Aszód, Bia, } \\
\text { Gödölö, Monor, Pomáz, } \\
\text { Ráckeve, Vác } \\
\text { (z miastem) komitatu } \\
\text { Pest-Pilis-Solt-Kiskun }\end{array}$ & $\begin{array}{l}83,8 \% \text { - węgierski } \\
10,5 \% \text { - niemiecki } \\
3,2 \% \text { - słowacki } \\
\text { 2,3\% - inne języki }\end{array}$ & $\begin{array}{l}\text { 91\% - węgierski, } \\
\text { 9\% - inny język }\end{array}$ \\
\hline $\begin{array}{l}\text { k.u. Befestigungs- } \\
\text { Arb.Abt. } \\
\text { 1-14/Lst. 13, 15-17/ } \\
\text { Lst. } 13\end{array}$ & $\begin{array}{l}\text { K.u. } 13 \text { LIR } \\
\text { Komitaty Pozsony } \\
\text { i Moson oraz powiaty } \\
\text { Kapuvár, Kismárton } \\
\text { i Csorna oraz miasto } \\
\text { Ruszt komitatu Sopron, } \\
\text { powiat Postyen } \\
\text { komitatu Nyitra }\end{array}$ & $\begin{array}{l}45,5 \% \text { - węgierski } \\
28,9 \% \text { - słowacki } \\
21,1 \% \text { - niemiecki } \\
3,3 \% \text { - chorwacki } \\
1,2 \% \text { - inny }\end{array}$ & $\begin{array}{l}51 \% \text { - słowacki } \\
28 \% \text { - węgierski } \\
20 \% \text { - niemiecki } \\
1 \% \text { - inny }\end{array}$ \\
\hline $\begin{array}{l}\text { k.u. Befestigungs- } \\
\text { Arb.Abt. } \\
\text { 1-6/Lst. } 16\end{array}$ & $\begin{array}{l}\text { K.u. 16 LIR } \\
\text { (Beszterczebánya) } \\
\text { Komitaty Gömör és } \\
\text { Kis-Hont, Zólyom }\end{array}$ & $\begin{array}{l}55,6 \% \text { - węgierski } \\
41,8 \% \text { - słowacki } \\
1,4 \% \text { - niemiecki } \\
1,2 \% \text { - inny }\end{array}$ & $\begin{array}{l}56 \%-\text { węgierski } \\
41 \% \text { - słowacki } \\
3 \% \text { - inny }\end{array}$ \\
\hline $\begin{array}{l}\text { k.u. Befestigungs- } \\
\text { Arb.Abt. } \\
\text { 1-12/Lst. } 29\end{array}$ & $\begin{array}{l}\text { K.u. } 29 \text { LIR } \\
\text { Komitat Jász-Nagykun- } \\
\text { Szolnok oraz powiaty } \\
\text { Abony, Dunavecse, } \\
\text { Kúnszentmiklós, } \\
\text { Nagykáta miasta } \\
\text { Kecskemét, Nagykörös, } \\
\text { Czegléd, komitatu Pest- } \\
\text { Pilis-Solt-Kiskun }\end{array}$ & $\begin{array}{l}98,2 \% \text { - węgierski } \\
1,8 \% \text { - inne }\end{array}$ & $\begin{array}{l}91 \% \text { - węgierski } \\
9 \% \text { - inny }\end{array}$ \\
\hline $\begin{array}{l}\text { k.u. Befestigungs- } \\
\text { Arb.Abt. } \\
\text { 1-6/Lst. } 30\end{array}$ & $\begin{array}{l}\text { K.u. } 30 \text { LIR } \\
\text { Powiaty Apatin, } \\
\text { Bácsalmás, Baja } \\
\text { (z miastem), Zombor } \\
\text { (z miastem) komitatu } \\
\text { Bács-Bodrog, } \\
\text { powiaty: Kalocsa, } \\
\text { Kiskunhalas, Kiskőrös, } \\
\text { Kiskunfélegyháza } \\
\text { komitatu Pest-Pilis- } \\
\text { Solt-Kiskun }\end{array}$ & $\begin{array}{l}\text { 68,2\% - węgierski } \\
19 \% \text { - niemiecki } \\
5 \% \text { - serbski } \\
7,8 \% \text { - inny }\end{array}$ & $\begin{array}{l}91 \% \text { - węgierski } \\
9 \% \text { - inny }\end{array}$ \\
\hline
\end{tabular}




\begin{tabular}{|l|l|l|l|}
\hline $\begin{array}{l}\text { k.u. Befestigungs- } \\
\text { Arb.Abt. }\end{array}$ & K.u. 31 LIR & $86,7 \%$-węgierski, & $92 \%$ - węgierski \\
1-4/Lst. 31. & $\begin{array}{l}\text { Komitaty Györ, } \\
\text { Komárom, powiaty } \\
\text { Enyig, Veszprém i Zircz } \\
\text { komitatu Veszprém, } \\
\text { powiat Érsékujvár } \\
\text { komitatu Nyitra }\end{array}$ & $6,4 \%$ - niemiecki & $8 \%$ - inny \\
\hline
\end{tabular}

Źródło: A Magyar Szent Korona, s. 20-21, 24-27, 46-47, 70-71, 76-77, 96-97, 106-109, 116-117, 128-129, 144-145, 154-155, 176-177, 182-183, 190-191, 198-199, 232-233; Schematismus für das k.u.k. Heer, s. 402, 428, 430, 442, 474, 532; A magyar királyi Honvédség elhelyezési térképe, [1910?]; S. Kasznica i in., op. cit., s. 21-23; M. Ehnl, op. cit., s. 19, 22, 23, 25, 30, 84, 86, 89; Heeres- (Marine-) Ergänzungs-Bezirks-Eintheilung, „Verordnungsblatt für das k.k. Heer. Normal-Verordnungen”, 49. Stück vom 21. Dezember 1882, s. 7, 9, 10-11, 12.

W przypadku oddziałów roboczych należy pamiętać, że były one mniej liczebne niż odpowiednie pułki piechoty, dlatego ich skład nie musiał być wiernym odzwierciedleniem struktury narodowościowej całego pułku, ale dużo zależało też od tego, z jakiego rejonu okręgu mobilizacyjnego pochodziły.

Jak wynika z powyższej tabeli, w oddziałach roboczych utworzonych na bazie k.u. 1, 16, 29, 30, 31 LIR oraz k.u.k. 12, 25, 26, 32 i 48 IR przeważać mogli (w różnym stopniu) żołnierze narodowości węgierskiej, w przypadku k.u.k. 77 IR - ukraińskiej. W odniesieniu do oddziału utworzonego na bazie k.u. 30 LIR wiadomo, że w Twierdzy Przemyśl w momencie jej poddania znajdowało się około 300 robotników z okolic Kiskunhalas ${ }^{154}$. Samo miasto, leżące w na południu w przeważającej części węgierskojęzycznego (ponad 87\%) komitatu Pest-Pilis-Solt-Kiskun w 1910 r. liczyło ponad 24000 mieszkańców, z czego ponad 99\% stanowili Węgrzy ${ }^{155}$. Te proporcje musiały być odzwierciedlone także w tym oddziale roboczym.

Oddział roboczy, utworzony w okręgu uzupełnień k.u. 13 LIR, pochodził $\mathrm{z}$ terenów w dużej mierze o mieszanym, słowacko-niemiecko-węgierskim, charakterze narodowościowym. $Z$ pewnością służyło w nim wielu mieszkańców Bratysławy, w tym wielu Niemców ${ }^{156}$. W samej Bratysławie Niemcy stanowili największą grupę narodowościową (niespełna 42\%), Węgrzy 40,5\%, Słowacy niecałe $15 \%$. Jednakże biorąc pod uwagę miasto wraz z otaczającym ją powiatem, Węgrzy stanowili tu $43 \%$, Słowacy niespełna $41 \%$, Niemcy zaś $14,2 \%{ }^{157}$. W prasie komitatu Moson („Dunatúli Napló”), który znajdował się w obszarze mobilizacyjnym tego pułku, znajdujemy informacje o przynajmniej kilkudziesięciu żołnierzach, którzy pochodzili z tego komitatu (konkretnie z miejscowości

\footnotetext{
${ }^{154}$ „Kiskun-Halas Helyi Értesítője”, R. 16, nr 29 z 19 lipca 1916, s. 3.

${ }^{155}$ A Magyar Szent Korona, s. 198-199.

156 „Pressburger Zeitung”, R. 152, nr 80, z 21 marca 1915 r., s. 5.

${ }^{157}$ A Magyar Szent Korona, s. 154-155.
} 
Dunakiliti, Feketeerdő, Moson i Rajka) i którzy służyli w oddziałach roboczych w Twierdzy Przemyśl $1^{158}$. Według danych ze spisu z 1910 r. większość mieszkańców komitatu Moson posługiwała się językiem niemieckim (55\%), węgierskim niespełna $35 \%$, zaś $8,6 \%$ chorwackim ${ }^{159}$. Wiele wskazuje więc na to, że w oddziale roboczym utworzonym w okręgu uzupełnień k.u. 13 LIR znaczący był udział żołnierzy narodowości słowackiej i niemieckiej, zapewne liczebnie dominujący nad Węgrami.

Roboczy charakter miał oddział, którego żołnierze od 29 sierpnia 1914 r. kwaterowali przy ul. Smolki. Prawdopodobnie był to k.k. LstLastenträgerAbt. Nr. 1/3 (jak można wnioskować z nazwy, był to oddział transportowy), w którym służył znany z dziennika Heleny Jabłońskiej Włoch z Triestu ${ }^{160}$ (podporucznik, później porucznik) Angelo Casagrande ${ }^{161}$. Z dziennika Jabłońskiej wynika też, że oddział tej tworzyli przede wszystkim Włosi. Trudno jest oszacować wielkość tego oddziału. Był on jednakże na tyle duży, że ppor. Casagrande był w stanie oddać do dyspozycji Jabłońskiej grupę 90 żołnierzy do sprzątania kamienicy znajdującej się pod jej opieką, a zdewastowanej przez kwaterujących w niej żołnierzy ${ }^{162}$.

W odniesieniu do oddziałów technicznych należy też odnotować obecność w Przemyślu szeregu innych formacji pomocniczych, nie zawsze nawet stricte związanych z wojskiem - chociażby taborów czy straży pożarnej.

Co prawda wszystkie jednostki wojskowe dysponowały własnymi taborami, ale były one niewystarczające. Przewidując wybuch wojny zakładano, że tabory będą składać się w przeważającej części z cywilnych woźniców pochodzących $\mathrm{z}$ rejonów koncentracji armii ${ }^{163}$.

K.u. 23 LITD od momentu przybycia do Galicji w końcu sierpnia 1914 r. korzystała z miejscowych cywilnych podwód ${ }^{164}$. Naturalną rzeczą było też to, że na potrzeby twierdzy rekwirowano wozy i woźniców z najbliższych terenów, a więc w przypadku Twierdzy Przemyśl terenów zamieszkanych przez ludność ukraińską i polską. Ludzie ci wraz ze swymi zaprzęgami także zostali zamknięci w oblężonej twierdzy. Nie jest znana ich dokładna liczba, ale możemy mówić nawet o kilku tysiącach ludzi. D. Nónay wspominał, że pod koniec listopada do znajdującego się pod jego komendą V Obwodu Obronnego kwatermistrzostwo k.u. 23 LITD zamierzało przysłać kolumnę transportową liczącą 1200 wozów w celu wywiezienia znajdujących się na podległym mu terenie zapasów siana ${ }^{165}$.

\footnotetext{
158 „Dunatúli Napló”, R. 23, nr 72 z 30 marca 1915 r., s. 2; nr 74 z 1 kwietnia 1915 r., s. 2.

${ }^{159}$ A Magyar Szent Korona, s. 26-27.

${ }^{160}$ J. Jabłońska, Dziennik z oblężonego Przemyśla 1914-1915, Przemyśl 2017, s. 78-79.

161 „Badener Zeitung”, R. 36, nr 18 z 3 marca 1915 r., s. 2; „Grazer Volksblatt”, R. 48, nr 299 z 3 maja 1915 r., s. 3; „Verlustliste”, nr 299 z 5 sierpnia 1915 r., s. 4.

162 J. Jabłońska, op. cit., s. 80.

${ }^{163}$ A. Kraus, Die Ursachen unserer Niederlage: Erinnerungen und Urteile aus dem Weltkrieg, München 1921, s. 105.

${ }^{164}$ MNZP. ApEM, Teka 3, sygn. MP-Hist. 390, k. 2.

${ }^{165}$ D. Nónay, op. cit., s. 96.
} 
Proporcjonalna ilość zaprzęgów musiała być przeznaczona do obsługi potrzeb logistycznych k.k. 85 LIBrig oraz brygad pospolitego ruszenia. Liczba ta może wydawać się zawyżoną, musimy jednak pamiętać, że właściwie cały transport w twierdzy opierał się na sile zwierząt pociągowych i znaczna część z około 21000 koni, jakie znajdowały się w twierdzy na początku II oblężenia, stanowiła własność cywilnych woźniców.

W przypadku straży pożarnej kilka informacji przynosi „Pamiętnik” mieszkającego w chwili wybuchu wojny w Błażowej Kazimierza Krygowskiego. Krygowski, urodzony w 1878 r., w momencie wybuchu wojny miał 36 lat i podlegał służbie w pospolitym ruszeniu. Nie został wcielony do miejscowego pułku pospolitego ruszenia (k.k. 17 LstIR), ale w Przemyślu znalazł się bez konkretnego przydziału wraz z dziesiątkami (czy nawet setkami) innych rezerwistów, którzy także nie przynależąc do określonej jednostki odbyli wraz z nim podróż koleją między Rzeszowem a Przemyślem. Na miejscu strażacy, którzy znajdowali się wśród przybyłych, skupili się razem - w grupie tej, wedle słów Krygowskiego znaleźli się członkowie ochotniczych straży pożarnych z całej środkowej Galicji, począwszy od Dębicy po Gródek Jagielloński. Przez kilka tygodni Komenda Twierdzy nie bardzo wiedziała co z tymi ludźmi zrobić, w końcu przydzielono ich do przemyskiej zawodowej straży pożarnej, w której Krygowski służył do upadku twierdzy ${ }^{166}$.

Na zakończenie należy poruszyć jeszcze jedną kwestię - odsetka żołnierzy żydowskich (wyznania mojżeszowego) w garnizonie Twierdzy Przemyśl.

Według danych ze spisów z 1910 r. Żydzi stanowili 4,6\% ludności Przedlitawii (w samej Galicji stanowili oni 10,86\% mieszkańców) i 4,5\% ludności Zalitawii 167 . W skali całego państwa odsetek ludności żydowskiej wynosił niespełna 4,6\%. Ponieważ Żydzi nie byli traktowani w Austro-Węgrzech jako osobna narodowość, dlatego nie ma danych co ich udziału procentowego w poszczególnych oddziałach, jednak szacuje się, że w armii austro-węgierskiej służyło (w ciągu całej wojny) w sumie ok. 300000 Żydów, co stanowiło 4\% żołnierzy. Żydzi reprezentowani byli we wszystkich rodzajach sił zbrojnych, ale największa ich liczba służyła w piechocie. O ile wśród oficerów zawodowych stanowili oni $3 \%$, to wśród oficerów rezerwy $17 \%{ }^{168}$.

Założyć można, że te dane znalazły swoje odzwierciedlenie w strukturze narodowościowej (czy raczej wyznaniowej) załogi Twierdzy Przemyśl, szczególnie w jednostkach galicyjskich.

${ }^{166}$ K. Krygowski, Pamiętnik, Poznań 2016, s. 208-221.

${ }^{167}$ W. Bihl, Die Juden, w: Die Habsburgermonarchie 1848-1918, 3. Bd., Die Völker des Reiches, 2. Tb., hrsg. von A. Wandruszka, P. Urbanitsch, Wien 1980, tab. 88 i 89, s. 882-883.

${ }^{168}$ M. Rauchensteiner, The First World War and the end of Habsburg Monarchy: 1914-1918, Wien-Köln-Weimar 2014, s. 342; Á. Biró i in., Węgierskie Lwy Judy w Galicji: katalog wystawy, Kraków 2017, s. 38. 
Tabela 14. Struktura wyznaniowa okręgów uzupełnień k.k. 17, 18, 19, 33, 34 i 35 LIR.

\begin{tabular}{|c|c|}
\hline $\begin{array}{c}\text { Okręg mobilizacyjny pułku piechoty austriackiej } \\
\text { Obrony Krajowej (k.k. LIR) oraz austriackiego } \\
\text { pospolitego ruszenia (k.k. LstIR) }\end{array}$ & $\begin{array}{c}\text { Struktura wyznaniowa } \\
\text { okręgu mobilizacyjnego } \\
\text { wg danych ze spisu z } 1910 \mathrm{r} \text {. }\end{array}$ \\
\hline K.k. 17 LIR (Rzeszów) & rzymsko-katolickie - 89,2\% \\
\hline $\begin{array}{l}\text { Galicja, powiaty: Kolbuszowa, Mielec, Ropczyce, } \\
\text { Rzeszów, Strzyżów, Tarnobrzeg }\end{array}$ & $\begin{array}{l}\text { mojżeszowe }-9,2 \% \\
\text { grecko-katolickie }-1,3 \% \\
\text { inne }-0,3 \%\end{array}$ \\
\hline K.k. 18 LIR (Przemyśl) & grecko-katolickie $-45,5 \%$ \\
\hline $\begin{array}{l}\text { Galicja, powiaty: Brzozów, Dobromil, Krosno, Lisko, } \\
\text { Przemyśl, Sanok }\end{array}$ & $\begin{array}{l}\text { rzymsko-katolickie }-43 \% \\
\text { mojżeszowe }-11 \% \\
\text { inne }-0,5 \%\end{array}$ \\
\hline K.k. 19 LIR (Lwów) & grecko-katolickie - 54,8\% \\
\hline $\begin{array}{l}\text { Galicja, powiaty: Bóbrka, Brzeżany, Lwów, Podhajce, } \\
\text { Przemyślany, Rohatyn, Sokal, Żółkiew }\end{array}$ & $\begin{array}{l}\text { rzymsko-katolickie }-30,6 \% \\
\text { mojżeszowe }-13,8 \% \\
\text { inne }-0,8 \%\end{array}$ \\
\hline $\begin{array}{l}\text { K.k. } 33 \text { LIR (Stryj) } \\
\text { Galicja, powiaty: Dolina, Drohobycz, Kałusz, } \\
\text { Sambor, Skole, Stary Sambor, Stryj, Turka, Żydaczów }\end{array}$ & $\begin{array}{l}\text { grecko-katolickie }-70,3 \% \\
\text { rzymsko-katolickie }-16,5 \% \\
\text { mojżeszowe - } 12 \% \\
\text { inne }-1,2 \%\end{array}$ \\
\hline $\begin{array}{l}\text { K.k. } 34 \text { LIR (Jarosław) } \\
\text { Galicja, powiaty: Cieszanów, Gródek Jagielloński, } \\
\text { Jarosław, Jaworów, Łańcut, Mościska, Nisko, } \\
\text { Przeworsk, Rawa Ruska, Rudki }\end{array}$ & $\begin{array}{l}\text { rzymsko-katolickie }-45,5 \% \\
\text { grecko-katolickie }-44,4 \% \\
\text { mojżeszowe - 9,6\% } \\
\text { inne }-0,5 \%\end{array}$ \\
\hline $\begin{array}{l}\text { K.k. } 35 \text { LIR (Złoczów) } \\
\text { Galicja, powiaty: Brody, Kamionka Strumiłowa, } \\
\text { Radziechów }{ }^{169}, \text { Skałat, Tarnopol, Trembowla, Zbaraż, } \\
\text { Zborów, Złoczów }\end{array}$ & $\begin{array}{l}\text { grecko-katolickie }-58,7 \% \\
\text { rzymsko-katolickie }-28,6 \% \\
\text { mojżeszowe - } 12,3 \% \\
\text { inne }-0,5 \%\end{array}$ \\
\hline
\end{tabular}

Źródło: S. Kasznica i in., op. cit., s. 6, 8-15; Schematismus der k.k. Landwehr...1913, mapa; M. Ehnl, op. cit., s. 75, 76, 77, 79; Organische Bestimmungen für die k.k. Landsturmbezirkskommandos, s. 6, 9-11.

${ }^{169}$ Wymieniony jako powiat w Organische Bestimmungen für die k.k. Landsturmbezirkskommandos. W istocie Radziechów leżał w powiecie kamioneckim. 
Jak wynika z tabeli, w pułkach mobilizowanych na terenie środkowej i wschodniej Galicji odsetek żołnierzy wyznania mojżeszowego mógł oscylować wokół $10 \%$. Należy zaznaczyć, że mógł być on nieco niższy - ludności żydowskiej powszechnie przypisywano tendencję do unikania wcielania jej do wojska ${ }^{170}$. W przypadku Rzeszowa (a zatem terenu uzupełniania k.k. 17 LstIR) taką postawę odnotował w swych pamiętnikach rzeszowski adwokat Wincenty Daniec, wedle którego w samym Rzeszowie na komisji wojskowej 1800 Żydów przedłożyło zaświadczenia lekarskie stwierdzające ich niezdolność do służby wojskowej ${ }^{171}$.

Brak danych, by te informacje zweryfikować w odniesieniu do wszystkich pułków. W przypadku Dańca, niekryjącego swych antysemickich poglądów, można mieć podejrzenie, że nie był obiektywny i pewne zjawiska przejaskrawiał. Podobne, choć oględniej wyrażone refleksje o niechęci Żydów do służby wojskowej, znajdujemy też w dzienniku mieszkającego w Munkács ${ }^{172}$, a zatem w okręgu mobilizacyjnym k.u. 11 LstIR, Tivadara Lehoczkyego ${ }^{173}$. Wskazuje to na pewną regułę postępowania wśród ludności żydowskiej sprawiającą, że odsetek żołnierzy i oficerów wyznania mojżeszowego w Twierdzy Przemyśl mógł być nieco niższy niż proporcjonalny udział Żydów w ogólnej liczbie ludności monarchii. Zapewne wysoki był udział Żydów wśród oficerów - w Przemyślu służyły głównie jednostki pospolitego ruszenia, ze znacznym udziałem oficerów rezerwy, wśród których, jak już wspomniano, Żydzi stanowili znaczący odsetek.

Podsumowując można stwierdzić, że z powodu niekompletności danych, w chwili obecnej nie sposób przedstawić dokładnej struktury narodowościowej załogi Twierdzy Przemyśl w okresie od września 1914 r. do marca 1915 r., można jednak wysnuć pewne ogólne wnioski.

W świetle przedstawionych $\mathrm{w}$ artykule danych większość załogi twierdzy stanowili żołnierze pochodzący z Zalitawii. Biorąc pod uwagę najliczniejsze jednostki, to $\mathrm{z}$ Węgier pochodziło 36 (w drugim oblężeniu 35) batalionów piechoty oraz większość oddziałów roboczych. Z Przedlitawii pochodziło 291/2 w pierwszym i $33 \frac{1}{2}$ batalionu w drugim oblężeniu oraz mniejsza od zalitawskiej liczba oddziałów roboczych.

Biorąc pod uwagę geograficzne pochodzenie jednostek węgierskich, to w świetle powyżej zaprezentowanych danych najliczniej reprezentowane były południowe, centralne, zachodnie i północne Węgry. Na obszarach tych Węgrzy niewątpliwie stanowili większość, jednak znaczący odsetek stanowiła też ludność słowacko-, niemiecko-, serbsko- i rumuńskojęzyczna. Zwraca uwagę fakt, że w Przemyślu brakowało jednostek z Chorwacji oraz z Siedmiogrodu (jedynie k.u. 16 MarschIR zaliczano do jednostek siedmiogrodzkich ${ }^{174}$ ). Było to o tyle istotne, że Chorwacja

\footnotetext{
${ }^{170}$ M. Rauchensteiner, op. cit., s 342.

${ }^{171}$ W. Daniec, Pamiętnik z przeżyć wielkiej wojny [Cz.1], Rzeszów 1925, s. 70.

${ }_{172}$ Obecnie Mukaczewo na Ukrainie Zakarpackiej.

${ }^{173}$ T. Lehoczky, Világháborúnk, I-II. rész, Beregszász-Ungvár 2016, s. 113, 189.

${ }^{174}$ Erdélyi ezredek a világháborúban, szerk. L. Dezseö, Budapest [1941], s. 84.
} 
praktycznie w $100 \%$ była chorwackojęzyczna, zaś w Siedmiogród zamieszkany był przez najliczniejszą mniejszość narodową ówczesnych Węgier - Rumunów; ponadto znaczący odsetek ludności stanowili tam Niemcy. Brak jednostek z tych części Węgier sprawiał, że jednostki z pozostałych części Węgier mobilizowane były na terenach o wyższym odsetku ludności węgierskiej, co sprawiało, że większy w nich mógł być procent żołnierzy narodowości węgierskiej, niż wynikało to z ogólnego składu narodowościowego państwa. A zatem twierdzenie, że ok. $60 \%$ żołnierzy załogi twierdzy stanowili Węgrzy może być uzasadnione jedynie z punktu widzenia pochodzenia jednostek Królestwa Węgierskiego, żadną jednak miarą nie może być utożsamiane z narodowością węgierską. Jeśli założyć, że wśród żołnierzy pochodzących z Królestwa Węgierskiego znalazła swe odzwierciedlenie struktura narodowościowa ówczesnych Węgier (bez Chorwacji i Siedmiogrodu), to Węgrzy stanowili zdecydowanie ponad połowę kontyngentu z ich części monarchii, trudno jednak kategorycznie określić, jaka to była część. Licząc w bardzo dużym zaokrągleniu, ludność rumuńsko- $i$ chorwackojęzyczna stanowiła ponad 22\% ludności ówczesnych Węgier. Zakładając, że jednak część jednostek walczących w Przemyślu mobilizowana była także na terenach rumuńskojęzycznych, dla równego rachunku można przyjąć tę wartość jako 20\% ogółu ludności państwa, czyli ok. 4 milionów ludzi. Odejmując to od ogólnej liczby mieszkańców Węgier, pozwalałoby to oszacować statystyczny udział Węgrów w pozostałej grupie ludności z Zalitawii na ok. 60-62\%. Jeśli ten odsetek znalazł odzwierciedlenie w strukturze narodowościowej jednostek węgierskich walczących w Twierdzy Przemyśl, to można założyć, że w ogólnej liczbie obrońców mogli oni stanowić ok. 35-36\% (stanowiłoby to ok. 46 000-47 000 w przypadku ok. 131000 żołnierzy na początku drugiego oblężenia). To sprawiałoby, że Węgry byli najliczniej reprezentowaną narodowością w Twierdzy Przemyśl.

Założyć można, że drugą co do liczebności grupą narodowościową w Twierdzy Przemyśl byli Ukraińcy, którzy dominowali w pułkach i batalionach mobilizowanych we Wschodniej Galicji (k.k. 33, 35 LstIR, k.k. 19 i 35 LIR, k.k. 35 LMarschIB) oraz stanowili znaczący odsetek w k.k. 18 LstIR oraz dwóch batalionach k.k. 34 LstIR, a także batalionach Grupy gen. Nickla, czy oddziale roboczym utworzonym na bazie k.u.k. 77 IR. Do liczby żołnierzy ukraińskich w Twierdzy Przemyśl należy też doliczyć Rusinów służących w k.u. 10 i 11 LstIR, aczkolwiek była to liczba relatywnie nieduża. Trudno też oszacować dokładną liczbę Ukraińców, którzy znaleźli się w Przemyślu jako cywilni woźnice. Założyć jednakże można, że Ukraińcy, którzy w Galicji w zdecydowanej większości byli wyznania greckokatolickiego ${ }^{175}$, stanowili znakomitą większość wśród ok. 35000 żołnierzy tej konfesji, którzy w twierdzy służyli ${ }^{176}$. W tej sytuacji stanowiliby oni przynajmniej $25 \%$ garnizonu twierdzy.

${ }^{175}$ W. Bihl, Die Ruthenen, w: Die Habsburgermonarchie 1848-1918, 3. Bd., Die Völker des Reiches, 1. Tb., hrsg. von A. Wandruszka i P. Urbanitsch, Wien 1980, s. 565-566.

${ }^{176}$ A. Szczupak, Greckokatolicka diecezja przemyska w latach I wojny światowej, Kraków 2015, s. 97. 
Wśród pozostałej części niemały był też odsetek Polaków, dominujących w k.k. 17 LstIR, ale też stanowiących znaczącą część k.k. 18 LstIR i batalionów k.k. 34 LstIR i grupy gen. Nickla, czy nawet pułków wschodniogalicyjskich. Tu ponadto Polacy stanowili zapewne niemałą część korpusu oficerskiego. W sumie liczbę Polaków w tychże jednostkach można szacować na nie mniej niż 5000. Polacy zapewne też znajdowali się w szeregu niesprecyzowanych bliżej jednostek mobilizowanych na terenie X Korpusu. Zakres geograficzny miejscowości, z których pochodzili strażacy z „Pamiętników” Krygowskiego (od Dębicy po Gródek Jagielloński), zbliżony jest właśnie do obszaru tego korpusu. Niewykluczone, że szereg rezerwistów bez określonego przydziału $\mathrm{z}$ tego terenu zostało skierowanych do Przemyśla i tu wcielano ich ad hoc do rozmaitych formacji pomocniczych służących w twierdzy. W sumie liczbę Polaków służących w Przemyślu można ocenić na przynajmniej 6000-7000.

Nieco mniejsza mogła być liczba żołnierzy rumuńskich. Prasa rumuńska monarchii po upadku Twierdzy Przemyśl podała, że znajdowało się w niej ok. 6000 żołnierzy i oficerów narodowości rumuńskiej, głównie z Banatu, komitatu Arad, okolic Orsowy ${ }^{177}$. Przy wszystkich zastrzeżeniach, jakie można mieć do danych podawanych w prasie, można stwierdzić, że owe 6000 wynosiło ok. 4,5-5\% załogi twierdzy, co stanowiło mniej niż podane wyżej 7\% żołnierzy rumuńskich w armii austro-węgierskiej, więc wydaje się, że jest to liczba prawdopodobna, a nawet zaniżona zważywszy na strukturę narodowościową terenów, na których mobilizowana była nie tylko k.u. 23 LITD i k.u. 2 LFKR, ale też k.u. 16 MarschIR.

Trudno jest oszacować liczbę żołnierzy narodowości serbskiej. Według danych dla struktury narodowościowej obszaru mobilizacyjnego k.u. 23 LITD stanowili oni prawie $12 \%$ ludności na tym terenie. Biorąc pod uwagę dane podane przez Ehnla, stanowili oni ponad $44 \%$ żołnierzy k.u. 7 LIR, czyli ok. $1 \frac{1}{2}$ batalionu, a więc teoretycznie ok. 1500 żołnierzy. Do tego trzeba doliczyć pewną część żołnierzy z k.u. 4 MarschIR i huzarów z k.u. 4 LHR oraz artylerzystów z k.u. 2 LFKR. Ostrożnie licząc, w sumie Serbowie mogli stanowić do 2000 żołnierzy.

Równie trudna do oszacowania jest liczba Słowaków. Opierając się na danych dla struktury językowej okręgów mobilizacyjnych k.u. 9, 10, 11 i 16 LIR, gdzie odsetek żołnierzy słowackich wynosił ok. $22 \%$, można założyć, że podobny był ich stosunek w pułkach pospolitego ruszenia k.u. 97 LstIBrig, a zatem ok. 2600 żołnierzy. Do tego trzeba jednak doliczyć niewiadomą, ale niewątpliwie znaczną liczbę żołnierzy oddziałów roboczych pochodzących z okolic Bratysławy i Górnych Węgier. W k.u.k. Mil.Arb.Abt. Nr. 1, 2/12, 1-3/25, 1, 2/26 i k.u. Befestigungs-Arb.Abt. 1-6/Lst. 16 mogli liczyć około 30-40\% żołnierzy, w k.u. Arb.Abt. 1-14/Lst. 13, 15-17/Lst. 13 około 50\% żołnierzy - przy założeniu, że mamy tu do czynienia w sumie z 30 kompaniami roboczymi (pomijając wspomniane wyżej wątpliwości co do liczby kompanii roboczych utworzonych

177 „Gazeta Transilvaniei”, R. 78, nr 59 z 15(28) marca 1915, s. 2. 
na bazie k.u. 13 LIR), liczącymi każda ok. 260 żołnierzy, możemy mieć tu do czynienia z kilkoma tysiącami żołnierzy.

Niemcy z pewnością dominowali w k.k. 108 LstIBrig. W sumie jednak składała się ona z dwóch pułków, co już teoretycznie nie stanowiło dużej liczebnie siły. Trzeba też mieć na uwadze, że 108 brygada w połowie września 1914 r. dotarła do Przemyśla zdziesiątkowana. Jak wspomniano, w tym czasie pułki tworzące brygadę liczyły nieco ponad 3500 żołnierzy i nawet uwzględniając uzupełnienia, to liczebność tych jednostek nie mogła w czasie walk o twierdzę być dużo wyższa. Raczej zresztą zachodził proces odwrotny - w związku ze stratami poniesionymi w listopadzie i grudniu 1914 r. pod koniec stycznia oba pułki połączono w c.k. Pułk Pospolitego Ruszenia 21/II ${ }^{178}$. Oczywiście, Niemcy w Twierdzy Przemyśl reprezentowani byli też w innych oddziałach - artylerii, formacjach technicznych i pomocniczych ${ }^{179}$, a ponadto stanowili oni w dużej mierze korpus oficerski jednostek przedlitawskich, jak również służyli w oddziałach zalitawskich, jednakże w ogólnej liczbie, aczkolwiek trudno jest tu podać jednak przybliżoną nawet wartość, z pewnością nie stanowili oni grupy, która sięgałaby odsetka $25 \%$ Niemców w całej armii austro-węgierskiej.

Podobnie rzecz się miała z Czechami, którzy mogli stanowić większość (lub raczej około połowy) tylko w k.k. 10 LstIR. W najlepszym razie dawało to niespełna 1500 żołnierzy. Nawet doliczając Czechów stanowiących kadrę oficerską i podoficerską w pozostałych przedlitawskich pułkach oraz ich obecność w innych jednostkach, to z pewnością nie ich odsetek nie sięgał pułapu 13\%, jaki stanowili Czesi w całej armii.

Przedstawiciele pozostałych narodowości monarchii - Włosi, Słoweńcy, Chorwaci - stanowili nieznaczną część garnizonu Twierdzy Przemyśl. W przypadku Słoweńców pewien obraz może dać cytowana już informacja z słoweńskiego tygodnika „Novi Čas”, który po pierwszym oblężeniu pisał o ponad tysiącu słoweńskich artylerzystów i jeszcze większej liczbie piechurów walczących w Twierdzy Przemyśs $1^{180}$.

${ }^{178}$ O. Stolz, op. cit., s. 201.

${ }^{179} \mathrm{~W}$ swym dzienniku doktor Richard v. Stenitzer wspominał, że lekarze pracujący w Szpitalu Twierdzy nr 4 w dużej mierze byli wiedeńczykami; także piekarze z piekarni polowej w VIII Obwodzie Obronnym pochodzili ze stolicy monarchii, zob. R. Stenitzer, op. cit., s. 52.

${ }^{180}$ „Novi Čas”, R. 5, nr 43 z 22 października 1914 r., s. 3. 


\section{Bibliografia}

Źródła archiwalne:

Muzeum Narodowe Ziemi Przemyskiej. Archiwum podpułkownika Eleka Molnára, Teka 3, sygn. MP-Hist. 390, k. 2; Teka 4, sygn. MP-Hist. 391, k. 81-82, 102, 103, 213, 223; Teka 7, sygn. MP-Hist. 394, k. 8.

\section{Źródła drukowane:}

A m. kir. honvédség hadrendje békében: az 1914. évi tavaszán történt helyörségváltoztatások után (lezárva 1914 április hó 1-én), Budapest 1914.

A Magyar Szent Korona Országainak 1910. évi népszámlása. 1. rész, A népesség föbb adatai. Községek és népesebb puszták, telepek szerint, Budapest 1912.

F. Conrad v. Hötzendorf, Aus meiner Dienstzeit 1906-1918, 1. Bd., Die Zeit der Annexionskrise 1906-1909, Wien 1921.

F. Conrad v. Hötzendorf, Aus meiner Dienstzeit 1906-1918, 4. Bd., 24. Juli 1914 bis 30. September 1914, Die politischen und militärischen Vorgänge vom Fürstenmord in Sarajevo bis zum Abschluß der zweiten Offensive gegen Serbien und Rußland, Wien [etc.] 1923.

F. Conrad v. Hötzendorf, Aus meiner Dienstzeit 1906-1918, 5. Bd., Oktober-November-Dezember 1914 : die Kriegsereignisse und die politischen Vorgänge in dieser Zeit, Wien 1925.

Die Ergebnisse der Volkszählung vom 31. Dezember 1910 in der Im Reichsrate Vertretenen Königreichen und Länder. 1. Heft, Die summarischen Ergebnisse der Volkszählung, Wien 1912.

Dziennik oficera Landsturmu, Przemyśl 2004.

J. Fodor, Przemyslből haza Szibérián át. I, Przemysl vedelmenek kiépitésé, „Fogadó: országos vendéglős szakközlöny”, R. 14, nr 20 z 15 października 1917, s. 2-3.

Heeres- (Marine-) Ergänzungs-Bezirks-Eintheilung, ,Verordnungsblatt für das k.k. Heer. Normal-Verordnungen", 49. Stück vom 21. Dezember 1882.

In Przemyśl Kriegsgefangene zusammengestelt nach den vom russischen Roten Kreuze eingelangten Gefangenen Listen. P4, 23 lutego 1916.

J. Jabłońska, Dziennik z oblężonego Przemyśla 1914-1915, Przemyśl 2017.

S. Kasznica i in., Najważniejsze wyniki spisu ludności i spisu zwierząt domowych wedtug stanu z d. 31 grudnia 1910 r. (Wiadomości statystyczne o stosunkach krajowych wydawane przez Krajowe Biuro Statystyczne, t. 24, z. 1), Lwów 1911.

A. Krasicki, Dziennik z kampanji rosyjskiej, Lwów 1935.

A. Kraus, Die Ursachen unserer Niederlage: Erinnerungen und Urteile aus dem Weltkrieg, München 1921.

Kriegsgliederung der Besatzung von Przemyśl zur Zeit der 2. Einschließung, w: K. Tranmer, Przemyśl 1914-1915, Wien 2003, s. 19-20.

K. Krygowski, Pamiętnik, Poznań 2016.

I. Lagzi, „...Mindnyájunknak ei kell menni...": a második przemysli magyar napló, 1914, I. rész, „Napjaink”, 1990, R. 29, nr 1, s. 21-30; II. rész, „Napjaink”, 1990, R. 29, nr 2, s. 31-39.

T. Lehoczky, Világháborúnk, I-II. rész, Beregszász-Ungvár 2016,

J. Lenar, Pamiętnik z walk o Twierdzę Przemyśl, Przemyśl 2005.

Organische Bestimmungen für die k.k. Landsturmbezirkskommandos, „Normalverodnungsblatt für das k.u.k. Heer", 5. Stück vom 1 Februar 1913.

Organische Bestimmungen für die k.k. Landwehr-(Landesschützen-) Ergänzungsbezirkskommandos, „Normalverodnungsblatt für das k.u.k. Heer”, 5. Stück vom 1 Februar 1913.

V. Mészáros, Húsz évvel ezelött... Kis epizódok a nagy háborúból, VIII, IX, Przemyśl vára az ostrom alatt, „Győri Hírlap”, R. 78, nr 244 z 28 października, s. 4-5; nr 248 z 4 listopada 1934 r., s. 4-5. 
I. Miklauzič, Kard és fátyol. Lovag Arlow Viktor ezredes Przemyśl-Vladivosztok-Györ, Budapest 2015.

V. Nerad, Przemyśl: Erinnerungen des Genieoffiziers Ing. Viktor Nerad, Salzburg 2015.

„Normalverordnungblatt für das k.u.k. Heer”, 32. Stück, vom 4 Juli 1914.

Schematismus der k.k. Landwehr und der k.k. Gendarmerie der Im Reichsrate Vertretenen Königreiche und Länder für 1912, Wien 1912.

Schematismus der k.k. Landwehr und der k.k. Gendarmerie der Im Reichsrate Vertretenen Königreiche und Länder für 1913, Wien 1913.

Schematismus für das k.u.k. Heer und für die k.u.k. Kriegsmarine für 1914, Wien 1914.

Seidels kleines Armeeschema: Dislokation und Einteilung des k.u.k. Heeres, der k.u.k. Kriegsmarine, der. k.k. Landwehr und der königlich ungarischen Landwehr (Abgeschlossen mit 5. August 1914), Wien 1914.

R. Stenitzer, Belegerung und Gefangenschaft: von Przemyśl bis Russisch Turkestan: das Kriegstagesbuch des Dr. Richard Ritter von Stenitzer 1914-1917, Graz 2010.

J. J. Stock, Notatnik z Twierdzy Przemyśl 1914-1915, Przemyśl 2014.

F. Stuckheil, Drugie oblężenie Twierdzy Przemyśl, II, Czasy upadku, Przemyśl 2004.

L. Thaisz, Honvédtüzérek Przemyślben, „Hadtörténelmi Közlemények“, t. 27 (1926), s. 480-514.

A. Trojanowski, Żotnierskie pamiętniki 1914-1918, na podstawie zapisków ustnych i przekazów opracował Władysław Trojanowski, msps udostępniony przez Martę Trojanowską.

Por. Stanisław Tyro - naoczny świadek walk o Twierdzę Przemyśl, oprac. A. Durkacz-Foremska i M. Wołk, Przemyśl 2020.

Übersicht der Aufteilung der Länder der heiligen Krone Ungarns in Landsturmkommandobereiche, „Normalverordnungblatt für das k.u.k. Heer”, 32. Stück, vom 4 Juli 1914.

„Verlustliste“, 1914-1919.

J. Vit, Wspomnienia z mojego pobytu w Przemyślu podczas oblężenia rosyjskiego 1914-1915, Przemyśl 1995.

\section{Prasa:}

„Badener Zeitung”, 1915.

„Délmagyarország”, 1914.

„Dunatúli Napló”, 1915.

„Egri Ujság”, 1918.

„Gazeta Transilvaniei”, 1915.

„Grazer Volksblatt”, 1915.

„Kiskun-Halas Helyi Értesítője”, 1916.

„Kriegsnachrichten”, 1915.

„Novi Čas”, 1914.

„Pressburger Zeitung”, 1915.

„Szamos”, 1915.

„Tábori Ujság”, 1915.

„Zala”, 1915.

\section{Opracowania:}

A magyar gyalogság. A magyar gyalogos katona története, szerk. J. Doromby, L. Reé, [Budapest, 1939].

A világháború története, szerk. J. Pilch, Budapest [1928].

A volt. $m$. kir. nagyváradi 4. honvéd gyalogezred és népfelkelö alakulatai bajtársi szövetségnének értesitöje (összeáll.) K. Kratochwil, [S.1.] 1933.

A volt m. kir. szegedi 5-ös honvédek: világháborus emlékalbuma, összeáll. B. Réti, Szeged 1933. 
K. Aggházy, S. Valér, A világháború: 1914-1918, Budapest 1934.

M. Baczkowski, Pod czarno-żóttymi sztandarami: Galicja i jej mieszkańcy wobec austro-wegierskich struktur militarnych 1868-1914, Kraków 2003.

T. Balla i in., The history of the Hungarian artillery 1913-2013, Budapest cop. 2015.

T. Balla, A magyar királyi Honvéd Tüzérség 1912-1914. I. rész, w: „Hadtorténelmi Közlemények”, R. 106, z. 3 (1993), s. 18-44.

T. Balla, A magyar királyi Honvéd Tüzérség 1912-1914, II. rész, „Hadtorténelmi Közlemények”, R. 106, z. 4 (1993), 43-75.

T. Balla, A militarista birodalom mitosza: az osztrák-magyar haderő az elsö világháború elöestéjén, w: Hadtorténelmi Közlemének, R. 127, z. 3 (2014), s. 628-645.

W. Bihl, Die Juden, w: Die Habsburgermonarchie 1848-1918, 3. Bd., Die Völker des Reiches, 2. Tb., hrsg. von A. Wandruszka, P. Urbanitsch, Wien 1980, s. 890-948.

W. Bihl, Die Ruthenen, w: Die Habsburgermonarchie 1848-1918, 3. Bd., Die Völker des Reiches, 1. Tb., hrsg. von A. Wandruszka, P. Urbanitsch, Wien 1980, s. 555-584.

Á. Biró i in., Wegierskie Lwy Judy w Galicji: katalog wystawy, Kraków 2017.

Budapest volt házi ezredének a cs. és kir. 32. gyalogezrednek története (1741-1918), szerk. S. Tinódi Varga, [Budapest 1930].

W. Daniec, Pamiętnik z przeżyć wielkiej wojny [Cz.1], Rzeszów 1925.

Debreceni honvédek harcban, I. rész, A m. kir. debreceni 3. honvéd gyalogezred harcai az oroszokkal az olasz hadüzenetig, összeall. J. Molnár, Debrecen 1926.

Der Heldenweg des Zweier-Landsturm 1914-1918: Geschichte des oberösterreichisch-salzburgischen k.k. Landsturm-Infanterieregiments Nr. 2 und der selbständigen Landsturm-Feldbataillone, Linz [1937].

Erdélyi ezredek a világháborúban, szerk. L. Dezseő, Budapest [1941].

M. Ehnl, Die österreichisch-ungarische Landmacht nach Aufbau, Gliederung, Friedensgarnison, Einteilung und nationaler Zusammensetzung im Sommer 1914, Wien 1934.

B. Fábián, 6 ló - 40 ember: hadifogoly feljegyzések, Budapest [1930].

J. Ferenc, Przemyśl, „Magyarság”, R. 10, nr 100 z 4 maja 1929, dodatek, s. III.

O. Firbás, Przemyśl szegedi védői [I], „Szegedi Szemle”, R. 3, nr 9 (83) z 27 marca 1930, s. 2-4.

F. Forstner, Twierdza Przemyśl, Warszawa 2000.

J. Gabányi, Magiera (Részlet a 7. honvéd gyalogezred naplójából), „Hadtörténelmi Közlemények”, t. 28 (1927), s. 561-571.

B. Geőcze, A przemysli tragédia, Budapest 1922.

W. Gorgosz, Oblężenie i obrona Przemyśla wr. 1914/1915, Odbitka z „Bellony” t. 41, Warszawa 1933.

K. Grzybowski, Historia państwa i prawa Polski, t. 4, Od uwłaszczenia do odrodzenia państwa, Warszawa 1982.

H. Heiden, Bastion nad Sanem: losy Twierdzy Przemyśl, Oświęcim 2013.

L. Katus, Die Magyaren, w: Die Habsburgermonarchie 1848-1918, 3. Bd., Die Völker des Reiches,

1. Tb., hrsg. von A. Wandruszka i P. Urbanitsch, Wien 1980, s. 410-488.

F. Kepes, 1. honvéd gyalogezred története és háborús emlékalbuma, Budapest 1939.

G. Kolmer, Parlament und Verfassung in Österreich, Vol. 4, 1885-1891, Wien-Leipzig 1907.

Magyarország története a 19. században, szerk. A. Gergely, Budapest 2005.

J. Lévai, Éhség, árulás, Przemyśl, Budapest 1933.

D. Molnár, Limanova: magyar gyözelem, Budapest 1932.

K. Molnár, Magyar élet és magyar irodalom Przemyslben 1914-1915 [I. rész], „Egri Népujság“, R. 41, nr 49 z 28 lutego 1924 r., s. 1-2.

Négyes honvédek fegyverben, [Békéscsaba 1934].

S. Nielipowicz, Krwawy październik 1914, t. 2, Oświęcim 2015.

D. Nónay, A volt m. kir. szegedi 5. honvéd gyalogezred a világháborúban, Szeged 1931. 
T. Nowakowski, Armia austro-węgierska 1909-1918, Warszawa 1992.

Österreich-Ungarns letzter Krieg, 1. Bd. Das Kriegsjahr 1914: Vom Kriegsausbruch bis zum Ausgang der Schlacht bei Limanowa-Lapanów, hrsg. von E. Glaise-Horstenau, 2. Aufl., Wien 1931.

Österreich-Ungarns letzter Krieg, 2. Bd., Das Kriegsjahr 1915, 2. Teil, Beilagen, Wien 1931.

T. Papp, A magyar honvédség megalakulása a kiegyezés után, I. rész, w: Hadtörténelmi Közlemények, R. 14, z. 2 (1967), 688-771.

A. Płomieńczyk [pseud.], Armja austro-wegierska, Warszawa 1916.

M. Rauchensteiner, The First World War and the end of Habsburg Monarchy: 1914-1918, Wien [etc.] 2014.

K. Révy, Przemysl feladata és szerepe 1915. márc. 22-ig, „Magyar Katonai Közlöny“, R. 8, nr 6 (1920), s. 381-389;

idem, Tamásy Árpád táborszernagy 1861-1939, „Magyar Katonai Szemle“, R. 9, 3 (1939), s. 237-239.

O. Stolz, Das Tiroler Landsturmregiment Nr. II im Kriege 1914-15 in Galizien, „Veröffentlichungen des Museums Ferdinandeum", 18. Bd. (1938), s. 129-222.

A. Szczupak, Greckokatolicka diecezja przemyska w latach I wojny światowej, Kraków 2015.

B. Świętojańska, Miasto Przemyśl garnizonem armii austro-węgierskiej w okresie autonomii galicyjskiej, „Rocznik Przemyski“, R. 40 (2004), z. 4 Historia, s. 32.

G. A. Thunstall, Written in blood: the battles for fortress Przemyšl, Bloomington \& Indianapolis 2016.

A. Watson, The fortress: the great siege of Przemyśl, London 2019.

W. Włoskowicz, Nazwy austro-wegierskich jednostek wojskowych. Studium polityki nazewniczej z zakresu chrematonimii wojskowej, „Onomastica”, R. 64 (2020), s. 121-148. 